\title{
Advances in Prognostic Methylation Biomarkers for Prostate Cancer
}

\author{
Dilys Lam ${ }^{1}$, Susan Clark ${ }^{1,2}$ (), Clare Stirzaker ${ }^{1,2,+}+\mathbb{D}$ and Ruth Pidsley ${ }^{1,2, *,+}$ \\ 1 Epigenetics Research Laboratory, Genomics and Epigenetics Division, Garvan Institute of Medical Research, \\ Sydney, New South Wales 2010, Australia; d.lam@garvan.org.au (D.L.); s.clark@garvan.org.au (S.C.); \\ c.stirzaker@garvan.org.au (C.S.) \\ 2 St. Vincent's Clinical School, University of New South Wales, Sydney, New South Wales 2010, Australia \\ * Correspondence: r.pidsley@garvan.org.au; Tel.: +61-2-92958315 \\ + These authors have contributed equally.
}

Received: 22 September 2020; Accepted: 13 October 2020; Published: 15 October 2020

check for updates

Simple Summary: Prostate cancer is a major cause of cancer-related death in men worldwide. There is an urgent clinical need for improved prognostic biomarkers to better predict the likely outcome and course of the disease and thus inform the clinical management of these patients. Currently, clinically recognised prognostic markers lack sensitivity and specificity in distinguishing aggressive from indolent disease, particularly in patients with localised, intermediate grade prostate cancer. Thus, there is major interest in identifying new molecular biomarkers to complement existing standard clinicopathological markers. DNA methylation is a frequent alteration in the cancer genome and offers potential as a reliable and robust biomarker. In this review, we provide a comprehensive overview of the current state of DNA methylation biomarker studies in prostate cancer prognosis. We highlight advances in this field that have enabled the discovery of novel prognostic genes and discuss the potential of methylation biomarkers for noninvasive liquid-biopsy testing.

\begin{abstract}
There is a major clinical need for accurate biomarkers for prostate cancer prognosis, to better inform treatment strategies and disease monitoring. Current clinically recognised prognostic factors, including prostate-specific antigen (PSA) levels, lack sensitivity and specificity in distinguishing aggressive from indolent disease, particularly in patients with localised intermediate grade prostate cancer. There has therefore been a major focus on identifying molecular biomarkers that can add prognostic value to existing markers, including investigation of DNA methylation, which has a known role in tumorigenesis. In this review, we will provide a comprehensive overview of the current state of DNA methylation biomarker studies in prostate cancer prognosis, and highlight the advances that have been made in this field. We cover the numerous studies into well-established candidate genes, and explore the technological transition that has enabled hypothesis-free genome-wide studies and the subsequent discovery of novel prognostic genes.
\end{abstract}

Keywords: DNA methylation; epigenetics; biomarkers; circulating DNA; cfDNA; prostate cancer; early detection; prognosis

\section{Introduction}

Prostate cancer $(\mathrm{PCa})$ is the most commonly diagnosed noncutaneous cancer in men and one of the leading causes of cancer death in males. Globally, 1,276,106 new cases were diagnosed in 2018 alone [1,2], and this number is projected to rise by approximately $80 \%$, to more than two million new cases a year, by 2040 [3-5]. Currently, PCa diagnosis is achieved through assessment of blood prostate-specific antigen (PSA) levels, digital rectal examination (clinical T-stage) and histological examination of needle 
biopsies (Gleason Score (GS)/ISUP Grade) [6]. PSA-based screening was introduced in the late 1980s, and has significantly increased the early detection of localized disease [7-9]. Diagnosis at this early organ-confined stage of disease is crucial as it is potentially curable by radical prostatectomy (RP), a procedure to surgically remove the whole prostate gland. While this is curative for most prostate cancers, approximately $30 \%$ of patients treated by RP experience biochemical recurrence (BCR) [10], and $17-22 \%$ of these relapsed patients progress to metastatic-lethal PCa [11-13]. There is therefore a need to identify the men at high risk of metastatic progression, so that additional interventions can be offered earlier (e.g., adjuvant therapies such as chemotherapy and radiotherapy) [14].

On the other hand, many men diagnosed with PCa have an indolent form of the disease, which is characterised by slow progression with no eventual clinical manifestation $[15,16]$. For these men, $\mathrm{RP}$ represents an overtreatment given the risk of unnecessary side effects and compromised quality of life $[17,18]$. Thus, strategies such as 'watchful waiting' and 'active surveillance' have emerged for men diagnosed with low grade disease, in which regular monitoring is used to detect tumour progression, with the aim of delaying RP until it is clinically necessary [19]. However, $13-45 \%$ of low-risk men on active surveillance exhibit a PSA rise and progress to surgery or other treatments [20-22], indicating that they may have been inappropriately assigned to monitoring, and should have been treated earlier.

PCa has a heterogeneous clinical course which makes it challenging to decide the most appropriate treatment or monitoring strategy for individual patients [23]. There is a major unmet clinical need for specific prognostic biomarkers that can accurately differentiate indolent from aggressive tumours that are likely to metastasise and lead to lethal disease [24]. The ability to identify the risk of progression at initial diagnosis would inform decisions about personalized treatment and/or monitoring strategies, as well as the use of adjuvant therapy, for improved clinical management and enhanced outcomes for PCa patients (Figure 1).

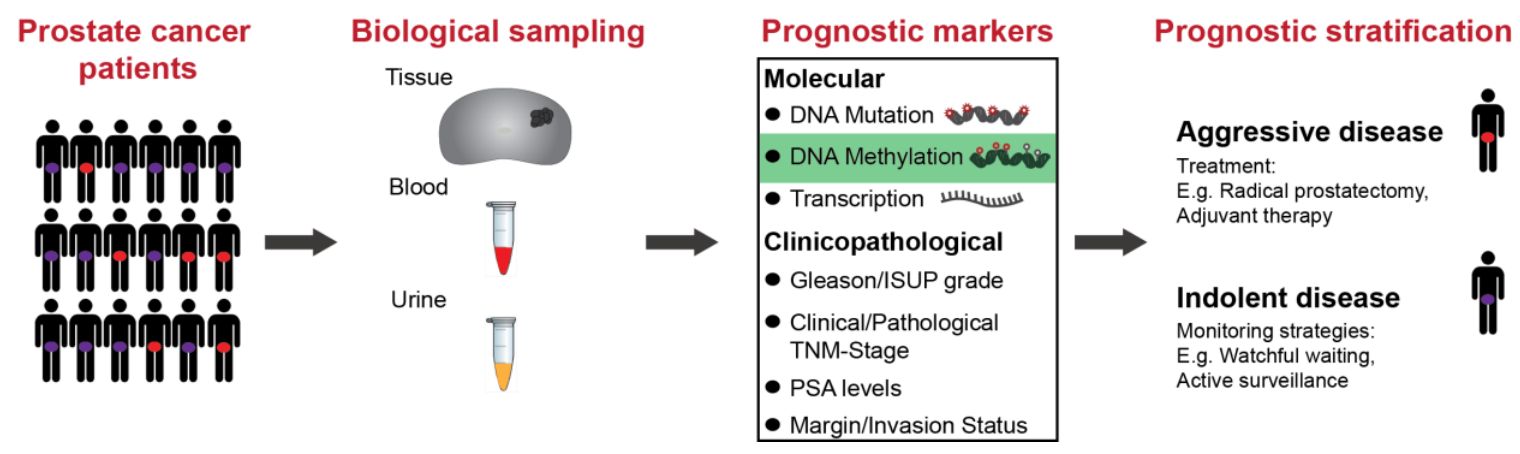

Figure 1. Schematic showing the pathway for the application of biomarkers for improved prognostic stratification in prostate cancer patients. Prostate cancer is a heterogeneous disease and identifying those patients at diagnosis that have aggressive vs. indolent disease is critical in informing the clinical management of these patients. Biological sampling includes tissue biopsies, and blood and urine samples. These are assayed using molecular biomarkers, including DNA mutations, DNA methylation and transcription, and clinicopathological markers, such as GS/ISUP grade and tumour staging. The ultimate goal is to improve the prognostic stratification of patients to inform the optimal treatment strategies for prostate cancer patients. TNM: tumour/nodes/metastasis staging; PSA: prostate-specific antigen.

\subsection{Current Clinicopathological Prognostic Markers}

The existing scoring systems and nomograms that are used to identify patients at high risk of progression are based solely on routine clinical and pathological variables at the time of diagnosis or surgery, including preoperative (pre-op) PSA levels, GS/ISUP grade scoring, tumour staging (clinical or pathological T-stage) and margin status (Figure 1) [11,25-30]. These tools, whilst useful in the diagnostic assessment of the tumour, lack sensitivity and specificity in classifying the risk of an individual patient's disease [6,31-33]. One problem with the current prognostic approach 
is that a number of scoring systems exist, with no single accepted standard system being used in clinical practice $[29,34]$. Furthermore, these prognostic variables are based on histological assessment, which may not capture the underlying biology of a tumour and its potential to progress to an aggressive, lethal cancer. Advances in molecular profiling techniques mean that we can now access another layer of biological information in tumours, including early molecular changes that may precede histologically visible alterations [23,35]. Much research is now being dedicated to investigating whether molecular information can better inform clinical decisions about individualised treatment and/or monitoring strategies, as well as providing new biological insights to guide the development of new therapies [35].

\subsection{Molecular Biomarkers for Prognosis}

There is increasing evidence for the value of prognostic molecular biomarkers to complement existing standard clinicopathological markers. Molecular prognostication of PCa has been investigated in various contexts, including at the level of genetic, epigenetic and gene expression alterations [36,37], from both tumour tissue $[37,38]$ and liquid biopsies $[39,40]$ (Figure 1). To date, the major success stories of prognostic molecular biomarkers are the commercialised tissue-based tests centred on panels of gene expression signatures. These tests include Prolaris (Myriad Genetics, Salt Lake City, UT, USA), Oncotype DX Prostate (Genomic Health, Redwood City, CA, USA) and Decipher (GenomeDX Biosciences, Vancouver, BC, Canada) [37]. The Prolaris test determines risk of progression (BCR, cancer-specific death) by measuring a proliferation signature of 31 cell cycle progression transcripts [41], whilst Oncotype DX predicts adverse pathology (high grade/stage disease) or poor outcome (BCR) based on 12 genes [42]. Decipher is based on 22 markers which have been trained to predict early metastasis and aggressive PCa [43]. Whilst these tests demonstrate the potential for molecular biomarkers, they have yet to be integrated into the standard clinical routine following the initial diagnosis [37].

\subsection{DNA Methylation Biomarkers}

DNA methylation is one of the earliest, most stable and frequent alterations in the cancer genome and has been extensively investigated as a source of molecular biomarkers [36,44-46]. DNA methylation is an epigenetic modification, in which a methyl group is added to the cytosine base of a cytosine-guanine $(\mathrm{CPG})$ dinucleotide. It is associated with gene regulation and function, with promoter-associated clusters of marks, termed CpG islands, often linked to gene silencing [47,48]. In the context of $\mathrm{PCa}$, aberrant DNA methylation is a key feature observed during early tumorigenesis, as well as in its progression and metastatic development [49-51], and occurs at a much higher frequency and more consistently than genetic mutations [52]. Additionally, DNA methylation has been shown to outperform gene expression in detecting cancer from prostate biopsies [53]. The feasibility of using DNA methylation as a biomarker is further supported by the fact that DNA is more stable than RNA [54] and its methylation patterns are retained following long-term storage of clinical material, including as formalin-fixed paraffin-embedded tissue (FFPET). DNA methylation assays can also be easily integrated into routine clinical practice as many diagnostic labs already have the infrastructure in place, due to their similarity with DNA-sequence-based biomarker approaches [55]. There is currently one validated epigenetic test commercially available, ConfirmMDx (MDxHealth, Irvine, CA, USA), designed for diagnostic rather than prognostic purposes, that uses the methylation profile of three genes (APC, RASSF1, GSTP1) to detect cancer in histologically negative biopsies [56]. PCa-derived aberrant DNA methylation patterns have also been detected in liquid biopsies such as blood and urine samples, paving the way for the development of noninvasive molecular tests [57-60].

\section{Current State of Prognostic Methylated Biomarkers}

A plethora of studies have been conducted over the last two decades investigating DNA methylation-based biomarkers to aid PCa prognosis. The majority of these studies have interrogated primary prostate tumours extracted from RP tissue, whilst others have used prostate tissue from core or 
needle biopsies, transurethral resection of the prostate (TURP) specimens, as well as tumour-adjacent and benign nonneoplastic prostate specimens. The studies reviewed in this section have been primarily performed on RP tissue, and studies that have used other types of prostate specimens will be noted accordingly. Initial studies in this field, limited by the laboratory techniques available, took the traditional a priori approach of examining genes that had been implicated in biological pathways of PCa. These studies used targeted methylation profiling techniques including methylation-specific PCR (MSP) [61], quantitative methylation-specific PCR (qMSP) [62], pyrosequencing [63,64] and mass spectrometry (MassARRAY EpiTYPER, Agena Bioscience, San Diego, California, USA) [65] to assess the methylation profile of a specific gene of interest (Figure 2). Figure 2 lists other targeted approaches that have also been used to assess methylation in cancer, including ddPCR [66], COBRA [67], high resolution melt curve [68] and headloop MSP [69-71]. With recent advances in the technological capabilities to interrogate the methylome more broadly, the field has transitioned into conducting hypothesis-free genome-wide screens for novel prognostic methylation biomarkers. The candidate and genome-wide studies reviewed below use a range of outcome measures to assess the prognostic value of methylated genes, including low vs. high grade cancers, localised vs. advanced disease, and clinical outcomes such as BCR, metastatic relapse and PCa-specific death (PCa death). Importantly, the clinical outcome most often studied is BCR, defined by an increase in serum PSA levels post-RP. However, there is increasing evidence that BCR is not a sufficient indicator of progression to aggressive lethal disease, with metastatic relapse instead being the clinically relevant endpoint for predicting survival [72,73]. This requires long-term follow-up ( $\geq 15$ years) for metastatic relapse and PCa death to manifest [16], which many study populations lack, thus reducing their ability to fully evaluate and assess molecular biomarkers of PCa prognosis.

A

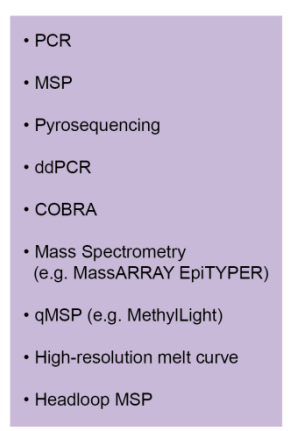

B

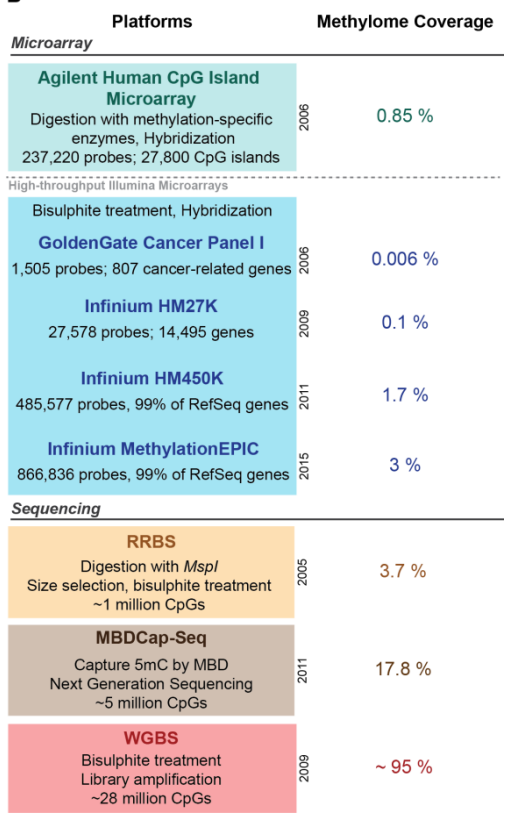

Figure 2. Methylation profiling approaches for biomarker discovery and validation. (A) Candidate gene approaches: Targeted candidate gene approaches used in a priori studies and for the validation of novel candidate markers. (B) Genome wide approaches: Microarray and sequencing-based genome-wide approaches used for the discovery of novel biomarkers - comparison of the methodology, number of CpGs (cytosine-guanine dinucleotides) and/or genes targeted and coverage of the methylome across the different platforms. RefSeq: Reference Sequences; PCR: polymerase chain reaction; MSP: methylation-specific PCR; ddPCR: droplet digital PCR; COBRA: combined bisulphite restriction analysis; qMSP: quantitative methylation-specific PCR; HM: human methylation; RRBS: reduced representation bisulphite sequencing; MBDCap-Seq: methyl-CpG binding domain capture sequencing; WGBS: whole genome bisulphite sequencing. 


\subsection{Candidate (A Priori) Markers}

To date, DNA methylation of over 60 candidate genes has been investigated. To summarise the top candidate markers with the greatest prognostic evidence, this review focuses on genes that have been investigated in at least three studies and used well-defined prognostic outcomes. The studies reporting on these genes are detailed in Table 1. The majority of these studies were performed on RP-derived tissue, when other types of tissue were used (for example, needle biopsies of prostate tissue or urine) this is specified below or within Table 1. Figure 3 visualises the 20 genes examined in these studies and specifies which of these were found to have potential prognostic value in univariate (U) and/or multivariate (M) statistical models (adjusted for clinicopathological variables) of prognosis. Below we discuss the genes that have been most extensively studied and validated across independent studies: GSTP1, APC, RARB, PITX2, CCND2 and PTGS2.

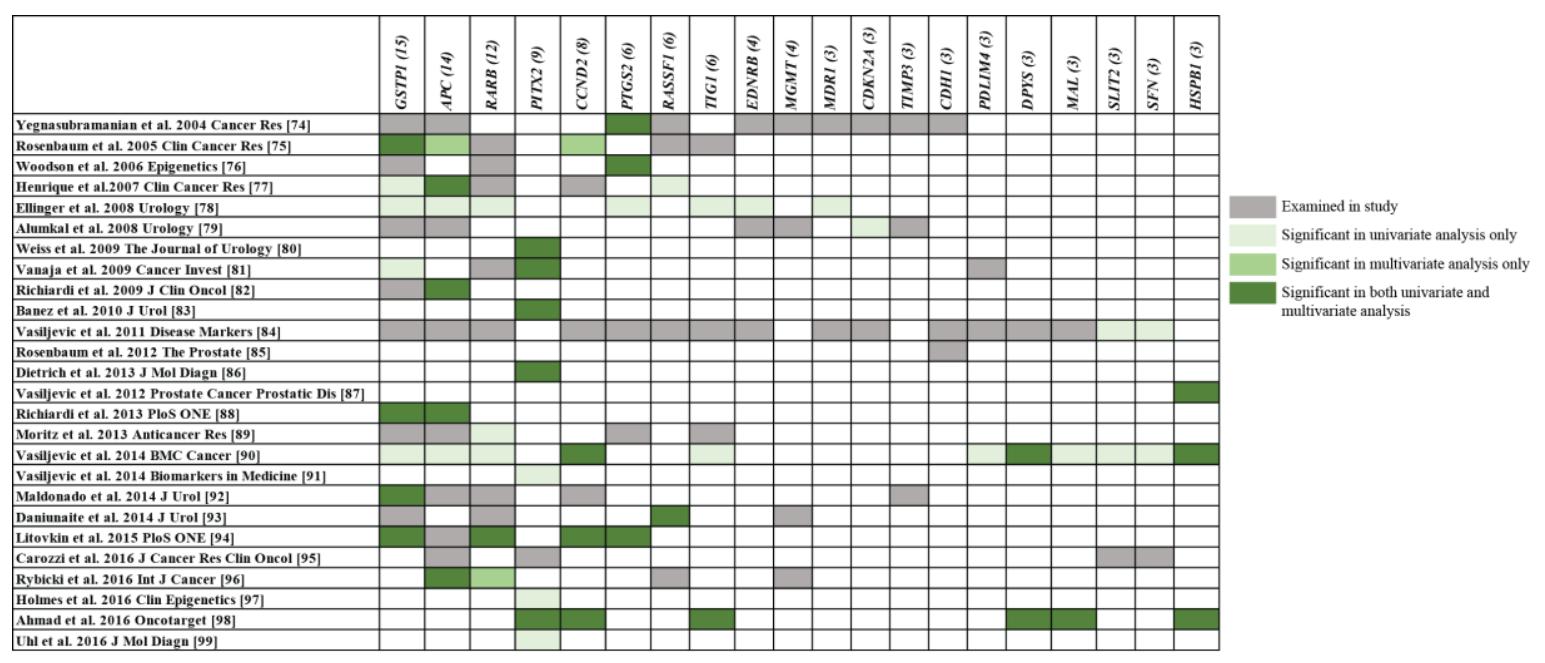

Figure 3. Genes studied in $\geq 3$ prognostic candidate marker studies. Each row represents a candidate gene study, and each column represents a gene for which three or more studies have investigated its methylation profile as a prognostic marker of PCa. The number in brackets indicates the number of studies the gene has been examined in. For each of the 26 studies, genes that were investigated have been highlighted: grey = examined in study but no significant associations were found; faded green = significant associations found in univariate analysis only; light green = significant associations observed in multivariate analysis only; green = significant associations reported in both univariate and multivariate analysis. 
Table 1. Candidate (a priori) prognostic methylated tissue-based biomarker studies.

\begin{tabular}{|c|c|c|c|c|c|c|c|c|}
\hline Study [Ref $]^{a}$ & Primary Outcomes Examined & $\begin{array}{l}\text { Total COHORT } \\
\text { SIZE }\end{array}$ & Additional COHORT DETAILS & $\begin{array}{l}\text { Follow-Up } \\
\text { (Years) }\end{array}$ & Method & Genes Examined & Genes Validated b,c,de & Results $\mathrm{g}$ \\
\hline Yegnasubramanian et al. [74] & BCR & $n=36$ & $n=\mathrm{ns} \mathrm{BCR}$ & Range: $8-13$ & qMSP & $\begin{array}{c}\text { GSTP1, APC, } \\
\text { RASSF1, PTGS2, } \\
\text { MDR1, HIC1, } \\
\text { EDNRB, ESR1, } \\
\text { CDKN2a, CDKN2b, } \\
\text { p14/QRF, MGMT, } \\
\text { hMLH1, TIMP3, } \\
\text { DAPK1, CDH1 }\end{array}$ & $\begin{array}{c}\text { U: PTGS2 } \\
\text { M: PTGS2 [+ GS + pathological } \\
\text { T-stage] }\end{array}$ & $\begin{aligned} \text { U: HR } 2.82(1.07-7.44), p & =0.04 \\
\text { M: HR } 4.26(1.36-13.36), p & =0.01\end{aligned}$ \\
\hline Rosenbaum et al. [75] & $\begin{array}{l}\text { Primary: Progression } \\
\text { Secondary: Metastatic relapse } \\
\text { and/or PCa death }\end{array}$ & $n=74$ & $\begin{array}{c}n=37 \text { no progression, } \\
n=37 \text { progression } \\
(n=14 \mathrm{BCR}, \\
n=16 \text { metastatic relapse, } \\
n=7 \mathrm{PCa} \text { death) } \\
\text { [all GS } 7(3+4)]\end{array}$ & $\begin{array}{c}\text { Min: } 7 \text {, Median: } \\
9\end{array}$ & qMSP & $\begin{array}{l}\text { APC, CCND2, } \\
\text { GSTP1, TIG1, } \\
\text { RASSF1, RARB }\end{array}$ & $\begin{array}{c}\text { Progression: } \\
\text { U: GSTP1 } \\
\text { M: [+ age > 60] (1) GSTP1+ } \\
\text { APC; (2) GSTP1 + APC and/or } \\
\text { CCND2 } \\
\text { Metastatic relapse and/or PCa } \\
\text { death: } \\
\text { U: None } \\
\text { M: None }\end{array}$ & $\begin{array}{c}\text { Progression: } \\
\text { U: HR 0.34 (0.13-0.88), } p=0.03 \\
\text { M: (1) GSTP1 [HR 0.23 (0.09-0.64), } \\
p=0.004], A P C[\mathrm{HR} 3.0(1.42-6.32), \\
p=0.004 ; \text {, (2) GSTP1 [HR 0.29 } \\
(0.11-0.77), p=0.01], A P C \text { or } \\
\text { CCND2 methylated: [HR 1.84 } \\
\text { (0.92-3.72), } p=0.09 \text { ], APC + } \\
\text { CCND2 [HR 4.33 (1.52-12.33), } \\
p=0.01] \\
\text { Metastatic relapse and/or PCa } \\
\text { death: } \\
\text { U: non-sig; M: non-sig }\end{array}$ \\
\hline Woodson et al. [76] & BCR & $n=60$ & $n=49$ no BCR, $n=11 \mathrm{BCR}$ & $\begin{array}{l}\text { Mean (SD): } \\
\text { No BCR-6.5 (3.2) } \\
\text { BCR-4.7 (2.8) }\end{array}$ & qMSP & $\begin{array}{l}\text { GSTP1, RARB, } \\
\text { CD44, PTGS2 }\end{array}$ & $\begin{array}{c}\text { U: (1) CD44; (2) PTGS2 } \\
\text { M: CD44 + PTGS2 [+ GS] }\end{array}$ & $\begin{array}{c}\text { U: (1) OR } 6.83(1.67-27.99), \\
p=0.008 ;(2) \text { OR } 4.38(1.13-17.40), \\
p=0.04 \\
\text { M: CD44+ PTGS2 [OR 8.87 } \\
(1.85-42.56), p=0.006]\end{array}$ \\
\hline Henrique et al. [77] & $\begin{array}{l}\text { Primary: PCa death } \\
\text { Secondary: BCR }\end{array}$ & $n=83$ & $\begin{array}{c}n=15 \text { PCa death } \\
n=37 \text { BCR } \\
\text { [Sextant biopsy cores] }\end{array}$ & $\begin{array}{l}\text { Median (range): } \\
\quad 3.7(0.5-5)\end{array}$ & qMSP & $\begin{array}{l}\text { APC, CCND2, } \\
\text { GSTP1, RARB, } \\
\text { RASSF1 }\end{array}$ & $\begin{array}{c}\text { PCa death: } \\
\text { U: APC } \\
\text { M: APC [+ Clinical T-stage] } \\
\text { BCR: } \\
\text { U: (1) AC; (2) GSTP1; (3) } \\
\text { RASSF1 } \\
\text { M: APC [+ Clinical T-stage] }\end{array}$ & $\begin{array}{c}\text { PCa death: } \\
\text { U: Log-rank } p=0.010 \\
\text { M: OR } 3.51 \text { (1.23-9.96), } p=0.018 \\
\text { BCR: } \\
\text { U: } \log \text {-rank (1) } p=0.002 ; \\
\text { (2) } p=0.047 ;(3) p=0.019 \\
\text { M: OR } 2.58 \text { (1.29-5.16), } p=0.008\end{array}$ \\
\hline Ellinger et al. [78] & $\mathrm{BCR}$ & $n=41$ & $\begin{array}{c}n=28 \mathrm{no} \mathrm{BCR} \\
n=13 \mathrm{BCR}\end{array}$ & $\begin{array}{l}\text { Mean; median } \\
\text { (range): } 2.3 ; 1.7 \\
(0.5-6)\end{array}$ & qMSP & $\begin{array}{l}\text { Annexin } 2, \text { APC, } \\
\text { EDNRB, GSTP1, } \\
\text { PTGS2, MDR1, } \\
\text { RARB, Reprimo, } \\
\text { TIG1 }\end{array}$ & $\begin{array}{c}\mathrm{U}:(1) A P C+\text { Reprimo, (2) }>5 \\
\text { genes hypermethylated } \\
\text { together } \\
\text { M: None }\end{array}$ & $\begin{array}{l}\text { U: Log-rank (1) } p=0.0078 \\
\text { (2) } p=0.0074 \\
\text { M: non-sig }\end{array}$ \\
\hline Alumkal et al. [79] & $\mathrm{BCR}$ & $n=151$ & $\begin{array}{c}n=104 \mathrm{no} B C R \\
n=47 \mathrm{BCR}\end{array}$ & At least 5 years & $\begin{array}{l}\text { Nested } \\
\text { MSP }\end{array}$ & $\begin{array}{l}\text { GSTP1, MGMT, } \\
\text { ASC, D DNNNA, } \\
\text { EDNRB, CDH13, } \\
\text { CD44, TIMP3, } \\
\text { RUNX3, APC, } \\
\text { WIF1- }\end{array}$ & $\begin{array}{c}\text { U: } C D K N 2 A \\
\text { M: } C D H 13 \text { and/or } A S C \text { [+ GS + } \\
\text { extra capsular penetration + } \\
\text { seminal vesicle involvement } \\
\text { +margin status] }\end{array}$ & $\begin{array}{c}\text { U: OR } 0.43(0.19-0.98), p=0.05 \\
\text { M: CDH13 [OR } 5.51(1.34-22.67) \\
p=0.02], \text { CDH13 and/or ASC [OR } \\
5.64(1.47-21.7), p=0.01, \text { sensitivity } \\
\quad=72.3 \%, \text { specificity }=48 \%]\end{array}$ \\
\hline
\end{tabular}


Table 1. Cont

\begin{tabular}{|c|c|c|c|c|c|c|c|c|}
\hline Study $[\operatorname{Ref}]^{a}$ & Primary Outcomes Examined & $\begin{array}{l}\text { Total COHORT } \\
\text { SIZE } \\
\end{array}$ & Additional COHORT DETAILS & $\begin{array}{c}\text { Follow-Up } \\
\text { (Years) }\end{array}$ & Method & Genes Examined & Genes Validated $b^{b, c, d, e}$ & Results $\mathrm{g}$ \\
\hline Weiss et al. [80] & $\mathrm{BCR}$ & $n=605$ & $\begin{array}{c}n=540 \text { no BCR } \\
n=65 \mathrm{BCR}\end{array}$ & Median: 5.5 & qMSP & $\begin{array}{c}\text { ABHD9, Chr3-EST, } \\
\text { GPR7, HIST2H 2B F, } \\
\text { CCND2, PITX2 }\end{array}$ & $\begin{array}{c}\text { U: (1) ABHD9; (2) Chr3-EST; (3) } \\
\text { GPR7; (4) HIST2H 2B F; (5) } \\
\text { PITX2 (also in GS7 only and } \\
\text { GS8 only patients) } \\
\text { M: PITX2 [+ GS + pathological } \\
\text { T-stage] }\end{array}$ & $\begin{array}{c}\text { U: (1) HR 1.9 (1.1-3.1), } p=0.02 ; \text { (2) } \\
\text { HR 2.1 }(12-3.5), p=0.007 ; \\
\text { (3) HR 2.3 (1.4-3.9), } p=0.002 ; \\
\text { (4) HR 1.9 (1.1-3.1), } p=0.018 ; \\
\text { (5) HR 3.4 (1.9-6.0), } p<0.001 \text {, GS7 } \\
\text { log-rank } p=0.007, \text { GS8 log-rank } \\
p=0.023 \\
\text { M: HR 2.5 (1.1-5.8), } p=0.032\end{array}$ \\
\hline Vanaja et al. [81] & Recurrence within 5 years & $n=64$ & $\begin{array}{c}n=32 \text { no recurrence, } \\
n=32 \text { recurrence } \\
(n=10 \mathrm{BCR}, \\
n=10 \text { local, } \\
n=12 \text { metastatic relapse })\end{array}$ & Range: $0-5$ & $\begin{array}{l}\text { MassARRAY } \\
\text { EpiTYPER }\end{array}$ & $\begin{array}{l}\text { FLNC, EFS, ECRG4, } \\
\text { Y RARB, PITX2, } \\
\text { GSTP1, PDLIM4, } \\
\text { KCNMA1 }\end{array}$ & $\begin{array}{c}\text { U: (1) FLNC (6 CpG units), (2) } \\
\text { GSTP1 (3 CpG units), (3) PITX2 } \\
\text { (1 CpG unit), (4) EFS (1 CpG } \\
\text { unit) (5) Methylation score: top } \\
\text { 11 CpG units from FLNC, EFS, } \\
\text { PITX2, PDLIM4, KCNMA1 } \\
\text { (also subgroups of patients } \\
\text { with local recurrence, } \\
\text { metastatic relapse and BCR) } \\
\text { M: Methylation score [+p re-op } \\
\text { PSA + GPSM prognostic score } \\
\text { using weighted sum of GS, } \\
\text { PSA, seminal vesicle } \\
\text { involvement and marginal } \\
\text { status] }\end{array}$ & $\begin{array}{c}\text { U: (1) Sensitivity }= \\
\text { 71.43-78.57\%//Specificity = } \\
62.52-75.12 \% ;(2) \\
63.33-76.92 \% / 72.73-81.82 \% ; \\
\text { (3) } 66.67 \% / 64.29 \% ; \\
\text { (4) } 62.50 \% / 60.02 \% ;(5) \\
71.12 \% / 71.90 \% ; \text {; local recurrence } \\
\text { only: } 80.32 \% / 21.2 \% \text {; metastatic } \\
\text { relapse only: } 72.72 \% / 75.14 \% ; \text { BCR: } \\
60.26 \% / 59.42 \% \\
\text { M: Sensitivity }=80 \% \text {, } \\
\text { Specificity }=81.2 \%, \text { AUC } 0.852\end{array}$ \\
\hline Richiardi et al. [82] & PCa death & $\begin{array}{l}\text { 1980s cohort: } \\
n=216 \\
\text { 1990s cohort: } \\
n=243\end{array}$ & $\begin{array}{l}\text { 1980s cohort: } \\
n=95 \text { no PCa death, } \\
n=121 \text { PCa death } \\
1990 \text { s cohort: } \\
n=167 \text { no PCa death } \\
n=76 \text { PCa death }\end{array}$ & $\begin{array}{c}\text { Median (range): } \\
1980 \mathrm{~s} \\
\text { cohort-3.1 } \\
(0-14) \\
1990 \mathrm{~s} \\
\text { cohort-6.3 } \\
(0-14)\end{array}$ & MSP & $\begin{array}{c}\text { APC, RUNX3, } \\
\text { GSTP1 }\end{array}$ & $\begin{array}{c}\text { 1980s cohort: } \\
\text { U: APC } \\
\text { M: APC [+ source of tumour } \\
\text { tissue + GS + follow-up } \\
\text { duration] } \\
\text { 1990s cohort: } \\
\text { U: (1) APC, (2) RUNX3 } \\
\text { M: [+ source of tumour tissue + } \\
\text { GS + follow-up duration] }(1) \\
\text { APC; (2) APC (GS }<8 \text { only); (3) } \\
\text { RUNX3; (4) RUNX3 (GS }<8 \\
\text { only) }\end{array}$ & $\begin{array}{c}\text { (p-values not specified in this } \\
\text { study) } \\
\text { 1980s cohort: } \\
\text { U: HR 1.46 } \\
\text { M: HR 1.42 (0.98-2.07) } \\
\text { 1990s cohort: } \\
\text { U: (1) HR 1.99; (2) HR } 1.74 \\
\text { M: (1) HR 1.57 (0.95-2.62); } \\
\text { (2) HR 2.09 (1.02-4.28); } \\
\text { (3) HR 1.56 (1.95-2.56); } \\
\text { (4) HR 2.40 (1.18-4.91) }\end{array}$ \\
\hline Banez et al. [83] & $\mathrm{BCR}$ & $n=476$ & $\begin{array}{c}n=370 \text { no BCR } \\
n=106 \mathrm{BCR}\end{array}$ & ns & qMSP & PITX2 & $\begin{array}{l}\text { U: PITX2 (also in GS7 patients } \\
\text { only) } \\
\text { M: PITX2 [+ GS + pathological } \\
\text { T-stage + margin status] (also } \\
\text { in GS7 patients only) }\end{array}$ & $\begin{array}{c}\text { U: HR 2.99 }(1.99-4.48), p<0.001 ; \\
\text { GS7 only: HR 2.0 }(1.2-3.3) \\
p=0.005 ; \\
\text { M: HR 2.39 }(1.45-3.94), p<0.001, \\
\text { C-index = 0.77; GS7 only: HR 1.87 } \\
(1.1-3.1), p=0.02\end{array}$ \\
\hline
\end{tabular}


Table 1. Cont

\begin{tabular}{|c|c|c|c|c|c|c|c|c|}
\hline Study $[\text { Ref }]^{a}$ & Primary Outcomes Examined & $\begin{array}{l}\text { Total COHORT } \\
\text { SIZE }\end{array}$ & Additional COHORT DETAILS & $\begin{array}{c}\text { Follow-Up } \\
\text { (Years) }\end{array}$ & Method & Genes Examined & Genes Validated $^{b, c, d, e}$ & Results $\mathrm{g}$ \\
\hline Vasiljevis et al. [84] & Low vs. High GS & $n=48$ & $\begin{array}{c}n=9 \mathrm{GS} 6 \\
n=23 \mathrm{GS7} \\
n=7 \mathrm{GS} 8 \\
n=9 \mathrm{GS} 9-10\end{array}$ & NA & $\begin{array}{c}\text { Pyro } \\
\text { sequencing }\end{array}$ & $\begin{array}{c}\text { RARB, GSTP1, } \\
\text { HIN1, APC, BCL2, } \\
\text { CCND2, CDH13, } \\
\text { EGFR5, NKX2-5, } \\
\text { RASSF1, DPYS, } \\
\text { MDR 1, PTGS2, } \\
\text { EDNRB, MAL, } \\
\text { PDLIM4, HLAa, } \\
\text { TIG1, ESR1, SLIT2, } \\
\text { CDKN2A, MCAM, } \\
\text { SFN, THRB, CDH1, } \\
\text { TWIST1 }\end{array}$ & $\begin{array}{l}\text { U: SFN, SLIT2, SERPINB5 } \\
\text { (pairwise measures) } \\
\text { M: Not conducted }\end{array}$ & $\begin{array}{c}\text { U: SFN + SERPINB5: correctly } \\
\text { classified } 81 \% \text { of high GS; SFN + } \\
\text { SLIT2: } 62 \% \text {; SERPINB5 + SLIT2: } \\
62 \% \\
\text { M: NA }\end{array}$ \\
\hline Rosenbaum et al. [85] & $\begin{array}{l}\text { Primary: Progression } \\
\text { Secondary: Metastatic relapse } \\
\text { and/or PCa death }\end{array}$ & $n=95$ & $\begin{array}{c}n=47 \text { no progression, } \\
n=48 \text { progression } \\
(n=22 \text { BCR only, } \\
n=17 \text { metastatic relapse, } \\
n=9 \text { PCa death) } \\
\text { [all GS } 7(3+4)]\end{array}$ & $\begin{array}{l}\text { All: At least } 8 \\
\text { years } \\
\text { No progression } \\
\text { (Median } \\
\text { (range))-10 } \\
\text { (8-14) } \\
\text { Progression } \\
\text { (Median)-8 }\end{array}$ & qMSP & $\begin{array}{l}\text { RBM6, MT1G, } \\
\text { CDH1, AIM1, } \\
\text { KIF1A, PAK3 }\end{array}$ & $\begin{array}{c}\text { Progression: } \\
\text { U: AIM1 } \\
\text { M: AIM1 [+ age at diagnosis + } \\
\text { lymph node status] } \\
\text { Metastatic relapse and/or PCa } \\
\text { death: } \\
\text { U: None } \\
\text { M: None }\end{array}$ & $\begin{array}{c}\text { Progression: } \\
\text { U: HR } 0.4(0.18-0.89), p=0.02 \\
\text { M: HR }=0.45(0.2-1.0), p=0.05 \\
\text { Metastatic relapse and/or PCa } \\
\text { death: } \\
\text { U: non-sig } \\
\text { M: non-sig }\end{array}$ \\
\hline Vasiljevic et al. [86] & PCa death & $n=349$ & $\begin{array}{c}n=258 \text { no PCa death, } \\
n=91 \text { PCa death }\end{array}$ & $\begin{array}{l}\text { Median (max): } \\
9.5(20)\end{array}$ & $\begin{array}{c}\text { Pyro } \\
\text { sequencing }\end{array}$ & HSPB1 & $\begin{array}{c}\text { U: HSPB1 (in all samples and } \\
\text { in subgroup of GS }<7 \text { ) } \\
\text { M: } H S P B 1[+G S+\text { extent of } \\
\text { disease (proportion of TURP) + } \\
\text { PSA + HSPB } \times \text { GS interaction } \\
\text { term] }\end{array}$ & $\begin{array}{c}\text { U: HR } 1.77 \text { (per 50\% increase) } \\
(1.13-2.79), p=0.02 ; \mathrm{GS}<7: \\
p=0.028 \\
\text { M: HSPB1 }[\mathrm{HR} 1.18 \text { (per 10\% } \\
\text { increase) }(0.98-1.41), p=0.075] \\
\text { HSPB1 } \times \text { GS }[0.98(0.97-0.99), \\
p=0.014] ; \text { model with } H S P B 1 \text { vs. } \\
\text { clinical variables only: } \Delta \mathrm{x}^{2}=6.673 \\
\mathrm{df}=2, p=0.036\end{array}$ \\
\hline Dietrich et al. [87] & BCR & $\begin{array}{c}\text { Training cohort: } \\
n=157 \\
\text { Testing cohort: } \\
n=523\end{array}$ & $\begin{array}{c}\text { Training cohort: } n=\mathrm{ns} \text { BCR } \\
\text { Testing cohort: } \\
n=414 \text { no BCR, } \\
n=109 \text { BCR (same cohort as } \\
\text { Banez et al. [83]) }\end{array}$ & ns & qMSP & PITX2 & $\begin{array}{c}\text { Training cohort: } \\
\text { U: PITX2 } \\
\text { M: Not conducted } \\
\text { Testing cohort: } \\
\text { U: PITX2, (2) PITX2 (subgroup } \\
\text { of } \geq 75 \% \text { tumour content), (3) } \\
\text { PITX2 (subgroup of GS7 and } \geq \\
75 \% \text { tumour content) } \\
\text { M: (1) PITX2 [+ GS + } \\
\text { pathological T-stage + PSA + } \\
\text { surgical margins; ( () PITX2 [+ } \\
\text { tumour cell content + } \\
\text { pathological T-stage] }\end{array}$ & $\begin{array}{c}\text { Training cohort: } \\
\text { U: 3.479 (1.2599"C.614), } \\
p \text {-value not given } \\
\text { M: NA } \\
\text { Testing cohort: } \\
\text { U: HR 2.614 (1.79-53.807), } \\
p<0.001 ; \\
\text { (2) } \log \text {-rank } p<0.001 ; \\
\text { (3) log-rank } p=0.003 \\
\text { M: (1) HR 1.814 (1.232-2.673), } \\
p=0.003 ;(2) \text { HR } 1.889 \\
(1.259-2.832), p=0.002\end{array}$ \\
\hline
\end{tabular}


Table 1. Cont

\begin{tabular}{|c|c|c|c|c|c|c|c|c|}
\hline Study [Ref $]^{a}$ & Primary Outcomes Examined & $\begin{array}{l}\text { Total COHORT } \\
\text { SIZE }\end{array}$ & Additional COHORT DETAILS & $\begin{array}{l}\text { Follow-Up } \\
\text { (Years) }\end{array}$ & Method & Genes Examined & Genes Validated ${ }^{b, c, d, e}$ & Results $\mathrm{g}$ \\
\hline Richiardi et al. [88] & PCa death & $n=157$ & $\begin{array}{c}n=114 \text { no PCa death, } n=43 \mathrm{PCa} \\
\text { death } \\
\text { [Non-neoplastic tissue adjacent } \\
\text { to prostate tumour] } \\
\text { [nested in the } 2 \text { cohorts of } \\
\text { Richiardi et al. [82]] }\end{array}$ & $\begin{array}{l}\text { Median (range): } \\
6.8(0.03-24.1)\end{array}$ & qMSP & APC, GSTP1 & $\begin{array}{c}\text { U: (1) APC, (2) GSTP1 } \\
\text { M: : APC + GSTP1 [ + age at } \\
\text { diagnosis + year of diagnosis + } \\
\text { source of tumour tissue + } \\
\text { methylation in prostate tumour } \\
\text { tissue + GS] (also in restricted } \\
\text { analyses of first } 5 \text { years of } \\
\text { follow-up) }\end{array}$ & 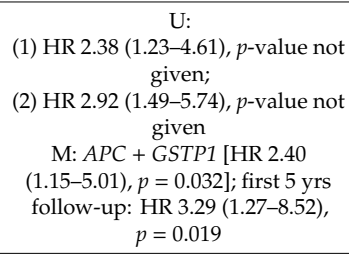 \\
\hline Moritz et al. [89] & BCR & $n=84$ & $\begin{array}{c}n=31 \text { no BCR, } n=53 \mathrm{BCR} \\
{[\mathrm{GS} 5-7]}\end{array}$ & $\begin{array}{c}\text { Mean; median } \\
\text { (range): } 4 ; 1.8 \\
\quad(0-10.9)\end{array}$ & qMSP & $\begin{array}{c}\text { APC, GSTP1, } \\
\text { PTGS2, RARB, TIG1 }\end{array}$ & $\begin{array}{l}\mathrm{U}: R A R B \\
\text { M: None }\end{array}$ & $\begin{array}{c}\mathrm{U}: \mathrm{HR} 2.686(1.147-6.291), p=0.023 \\
\text { M: non-sig }\end{array}$ \\
\hline Vasiljevic et al. [90] & PCa death & $n=367$ & $\begin{array}{c}n=268 \text { no PCa death, } n=99 \mathrm{PCa} \\
\text { death } \\
\text { [TURP tissues of men who chose } \\
\text { not to be treated for at least } 6 \\
\text { months following } \\
\text { diagnosis-TAPG cohort] }\end{array}$ & $\begin{array}{l}\text { Median (range): } \\
9.5(0.7-19.6)\end{array}$ & $\begin{array}{l}\text { Pyro } \\
\text { sequencing }\end{array}$ & $\begin{array}{l}\text { GSTP1, APC, RARB, } \\
\text { CCND2, SLIT2, SFN, } \\
\text { SERPINB5, MAL, } \\
\text { DPYS, TIG1, HIN1, } \\
\text { PDLIM4 and HSPB1 }\end{array}$ & $\begin{array}{c}\text { U: (1) GSTP1; (2) APC; (3) } \\
\text { RARB; (4) CCND2; (5) SLIT2; } \\
\text { (6) SFN; (7) MAL; (8) DPYS; (9) } \\
\text { TIG1; (10) HIN1; (11) PDLIM4; } \\
\text { and (12) HSPB1 } \\
\text { M: DPYS + HSPB1 + CCND2 [+ } \\
\text { GS, PSA + HSPB1 × GS } \\
\text { interaction term] }\end{array}$ & $\begin{array}{c}\text { U: All genes had an HR (per } 10 \% \\
\text { increment between } 1.09 \text { and } 1.28, \\
\text { and } p \text { between } 2.9 \times 10^{-6} \text { and } 0.029 . \\
\text { M: DPYS [HR } 1.13(1.03-1.25), \\
p=0.012], H S P B 1 \text { [HR } 2.39 \\
(1.15-4.97), p=0.019], C C N D 22 \text { HR } \\
0.86(0.75-0.98), p=0.024], H S P B \\
\times \text { GS [HR } 0.89(0.81-0.97) \\
p=0.012], \text { C-index }=0.83 \text { (vs. } 0.74 \\
\text { for GS + PSA only) }\end{array}$ \\
\hline Vasiljevic et al. [91] & PCa death & $n=135$ & $\begin{array}{c}n=90 \text { no PCa death, } n=45 \text { PCa } \\
\text { death } \\
\text { [all GS } \leq 7] \\
\text { [subset of cohort from Vasiljevic } \\
\text { et al. [90]] }\end{array}$ & $\begin{array}{l}\text { No PCa death } \\
\text { (Mean)-7.8 } \\
\text { PCa death } \\
\text { (Median } \\
\text { (max)-15.3 } \\
\text { (20) }\end{array}$ & $\begin{array}{c}\text { Pyro } \\
\text { sequencing }\end{array}$ & $\begin{array}{c}\text { PITX2, WNT5A, } \\
\text { SPARC, EPB4L 1L } 3 \\
\text { and TPM4 }\end{array}$ & $\begin{array}{c}\text { U: PITX2 (FDR adjustment = } \\
5 \%) \\
\text { M: not conducted }\end{array}$ & $\begin{array}{c}\text { U: OR } 1.56 \text { (per } 10 \% \text { increment) } \\
(1.17-2.08) \text {, adjusted } p=0.005 \\
\text { M: NA }\end{array}$ \\
\hline Maldonado et al. [92] & Progression & $n=452$ & $\begin{array}{c}n=193 \text { no progression } \\
n=259 \text { progression }\end{array}$ & Range: 3-11 & qMSP & $\begin{array}{c}\text { AIM1, APC, CCND2, } \\
\text { GPX3, GSTP1, } \\
\text { MCAM, RARB } \\
\text { SSBP2, TIMP3 }\end{array}$ & $\begin{array}{c}\text { U: GSTP1 } \\
\text { M: GSTP1 [+ age at surgery + } \\
\text { pre-op PSA + positive surgical } \\
\text { margins + surgery year + } \\
\text { pathological T-stage + GS] } \\
\text { (organ confined disease only) }\end{array}$ & $\begin{array}{l}\text { U: Wilcoxon rank sum test } p=0.01 \\
\text { M: OR } 1.73(1.00-3.02), p=0.05\end{array}$ \\
\hline Daniunaite et al. [93] & BCR & $n=149$ & $n=\mathrm{ns} \mathrm{BCR}$ & $\begin{array}{c}\text { No BCR } \\
\text { (Median } \\
\text { (range))-3.4 } \\
(0.2-5.5)\end{array}$ & qMSP & $\begin{array}{c}\text { RARB, GSTP1, } \\
\text { RASSF1, MGMT, } \\
\text { DAPK1, p16 and } p 14\end{array}$ & $\begin{array}{l}\text { U: (1) RASSF1; (2) DAPK; (3) } \\
\text { RASSF1 +/or DAPK1 } \\
\text { M: RASSF1 [+pT] (GS6 only) }\end{array}$ & $\begin{array}{l}\text { U: (1) HR 2.27 (1.12-4.63), } p=0.019 \text {; } \\
\text { (2) HR 2.55 (1.11-5.84), } p=0.045 \text {; } \\
\text { (3) HR 2.20 (1.06-4.54), } p=0.027 \\
\text { M: HR 5.81 (1.08-31.22), } p=0.042\end{array}$ \\
\hline
\end{tabular}


Table 1. Cont

\begin{tabular}{|c|c|c|c|c|c|c|c|c|}
\hline Study $[\operatorname{Ref}]^{a}$ & Primary Outcomes Examined & $\begin{array}{l}\text { Total COHORT } \\
\text { SIZE }\end{array}$ & Additional COHORT DETAILS & $\begin{array}{l}\text { Follow-Up } \\
\text { (Years) }\end{array}$ & Method & Genes Examined & Genes Validated ${ }^{b}, c, d, e$ & Results $\mathrm{g}$ \\
\hline Litovkin et al. [94] & Clinical Failure & $\begin{array}{l}\text { Training cohort: } \\
n=147 \\
\text { Validation } \\
\text { cohort: } \\
n=71\end{array}$ & $\begin{array}{c}\text { Training cohort: } \\
n=117 \text { no CF } \\
n=30 \mathrm{CF} \\
\text { Validation cohort: } \\
n=58 \text { no CF } \\
n=13 \mathrm{CF} \\
\text { [High-risk PCa patients: Clinical } \\
\text { stage } \geq \text { T3a, GS } 8-10 \text { and/or PSA } \\
\quad>20 \mathrm{ng} / \mathrm{mL}]\end{array}$ & $\begin{array}{l}\text { Median (range): } \\
\text { Training } \\
\text { cohort-6.8 } \\
\text { (0.1-12.8) } \\
\text { Validation } \\
\text { cohort-11.5 } \\
(1.4-18.8)\end{array}$ & $\begin{array}{l}\text { Multiplex } \\
\text { qMSP }\end{array}$ & $\begin{array}{c}A P C, C C N D 2 \\
G S T P 1, P T G S 2 \text { and } \\
R A R B\end{array}$ & $\begin{array}{c}\text { Training cohort: } \\
\text { U: (1) GSTP1 (trichotomized); } \\
\text { PTGS2 } \\
\text { M: [+ pathological T-stage + } \\
\text { GS + pre-op PSA] (1) GSTP1 } \\
\text { (trichotomized); (2) PTGS2 } \\
\text { Validation cohort: } \\
\text { U: (1) GSTP1 (trichotomized); } \\
\text { (2) CCND2; (3) RARB } \\
\text { M: [+ pathological T-stage + } \\
\text { GS + pre-op PSA] (1) GSTP1 } \\
\text { (trichotomized); (2); (3) RARB }\end{array}$ & $\begin{array}{c}\text { Training cohort: } \\
\text { U: (1) HR 2.96 (1.38-6.36), } p=0.005 \text {; } \\
\text { (2) HR 0.39 (0.18-0.81), } p=0.013 \\
\text { M: (1) HR 3.65 (1.65-8.07), } \\
p=0.001, \text { C-index }=0.72 \text { (vs. 0.68 } \\
\text { for stage + GS + PSA only); (2) HR } \\
\text { 0.21 (0.09-0.50), } p<0.001 \\
\text { Validation cohort: } \\
\text { U: (1) HR 3.34 (1.38-4.87), } p=0.003 \text {; } \\
\text { (2) HR 0.21 (0.07-0.65), } p=0.007 ; \\
\text { (3) HR 3.45 (1.09-10.87), } p=0.035 \\
\text { M: (1)HR 4.27 (1.03-17.72), } \\
p=0.046, \text { C-index }=0.80 \text { (vs. } 0.75 \\
\text { for stage + GS + PSA only); (2) HR } \\
0.19 \text { (0.05-0.79), } p=0.022 ;(3) \text { HR } \\
\text { 3.81 (1.09-13.34), } p=0.036\end{array}$ \\
\hline Carozzi et al. [95] & $\begin{array}{l}\text { PCa death } \\
\text { (within } 10 \text { yrs of diagnosis) }\end{array}$ & $n=129$ & $\begin{array}{c}n=91 \text { alive }>10 \mathrm{yrs}, n=38 \mathrm{died} \\
\leq 10 \text { years } \\
\text { [Needle biopsy specimens] }\end{array}$ & ns & $\begin{array}{c}\text { Pyro } \\
\text { sequencing }\end{array}$ & $\begin{array}{c}\text { APC, SFN, } \\
\text { SERPINB5, SLIT2, } \\
\text { PITX2, AR }\end{array}$ & $\begin{array}{l}\text { U: SERPINB5 } \\
\text { M: None }\end{array}$ & $\begin{array}{c}\text { U: 2nd quartile [OR 1.54 } \\
(0.56-4.23)] \text {, 3rd quartile [HR } 2.42 \\
(0.91-6.49) ; p=0.0474 \\
\text { M: non-sig }\end{array}$ \\
\hline Rybicki et al. [96] & $\mathrm{BCR}$ & $n=353$ & $\begin{array}{c}n=262 \text { no BCR, } \\
n=91 \text { BCR (White: } n=152 \text { no } \\
\text { BCR, } n=54 \text { BCR } \\
\text { African American: } \\
n=110 \text { no BCR, } \\
n=37 \text { BCR) } \\
\text { [Benign prostate } \\
\text { specimens - patients who } \\
\text { eventually developed PCa] }\end{array}$ & $\begin{array}{l}\text { Median (range): } \\
\text { No BCR-6.3 } \\
\quad(1-19) \\
\text { BCR-1.9 (0.2-14) }\end{array}$ & $\begin{array}{l}\text { Nested } \\
\text { MSP }\end{array}$ & $\begin{array}{l}\text { RARB, APC, } \\
\text { CTNND2, RASSF1 } \\
\text { and MGMT }\end{array}$ & $\begin{array}{l}\text { U: APC (White patients) } \\
\text { M: (1) APC (White patients) [+ } \\
\text { age at diagnosis + tumour } \\
\text { stage + GS + pre-op PSA, } \\
\text { treatment type]; (2) APC } \\
\text { (White patients) [+ no other } \\
\text { gene methylated + low PSA at } \\
\text { cohort entry + inflammation } \\
\text { was present]; (3) RARB } \\
\text { (African American patients) [+ } \\
\text { another gene methylated + } \\
\text { absence of inflammation] }\end{array}$ & $\begin{array}{c}\text { U: HR } 2.07(1.15-3.74), p=0.02 \\
\text { M: } \\
\text { (1) HR 2.26 (1.23-4.16), } p=0.01 \text {; } \\
\text { (2) HR 3.28 (1.33-8.11), } p=0.01 ; \\
\text { (3) HR = 3.80 (1.07-13.53), } p=0.04\end{array}$ \\
\hline Holmes et al. [97] & $\mathrm{BCR}$ & $\begin{array}{l}\text { Cohort } 1 \\
\text { (TCGA): } n=498 \\
\text { Cohort 2: } n= \\
300\end{array}$ & $\begin{array}{c}\text { Cohort 1: } \\
n=\text { ns BCR } \\
\text { Cohort 2: } \\
n=\text { ns BCR }\end{array}$ & $\begin{array}{l}\text { Mean; median: } \\
\text { Cohort 1-1.83; } \\
1.3 \\
\text { Cohort 2-5.5; } \\
5.2\end{array}$ & $\begin{array}{l}\text { Cohort } \\
1-\text { HM450K } \\
\text { Microarray } \\
\text { Cohort } \\
2-\text { qMSP }\end{array}$ & PITX3, РITX2 & $\begin{array}{c}\text { Cohort 1: } \\
\text { U: (1) PITX3; (2) PITX3 + } \\
\text { PITX2 } \\
\text { M: Not conducted } \\
\text { Cohort 2: } \\
\text { U: (1) PITX3; (2) PITX2; (3) } \\
\text { PITX3 + PITX2 } \\
\text { M: Not conducted }\end{array}$ & $\begin{array}{c}\text { Cohort } 1 \\
\text { U: (1) HR 1.83 (1.07-3.11), } p=0.027 ; \\
\text { (2) HR 2.20 (1.25-3.87), } p=0.006 ; \\
\text { (3) LR = 12.77, log-rank } p=0.002 \\
\text { M: NA } \\
\text { Cohort 2: } \\
\text { U: (1) HR 2.56 (1.44-4.54), } \\
p=0.001 \text {; (2) see Reference 99; } \\
\text { (3) LR = 12.14, log-rank } p=0.002 \\
\text { M: NA }\end{array}$ \\
\hline
\end{tabular}


Table 1. Cont

\begin{tabular}{|c|c|c|c|c|c|c|c|c|}
\hline Study $[\text { Ref }]^{\text {a }}$ & Primary Outcomes Examined & $\begin{array}{c}\text { Total COHORT } \\
\text { SIZE }\end{array}$ & Additional COHORT DETAILS & $\begin{array}{l}\text { Follow-Up } \\
\text { (Years) }\end{array}$ & Method & Genes Examined & Genes Validated ${ }^{b, c, d, e}$ & Results $\mathrm{g}$ \\
\hline Ahmad et al. [98] & PCa death & $n=385$ & $\begin{array}{c}n=328 \text { no PCa death, } \\
n=57 \text { PCa death } \\
\text { [low (0-2) to intermediate (3-5) } \\
\text { risk CAPRA scores] } \\
\text { [from TAPG cohort in Vasiljevic } \\
\text { et al. [90]] }\end{array}$ & $\begin{array}{c}\text { Median (IQR): } \\
11.36 \\
(6.20-14.72)\end{array}$ & $\begin{array}{c}\text { Pyro } \\
\text { sequencing }\end{array}$ & $\begin{array}{c}\text { HSPB1, CCND2, } \\
\text { TIG1, DPYS, PITX2, } \\
\text { MAL }\end{array}$ & $\begin{array}{c}\text { Methylation score: HSPB1 + } \\
\text { CCND2 + TIG1 + NPYS + } \\
\text { PITX2 + MAL + CCND2. } \\
\text { HSPB1 interaction term. } \\
\text { U: Methylation score } \\
\text { M: Methylation score [+ } \\
\text { CAPRA] }\end{array}$ & $\begin{array}{l}\text { U: HR } 2.72(1.933 .8), p<10^{-8} \\
\text { M: HR 2.02 (1.402.92), } p<10^{-3} \text {, } \\
\text { C-index of full model }=0.74 \\
\text { Sensitivity }=83 \% \text {, Specificity }=44 \% \\
\text { (vs. CAPRA only: } 68 \% / 44 \% \text { ) } \\
\text { At } 10 \text { yr follow-up: AUC }=0.74 \text { (vs. } \\
\text { CAPRA only: } 0.62 \text { ) }\end{array}$ \\
\hline Uhl et al. [99] & $\begin{array}{c}\text { Cohort 1: BCR } \\
\text { Cohort 2: ISUP grade group } \\
\text { (as surrogate for survival) }\end{array}$ & $n=206$ & $\begin{array}{c}\text { Cohort 1: } n=208 \text { no BCR, } \\
n=52 \text { BCR } \\
\text { [same cohort as Cohort } 2 \text { in } \\
\text { Holmes et al. [97]] } \\
\text { Cohort 2: } \\
n=32 \\
\text { [core needle biopsy specimens] }\end{array}$ & $\begin{array}{c}\text { Cohort 1 (Mean; } \\
\text { median } \\
\text { (range))- } 5.5 ; \\
5.2(0-12.1) \\
\text { Cohort 2-NA }\end{array}$ & qMSP & PITX2 & $\begin{array}{c}\text { Cohort 1: } \\
\text { U: PITX2 } \\
\text { M: None } \\
\text { Cohort 2: } \\
\text { U: PITX2 (median, mean and } \\
\text { maximum levels) } \\
\text { M: Not conducted }\end{array}$ & $\begin{array}{c}\text { Cohort 1: } \\
\text { U: HR 1.77 (1.01-3.10), } p=0.046 \\
\text { M: non-sig } \\
\text { Cohort 2: } \\
\text { U: median }[r=0.456, p=0.010] \\
\text { mean }[r=0.478, p=0.007] \\
\text { maximum }[r=0.495 ; p=0.005] \\
\text { M: NA }\end{array}$ \\
\hline
\end{tabular}

Abbreviations: $\mathrm{AUC}=$ area under the curve; $\mathrm{CF}=$ clinical failure; $\mathrm{df}=$ degrees of freedom; $\mathrm{GS}=$ Gleason Score; $\mathrm{HR}=$ hazard ratio; IQR $=$ interquartile range; $\mathrm{LR}=$ likelihood ratio; $\mathrm{M}=$ multivariate analysis; $\mathrm{MSP}=$ methylation-specific PCR; NA = not applicable; non-sig = nonsignificant; $\mathrm{ns}$ = not specified; $\mathrm{OR}=$ odds ratio; $\mathrm{PCa}=$ prostate cancer; $\mathrm{PSA}=$ prostate-specific antigen; qMSP = quantitative methylation-specific PCR; $\mathrm{r}=$ correlation coefficient; $\mathrm{U}=$ univariate analysis. Definitions: BCR: Biochemical recurrence-PSA elevations $\geq 0.2 \mathrm{ng} / \mathrm{mL}$ post-RP, except [77] $>0.4 \mathrm{ng} / \mathrm{mL}$ and [89] $>0.1 \mathrm{ng} / \mathrm{mL}$; clinical failure: either of local recurrence or metastatic relapse; clinical T-stage: tumour staging based on results of digital rectal examination, PSA levels and GS. Local recurrence: cancer observed on prostatic bed, confirmed by histological analysis of biopsies; metastatic relapse: metastatic deposits (visceral, bony metastasis) confirmed by positive biopsies or CT/bone scans; pathological T-stage: tumour staging based on pathological examination of surgically removed prostate tissue; PCa death: prostate cancer-specific death; progression: either of BCR, metastatic relapse or PCa death; recurrence: either of BCR, local recurrence or metastatic relapse. ${ }^{a}$ All studies are on prostate cancer tissues from radical prostatectomy, unless specified. ${ }^{b}$ Univariate $(\mathrm{U})$ or Multivariate $(\mathrm{M})$ analyses. ${ }^{\mathrm{c}}$ Plus $(+)$ sign indicates variables in the same multivariate model or methylation score together. ${ }^{d}$ Square bracket ([[]) indicate the clinicopathological factors adjusted for in each multivariate model. ${ }^{\text {e }}$ The use of bracketed numbers; e.g., (1), (2), indicates different genes, sets of genes or multivariate models validated in the respective study. ${ }^{\mathrm{f}}$ Genes validated may have been impacted by high number of missing cases. ${ }^{\mathrm{g}}$ Number in brackets following HR or OR indicate the $95 \%$ confidence interval. 


\subsubsection{GSTP1}

The glutathione S-transferase pi gene (GSTP1) is the most well-studied DNA methylation biomarker of PCa, particularly in diagnosis [100]. It encodes glutathione S-transferase, a detoxifying enzyme and tumour suppressor involved in drug metabolism and protecting DNA from oxidative damage [101]. Hypermethylation (increased methylation) of GSTP1 is observed frequently in PCa tissue but rarely in histologically negative prostate tissues [102]. We identified 15 candidate prognostic biomarker studies that have studied GSTP1 methylation, with its prognostic value validated in 8 of these studies (Table 1). The earliest of these studies assessed GSTP1 methylation using qMSP in a cohort of GS $7(3+4)$ patients $(n=74)$, and reported that GSTP1 hypermethylation was significantly associated with time to progression (any of BCR, metastatic relapse and/or PCa death) in univariate analysis, and as an independent predictor in multivariate analysis with other candidate genes [75]. Subsequent studies of RP tissue, using qMSP, have again found GSTP1 to be an independent prognostic factor. Briefly, Maldonado et al. used a large cohort $(n=452)$ to show that GSTP1 methylation was a significant independent prognostic factor of progression in a multivariate model adjusting for age at surgery, pre-op PSA, surgery year, surgical margins, pathological T-stage and GS; but only in samples from early, organ-confined disease $(n=183)$ [92]. Litovkin et. al. found trichotomised GSTP1 methylation to be an independent prognostic predictor (when adjusted for GS, pathological T-stage and pre-op PSA levels) of clinical failure (see Table 1 for definition) in two cohorts (Training: $n=147$, Validation: $n=71$ ) of high-risk PCa patients [94]. In a study of non-neoplastic tissue adjacent to the prostate tumour from PCa patients with follow-up up to 24 years $(n=157)$, the presence of GSTP1 methylation increased risk of PCa death by almost 3-fold, and remained an independent prognostic factor in multivariate models in combination with APC methylation, GS, age at diagnosis, year of diagnosis, source of tumour tissue and methylation in matched tumour tissue [88]. Another study assessing PCa death, using pyrosequencing of TURP tissue $(n=367)$, also found univariate associations with GSTP1 methylation [90].

Two small studies with BCR as the clinical endpoint observed associations with GSTP1 methylation: (1) in a univariate analysis, using sextant biopsy cores $(n=83)$ [77] and (2) as part of a multigene signature, using RP tissue $(n=41)$ [78]. Another small study $(n=64)$ investigating the broader outcome of recurrence (any of BCR, local recurrence or metastatic relapse) observed associations with GSTP1 methylation at $3 \mathrm{CpG}$ units in univariate analysis only [81]. Importantly, of the 15 studies assessing GSTP1 methylation as a prognostic biomarker, 7 studies did not find any prognostic value in GSTP1 methylation in the prediction of BCR $[74,76,79,89,93]$, low vs. high GS cancers [84] or PCa death [77,82].

\subsubsection{APC}

$A P C$ is a tumour suppressor gene which encodes the adenomatous polyposis coli (APC) protein, with a known role in the cellular processes of tumourigenesis [103]. Hypermethylation of APC is observed in PCa tumours [104] and a number of studies have demonstrated its prognostic potential (Table 1). In two of these studies, APC hypermethylation was included in multivariate models alongside GSTP1 methylation to predict progression in GS 7 patients [75] and PCa death (using DNA from non-neoplastic adjacent tissue) [88]. APC methylation has also been observed to be an individual methylation marker of BCR $[77,96]$ and PCa death $[77,82]$. In the study by Henrique et al., methylation levels of 5 genes (APC, CCND2, GSTP1, RARB, RASSF1) were quantified by qMSP of DNA extracted from sextant biopsies $(n=83)$, of which $A P C$ was the only gene significantly associated with both BCR and PCa death in univariate and multivariate analyses with other clinicopathological factors. [77]. A separate study that used MSP to quantify APC, RUNX3, GSTP1 reported that APC was the only independent prognostic gene in the prediction of PCa death across two cohorts of RP patients, one before PSA-testing was widespread (1980s cohort: $n=216)$ and one after the introduction of PSA-testing (1990s cohort: $n=243$ ); adjusting for source of tumour tissue, GS and follow-up duration [82]. One study looking at BCR examined APC methylation using nested MSP in benign prostate specimens (needle biopsy or TURP) from patients who eventually developed PCa $(n=353)$ 
and found associations between APC and risk of BCR in White patients only ( $n=206)$, adjusting for age, tumour stage, GS, PSA level and treatment type [96]. Two other studies of APC methylation levels reported only univariate associations with risk of BCR [78] and PCa death in TURP tissues [90]. It should be noted that, while these studies provide evidence for the potential prognostic value of $A P C$ methylation, a number of other studies did not observe such associations with predicting risk of BCR [74,79,89], low vs. high GS [84], clinical failure [94], progression [92] and PCa death within 10 years of diagnosis [95].

\subsubsection{RARB}

The $R A R B$ gene encodes the retinoic acid receptor beta protein, a nuclear transcriptional regulator important in cellular signalling in cell growth and differentiation processes, and often silenced and hypermethylated in PCa [105]. In total, 5 of the 12 studies examining RARB methylation have reported its potential prognostic utility, of which 2 studies have observed $R A R B$ methylation levels to be an independent prognostic variable in multivariate models including other clinicopathological factors $[94,96]$. Briefly, the qMSP study by Litovkin et al., examining prediction of clinical failure in high-risk patients, found dichotomised $R A R B$ methylation, significant in univariate and multivariate analyses (adjusted for GS, pathological T-stage and PSA) in a small validation cohort $(n=41)$, but not in the training cohort $(n=71)$ [94]. In their more recent study, methylation of the RARB promoter region significantly increased risk of BCR in African American patients $(n=147)$, but only when another gene was methylated (APC, CTNND2, RASSF1 or MGMT) and no inflammation was present in the prostate specimen [96]. Other studies reported only univariate associations between methylation and prognosis with the clinical endpoints of PCa death [90] and BCR if hypermethylated alongside four or more candidate genes [78] or in RP patients with GS $\leq 7$ [89]. Other studies assessing BCR [76,93], recurrence or progression $[75,81,92]$ and PCa death [77] found no associations with RARB methylation.

\subsubsection{PITX2}

PITX2 encodes the paired-like homeodomain transcription factor 2, induced by the WNT pathway to activate growth regulating genes required for cell-type specific proliferation [106]. Aberrant PITX2 methylation has been observed in multiple tumour types including breast [107] and PCa [80]. Of nine studies on PITX2 methylation in Table 1, all but one study, which assessed methylation in benign prostate specimens [96], reported significant associations with risk of progression. The first study by Weiss and colleagues, observed PITX2 methylation, quantified by qMSP, as the strongest and only independent predictor of $\mathrm{BCR}$, providing additional prognostic information to existing clinicopathological factors of GS and pathological T-stage [80]. A subsequent study of $n=476$ patients confirmed the association between PITX2 hypermethylation, also quantified by qMSP, and increased BCR risk in a multivariate model with GS, pathological T-stage, surgical margin, age and PSA levels [83]. Another study, using samples from the same cohort as [83], plus a smaller training cohort (training cohort: $n=157$, testing cohort: $n=523$ ) observed that PITX2 methylation added prognostic information to GS, pathological T-stage and surgical margins in the prediction of BCR in multivariate cox analysis. Vanaja et al. constructed a methylation score consisting of $11 \mathrm{CpG}$ units across 5 genes (from the EpiTYPER MassARRAY platform, see Table 1) including sites in the PITX2 promoter region to predict recurrence within 5 years, in a model combined with GS, pre-op PSA, seminal vesicle involvement and margin status, achieving an AUC of 0.852 (Sensitivity/Specificity $=80 / 81.2 \%$ ) [81]. In a more recent study investigating PCa death as the clinical endpoint in a large cohort of patient-derived TURP tissue $(n=385)$, a prognostic model was built on 6 methylation biomarkers (see Table 1) including PITX2, and was able to improve on the sensitivity of the Cancer of the Prostate Risk Assessment (CAPRA) score to predict aggressive PCa at 10 years follow-up with an AUC of 0.74 (Table 1) [98]. A smaller study of risk of PCa death in patients with GS $\leq 7$ ( $n=135$, median follow-up of 15 years, TURP tissue specimens), also using pyrosequencing, reported a significant association with increased PITX2 methylation levels [91]. Two additional studies from the same lab likewise 
reported univariate associations between PITX2 methylation and BCR, with no multivariate analysis with clinicopathological factors conducted $[97,99]$. Additional analyses showed that combinations of both PITX2 and PITX3 methylation were associated with BCR [97] and that there was a strong correlation between PITX2 methylation and ISUP grade group in core needle biopsy specimens [99].

\subsubsection{CCND2 and PTGS2}

CCND2 and PTGS2 have been studied in eight and six studies respectively, with four studies reporting modest evidence of potential prognostic value for each gene. Hypermethylation of CCND2 has been reported as an independent prognostic marker of clinical failure [94], and for prediction of progression [75] and PCa death $[90,98]$ in combination with other markers. Three small studies (each $n$ $\leq 60)$ observed associations between higher PTGS2 methylation and increased risk of BCR $[74,76,78]$ with one study reporting a nine-fold increased risk when combined with CD44 methylation [76], whilst a larger two-cohort study reported associations with clinical failure in the training cohort only [94].

\subsubsection{Other Candidate Genes}

Other candidate genes that have been investigated in at least three studies include RASSF1, TIG1, EDNRB, MGMT, MDR1, CDKN2A, TIMP3, CDH1, PDLIM4, DPYS, MAL, SLIT2, SFN and HSPB1 (Table 1). Methylation of four of these genes (MGMT, CDKN2A, TIMP3, CDH1) was not found to have any prognostic utility, whilst EDNRB, MDR1 and PDLIM4 methylation was only reported to have significant univariate associations with disease risk in one study each (Figure 3). Surprisingly, RASSF1, frequently hypermethylated in PCa and part of the ConfirmMDX panel [56], has only been reported to have associations with risk of BCR in two small studies [77,93]. TIG1 was not observed to be an independent prognostic factor alone, only in combination with other genes for prediction of PCa death in low-to-intermediate-risk patients [98]. Pairwise combinations of high SLIT2, SFN and SERPINB5 methylation were able to classify high from low GS patients in random forest modelling of a small cohort $(n=48)$ [84]. DPYS, MAL and HSPB1 emerge as potential prognostic biomarkers, with HSPB1 in particular validating as an independent prognostic factor of PCa death in the three studies it has been investigated in $[86,90,98]$. SERPINB5 and AIM1, the only markers found to have significant associations with progression [95] and overall survival [85] have only been investigated in two small independent studies each thus far, and require further validation in larger cohorts. And finally, new candidate genes from different biological pathways have been explored recently (e.g., PD1-, PD-L1, CDO1, TFF3, ZNF660) [108-112] and also require further validation.

In summary, the evidence for the prognostic value of the most extensively studied candidate genes (e.g., GSTP1, APC, RARB, CCND2, PTGS2) is conflicting, potentially due to differences in study designs including diversity in sample type, cohort size, clinical endpoints examined, methylation profiling methodologies, analytical approach and clinicopathological factors adjusted for in multivariate analyses. Thus far, PITX2 methylation has shown the most robust evidence of providing additive prognostic information to traditional clinicopathological markers, in particular in the prediction of BCR progression.

\subsection{Genome-Wide Prognostic Biomarker Discovery Studies}

Technological advancements in microarray and next-generation sequencing technologies over the last decade have enabled hypothesis-free, genome-wide screening for new prognostic methylation biomarkers. Platforms that have been used for epigenome-wide screens include restriction enzyme-based, capture-based and microarray-based platforms, together with next-generation sequencing, summarised in Figure 2. In this section, we summarise genome-wide prognostic methylation biomarker discovery studies in primary PCa tumours, with all but one study performed on RP tissue (Table 2). Table 2 highlights the novel biomarkers that were further validated within the original or subsequent studies, and details the top 20 genes for studies that found a large number of significantly associated markers. We refer readers to the original studies for the full lists of methylation 
markers. We focus on those studies that used measures of disease risk to identify potential biomarkers (for example, comparing methylation of patients of different GS, or different survival outcomes), rather than studies that compared methylation differences between benign and tumour tissue to identify disease-specific biomarkers, with assessment of their prognostic value as only a secondary step [113-119]. 
Table 2. Candidate (a priori) prognostic methylated tissue-based biomarker studies.

\begin{tabular}{|c|c|c|c|c|c|c|c|c|c|}
\hline Study $[\text { Ref }]^{a}$ & Approach (Discovery) & $\begin{array}{l}\text { Cohort Size } \\
\text { (Discovery) }\end{array}$ & $\begin{array}{l}\text { Follow-Up } \\
\text { (Discovery) } \\
\text { [Years] }\end{array}$ & $\begin{array}{l}\text { Approach } \\
\text { (Validation) }\end{array}$ & $\begin{array}{l}\text { Cohort Size } \\
\text { (Validation) }\end{array}$ & $\begin{array}{l}\text { Method } \\
\text { (Validation) }\end{array}$ & $\begin{array}{l}\text { Follow-Up } \\
\text { (Validation) } \\
\text { [Years] }\end{array}$ & Final Markers Identified (Validation) & Key Results (Validation) $\mathrm{g}$ \\
\hline \multicolumn{10}{|c|}{ Restriction-based methylation sequencing platforms ${ }^{\mathrm{h}}$} \\
\hline \multicolumn{10}{|c|}{ 1. Methylation sensitive arbitrarily primed PCR and methylated $\mathrm{CPG}$ island amplification } \\
\hline $\begin{array}{l}\text { Cottrell et al. } \\
{[120]}\end{array}$ & $\begin{array}{l}\text { Low GS ( } 2-6 \text { with no } \\
\text { grade } 4 \text { or } 5 \text { patterns) vs. } \\
\text { High GS }(8-10) \\
\text { Early BCR }(<2 \text { yrs } \\
\text { post-RP) vs. no early } \\
\text { BCR ( }>4 \text { yrs })\end{array}$ & $\begin{array}{c}n=5 \text { Low GS, } \\
n=5 \text { High GS, } \\
n=5 \text { no early } \\
\text { BCR, } \\
n=5 \text { early } \\
\text { BCR }\end{array}$ & Range: $2-4$ & $\begin{array}{l}\text { Low GS vs. } \\
\text { High GS } \\
\text { Early BCR vs. } \\
\text { no early BCR }\end{array}$ & $\begin{array}{c}\text { Cohort } 1: \\
n=304(130 \text { low GS, } \\
96 \text { high GS; } 88 \text { no } \\
\text { BCR, } 63 \text { BCR }) \\
\text { Cohort 2: } \\
n=233 \text { (28 low GS, } 27 \\
\text { high GS; } 134 \text { no BCR, } \\
59 \text { BCR) }\end{array}$ & $\begin{array}{l}\text { 1. Custom } \\
\text { methylation } \\
\text { oligonucleotide } \\
\text { microarray } \\
\text { 2. MethyLight } \\
\text { (qMSP) }\end{array}$ & Range: $2-4$ & $\begin{array}{c}\text { Low GS vs. High GS: Cohort 1-U: (1) } \\
\text { ABDHG, (2) Chr3-EST, (3) GPR7, (4) } \\
\text { NOTCH, (5) KBTBD6; M: not conducted } \\
\text { Cohort 2-U: (1) ABDH9, (2) Chr3-EST; } \\
\text { M: not conducted } \\
\text { Early BCR vs. no early BCR: } \\
\text { Cohort 1-U: (1) ABDH9, (2) ABDH9 } \\
\text { (intermediate GS 6, 7 patients only) (3) } \\
\text { Chr3-EST, (4) Chr3-EST (intermediate } \\
\text { GS), (5) GPR7, (6) GPR7 (intermediate } \\
\text { GS); M: not conducted } \\
\text { Cohort 2-U: (1) ABDH, (2) ABDH9 } \\
\text { (intermediate GS), (3) Chr3-EST, (4) } \\
\text { Chr3-EST (intermediate GS); M: (1) } \\
\text { ABDH9 [ + GS + pathological T-stage + } \\
\text { margin status], (2) Chr3-EST [ + GS + } \\
\text { pathological T-stage + margin status] }\end{array}$ & 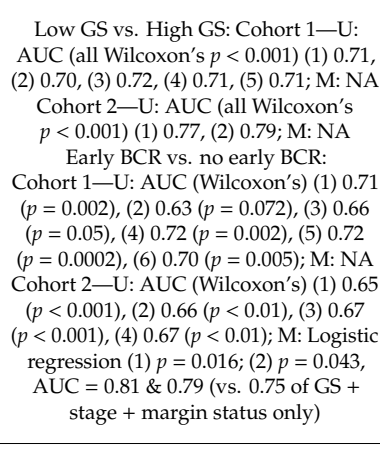 \\
\hline \multicolumn{10}{|c|}{ 2. Enhanced Reduced Representation Bisulphite Sequencing } \\
\hline Lin et al. [121] & $\begin{array}{l}\text { Indolent (localised } \\
\text { disease, no recurrence) vs. } \\
\text { Advanced (aggressive } \\
\text { CRPC) PCa }\end{array}$ & $\begin{array}{c}n=7 \text { indolent, } \\
n=6 \\
\text { advanced }\end{array}$ & $\begin{array}{c}\text { Indolent } \\
\text { (range) } \\
5-6 \text { years }\end{array}$ & $\begin{array}{l}\text { Indolent vs. } \\
\text { aggressive } \\
\text { PCa }\end{array}$ & $\begin{array}{l}n=16 \text { indolent } \\
n=8 \text { advanced }\end{array}$ & $\begin{array}{l}\text { MassARRAY } \\
\text { EpiTYPER }\end{array}$ & $\begin{array}{l}\text { Indolent } \\
3-7 \text { years }\end{array}$ & $\begin{array}{c}\text { Panel of 13 CpG islands: KCNC2, } \\
\text { ZDHHC1, TBX1, CAPG, RARRES2, } \\
\text { GRASP, SAC3D1, TPM4, GSTP1, } \\
\text { NKX2-1, FAM107A, SLC13A3, FILIP1L } \\
\text { U: Panel } \\
\text { M: Not conducted }\end{array}$ & $\begin{array}{c}\text { U: AUC }=0.975(\text { Sensitivity }=95 \% \\
\text { Specificity }=95 \%) \\
\text { M: NA }\end{array}$ \\
\hline \multicolumn{10}{|c|}{ Capture-based methylation sequencing platforms } \\
\hline & & & & MBD (methyl & EpG binding domain)-is & blated genome sec & rencing (MiGS) & & \\
\hline Bhasin et al. [122] & $\begin{array}{l}\text { Low GS (6) vs. High GS } \\
\qquad(8-10)\end{array}$ & $\begin{array}{l}n=6 \text { Low GS, } \\
n=9 \text { High GS }\end{array}$ & $\mathrm{NA}$ & $\begin{array}{l}\text { Low GS vs. } \\
\text { High GS }\end{array}$ & $\begin{array}{c}n=46 \text { Low GS, } \\
n=203 \mathrm{High} \mathrm{GS} \\
(\mathrm{TCGA})\end{array}$ & $\begin{array}{l}\text { HM450K } \\
\text { Microarray }\end{array}$ & NA & $\begin{array}{l}\text { U: } 101 \text { DMRs including at CD14, } \\
\text { PCDHGA11, EYA1, CCDC } 8, H O X C 4 ; \mathrm{M}: \\
\text { not conducted }\end{array}$ & $\begin{aligned} \text { U: LIMMA } p=2.81 \times 10^{28}-0.05 \text { (range) } \\
\text { M: NA }\end{aligned}$ \\
\hline
\end{tabular}


Table 2. Cont.

\begin{tabular}{|c|c|c|c|c|c|c|c|c|c|}
\hline Study $[\operatorname{Ref}]^{a}$ & Approach (Discovery) & $\begin{array}{l}\text { Cohort Size } \\
\text { (Discovery) }\end{array}$ & $\begin{array}{c}\text { Follow-Up } \\
\text { (Discovery) } \\
\text { [Years] }\end{array}$ & $\begin{array}{l}\text { Approach } \\
\text { (Validation) }\end{array}$ & $\begin{array}{l}\text { Cohort Size } \\
\text { (Validation) }\end{array}$ & $\begin{array}{c}\text { Method } \\
\text { (Validation) }\end{array}$ & $\begin{array}{c}\text { Follow-Up } \\
\text { (Validation) } \\
\text { [Years] }\end{array}$ & Final Markers Identified (Validation) & Key Results (Validation) $\mathrm{g}$ \\
\hline \multicolumn{10}{|c|}{ Microarray-based platforms } \\
\hline \multicolumn{10}{|c|}{ 1. Agilent Human CpG Island Microarray } \\
\hline \multirow[t]{5}{*}{ Kron et al. [123] } & $\begin{array}{l}\text { Low GS }(6(3+3)) \text { vs. } \\
\text { High GS }(8(4+4))\end{array}$ & $\begin{array}{c}n=10 \text { Low } \\
\text { GS, } \\
n=10 \mathrm{High} \\
\mathrm{GS}\end{array}$ & NA & $\begin{array}{l}\text { 1. Low GS vs. } \\
\text { High GS }\end{array}$ & $\begin{array}{c}n=20 \text { low GS vs. } n= \\
19 \text { high GS } \\
\text { (MethyLight) }\end{array}$ & MethyLight & NA & $\begin{array}{c}\text { U: HOXD3 (detected in } n=2 \text { GS6 vs. } n \\
=6 \text { GS8); } \\
\text { M: not conducted }\end{array}$ & $\begin{array}{l}\text { Sample size too low for statistical U: } \\
17.3 \% \text { difference in methylation } \\
\text { M: NA }\end{array}$ \\
\hline & & & & $\begin{array}{l}\text { 2. Kron et al. } \\
{[124]} \\
\text { GS } \leq 6 \text { vs. GS7 } \\
\text { BCR }\end{array}$ & $\begin{array}{c}n=232 \\
(n=101 \mathrm{GS} \leq 6, \\
n=107 \mathrm{GS} 7, n=147 \\
\text { no BCR, } \\
n=85 \mathrm{BCR})\end{array}$ & MethyLight & $\begin{array}{l}\text { Mean (range): } \\
4.4(0.2-9.5)\end{array}$ & $\begin{array}{c}\text { GS } \leq 6 \text { vs. GS7-U: HOXD3; M: not } \\
\text { conducted } \\
\text { BCR-U: HOXD3; M: HOXD } 3 x \\
\text { pathological T-stage interaction term [+ } \\
\text { GS + pathological T-stage + margin } \\
\text { status] }\end{array}$ & $\begin{array}{c}\text { GS } \leq 6 \text { vs. GS7-U: } 10.1 \% \text { difference in av. } \\
\text { PMR values, Mann-Whitney U test } \\
p<0.001 \text {; M: NA } \\
\text { BCR-U: Log-rank } p=0.043 ; \text { M: HOXD3 } \\
\text { x pT3a [HR } 3.78(1.09-13.17), p=0.037] \\
\text { HOXD3 x pT3b/pT4 [HR } 5.23 \\
(1.31-20.96), p=0.019]\end{array}$ \\
\hline & & & & $\begin{array}{l}\text { 3. Liu et al. } \\
\text { [125] } \\
\text { GS } \leq 6 \text { vs. GS7 } \\
\text { BCR }\end{array}$ & $\begin{array}{c}n=219 \\
(n=138 \mathrm{GS} \leq 6, \\
n=98 \mathrm{GS} 7 \\
n=\text { ns BCR) } \\
\text { (reduced cohort from } \\
\text { Kron et al. [124]) }\end{array}$ & MethyLight & ns & 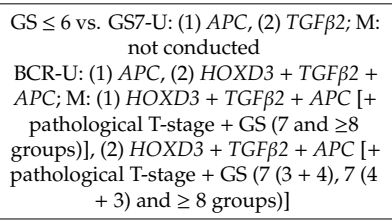 & $\begin{array}{c}\text { GS } \leq 6 \text { vs. GS7-U: Mann-Whitney U test } \\
\text { (1) } p=0.018, \text { (2) } p=0.028 ; \mathrm{M}: \mathrm{NA} \\
\text { BCR-U: Log-rank (1) } p=0.028,(2) \\
p<0.001 ; \mathrm{M}:(1) \mathrm{HR} 2.01(1.14-3.35) \\
p=0.017,(2) \mathrm{HR} 2.068(1.155-3.704), \\
p=0.014\end{array}$ \\
\hline & & & & $\begin{array}{l}\text { 4. Jeyapala et } \\
\text { al. [126] } \\
\text { BCR }\end{array}$ & $\begin{array}{l}\text { Cohort 1: } \\
n=435 \\
n=43 \text { BCR }\end{array}$ & $\begin{array}{l}\text { Cohort 1: } \\
\text { HM450K } \\
\text { Microarray } \\
\text { (TCGA) }\end{array}$ & $\begin{array}{l}\text { Mean (range): } \\
\text { Cohort 1: } 1.9 \\
(0-12.6)\end{array}$ & $\begin{array}{l}\text { Cohort 1-U: GBX2; } \\
\text { M: not conducted }\end{array}$ & $\begin{array}{c}\text { Cohort 1-U: Mann-Whitney Test } \\
\text { cg09094860 [p=0.003], cg00302494 } \\
{[p=0.01] ;} \\
\text { M: not conducted }\end{array}$ \\
\hline & & & & & $\begin{array}{c}\text { Cohort 2: } \\
n=254(n=202, n= \\
52 \mathrm{BCR}, n=58 \\
\text { IDC/C-positive, } n= \\
\text { 196 IDC/C-negative) }\end{array}$ & $\begin{array}{l}\text { Cohort 2: } \\
\text { MethyLight }\end{array}$ & $\begin{array}{l}\text { Cohort 2: } 5.7 \\
(0.1-12.3)\end{array}$ & $\begin{array}{c}\text { Cohort 2-U: GBX2 (and in } \\
\text { IDC/C-negative patients only); } \\
\text { M: (1) GBX2 [+ GS + Pathological } \\
\text { T-stage + pre-op PSA], 2) GBX2 [+ } \\
\text { pre-op PSA] }\end{array}$ & $\begin{array}{c}\text { Cohort 2-U: Mann-Whitney Test } \\
p=0.0001 \text {, IDC/C-negative patients: } \\
\text { Log-rank } p=0.002 ; \\
\text { M: (1) HR 1.02 (1.006-1.034), } p=0.004 \\
\text { (2) C-index } 0.78 \text { (vs. } 0.71 \text { for PSA alone) }\end{array}$ \\
\hline
\end{tabular}


Table 2. Cont.

\begin{tabular}{|c|c|c|c|c|c|c|c|c|c|}
\hline Study [Ref] ${ }^{a}$ & Approach (Discovery) & $\begin{array}{l}\text { Cohort Size } \\
\text { (Discovery) }\end{array}$ & $\begin{array}{c}\text { Follow-Up } \\
\text { (Discovery) } \\
\text { [Years] }\end{array}$ & $\begin{array}{c}\text { Approach } \\
\text { (Validation) }\end{array}$ & $\begin{array}{l}\text { Cohort Size } \\
\text { (Validation) }\end{array}$ & $\begin{array}{c}\text { Method } \\
\text { (Validation) }\end{array}$ & $\begin{array}{c}\text { Follow-Up } \\
\text { (Validation) } \\
\text { [Years] }\end{array}$ & Final Markers Identified (Validation) & Key Results (Validation) $\mathrm{g}$ \\
\hline & & & & $\begin{array}{l}\text { 5. Jeyapala et } \\
\text { al. [127] } \\
\text { BCR } \\
\text { salvage } \\
\text { RT/hormone } \\
\text { therapy }\end{array}$ & $\begin{array}{c}\text { Cohort } 1: \\
n=254(n=202 \mathrm{no} \\
\mathrm{BCR}, n=52 \mathrm{BCR}, n= \\
205 \text { no salvage RT, } n \\
=42 \text { salvage RT, } n= \\
226 \text { no hormone } \\
\text { therapy, } n=21 \\
\text { hormone therapy) } \\
\text { Cohort } 2: \\
n=199(n=159 \mathrm{no} \\
\mathrm{BCR}, n=40 \mathrm{BCR}, n= \\
180 \text { no salvage RT, } n= \\
19 \text { salvage RT, } n=177 \\
\text { no hormone therapy, } \\
n=22 \text { hormone } \\
\text { therapy) }\end{array}$ & MethyLight & 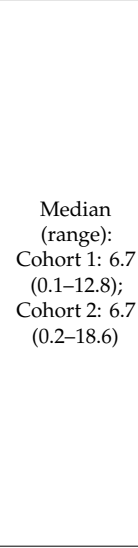 & $\begin{array}{l}\text { 4-G model: HOXD3, TGFß2, CRIP3, } \\
\text { APC (candidate) } \\
\text { Cohort 1 } \\
\text { BCR-U: 4-G model; M: Integrative } \\
\text { model = 4-G model [ I CAPRA-S] } \\
\text { Salvage RT/hormone therapy: U: 4-G } \\
\text { model; M: Integrative model } \\
\text { Cohort 2 } \\
\text { BCR-U: 4-G model; M: Integrative } \\
\text { model } \\
\text { Salvage RT/hormone therapy: U: 4-G } \\
\text { model; M: Integrative model }\end{array}$ & 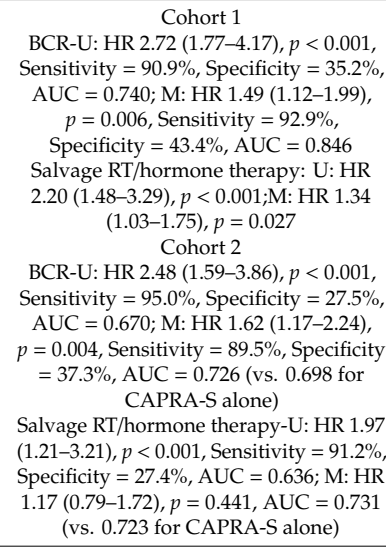 \\
\hline & & & & $\begin{array}{l}\text { 6. Savio et al. } \\
\text { [128] } \\
\text { BCR; } \\
\text { Late BCR (5 } \\
\text { and 7 yrs } \\
\text { post-RP) } \\
\text { salvage } \\
\text { RT/hormone } \\
\text { therapy } \\
\text { [Biopsy } \\
\text { specimens } \\
\text { pre-RP] }\end{array}$ & $\begin{array}{c}n=86 \\
(n=61 \text { no BCR, } n= \\
25 \mathrm{BCR}, n=75 \text { no } \\
\text { salvage } \mathrm{RT}, n=11 \\
\text { salvage } \mathrm{RT}, n=70 \text { no } \\
\text { hormone therapy, } n= \\
15 \text { hormone therapy) }\end{array}$ & MethyLight & $\begin{array}{c}\text { Median } \\
\text { (range): } 5.1 \\
(0.1-16)\end{array}$ & $\begin{array}{l}\text { BCR-U: none; M: 4-G model [+ pre-op } \\
\text { PSA] } \\
\text { Late BCR-U: none; M: (1) 4-G model [+ } \\
\text { pre-op PSA] (5 yrs), (2) 4-G model [+ } \\
\text { pre-op PSA] (7 yrs) } \\
\text { Salvage RT/hormone therapy: U: 4-G } \\
\text { model; M: (1) 4-G model [+ pre-op PSA], } \\
\text { (2) 4-G model [+ CAPRA] }\end{array}$ & $\begin{array}{c}\text { BCR: U: non-sig; M: Sensitivity }=78.6 \% \text {, } \\
\text { Specificity = 64.7\%, AUC = } 0.714 \\
\text { Late BCR: U: non-sig; M: (1) Sensitivity } \\
=80 \%, \text { Specificity }=60.5 \%, \text { AUC }=0.705 \\
\text { (vs. 0.667 for PSA alone), (2) Sensitivity } \\
=76.9 \% \text {, Specificity }=62.9 \%, \\
\text { AUC }=0.688 \text { (vs. 0.6 for PSA alone) } \\
\text { Salvage RT/hormone therapy-U: } \\
\text { Sensitivity }=66.7 \% \text {, Specificity }=75 \%, \\
\text { AUC }=0.699 ; \text { M: }(1) \text { Sensitivity }=75 \%, \\
\text { Specificity }=61.1 \% \text {, AUC }=0.699,(2) \\
\text { Sensitivity }=76.9 \% \text {, Specificity }=58.3 \% \text {, } \\
\text { AUC }=0.797\end{array}$ \\
\hline
\end{tabular}


Table 2. Cont

\begin{tabular}{|c|c|c|c|c|c|c|c|c|c|}
\hline Study [Ref] ${ }^{\mathrm{a}}$ & Approach (Discovery) & $\begin{array}{l}\text { Cohort Size } \\
\text { (Discovery) }\end{array}$ & $\begin{array}{c}\begin{array}{c}\text { Follow-Up } \\
\text { (Discovery) } \\
\text { [Years] }\end{array} \\
\end{array}$ & $\begin{array}{l}\text { Approach } \\
\text { (Validation) }\end{array}$ & $\begin{array}{l}\text { Cohort Size } \\
\text { (Validation) }\end{array}$ & $\begin{array}{c}\text { Method } \\
\text { (Validation) }\end{array}$ & $\begin{array}{c}\text { Follow-Up } \\
\text { (Validation) } \\
\text { [Years] }\end{array}$ & Final Markers Identified (Validation) & Key Results (Validation) $\mathrm{g}$ \\
\hline \multicolumn{10}{|c|}{ 2. Illumina GoldenGate Methylation Microarrays } \\
\hline Goh et al. [129] & $\begin{array}{l}\text { Low GS (6) vs. High GS } \\
\quad(8-10) \\
\text { Overall survival }\end{array}$ & $\begin{array}{c}n=87 \\
(n=19 \mathrm{GS} 6, n \\
=48 \mathrm{GS}-10, \\
n=\text { ns death) }\end{array}$ & $\begin{array}{l}\text { Median } \\
\text { (range): } \\
4(0-11.8)\end{array}$ & $\begin{array}{l}\text { GS (6-9) } \\
\text { BCR }\end{array}$ & $\begin{array}{c}n=59 \\
(n=23 \mathrm{GS} 6, n=22 \\
\text { GS } 7, n=13 \mathrm{GS} 8-10 \\
n=18 \text { for BCR } \\
\text { analysis })\end{array}$ & GoldenGate & $\begin{array}{c}\text { No BCR-5 } \\
(1-13)\end{array}$ & $\begin{array}{l}\text { "PHYMA" signature: } 55 \text { probes } \\
\text { targeting CpG loci of } 46 \text { genes, } \\
\text { including at } A L O X 12, P D G F R B \text { which } \\
\text { were selected for functional validation } \\
\text { GS: } \\
\text { U: PHYMA (GS 6-8) } \\
\text { M: not conducted } \\
\text { BCR: } \\
\text { U: none } \\
\text { M: not conducted }\end{array}$ & $\begin{array}{c}\text { GS: } \\
\text { U: Logistic regression } \beta \text {-coefficient }= \\
2.28, p=0.2 \text { (trend) } \\
\text { M: NA } \\
\text { BCR: } \\
\text { U: non-sig } \\
\text { M: NA }\end{array}$ \\
\hline $\begin{array}{l}\text { Angulo et al. } 2016 \\
\text { Urol Int [130] }\end{array}$ & $\begin{array}{c}\bullet \mathrm{BCR} \\
\bullet \text { PCa death }\end{array}$ & $\begin{array}{c}n=26 \text { no BCR, } \\
n=32 \mathrm{BCR}\end{array}$ & $\begin{array}{c}\text { Mean } \pm \text { SD } \\
\text { (range): } \\
6.3 \pm 3 \\
(0.8-13.8)\end{array}$ & No validation & NA & $\mathrm{NA}$ & NA & $\begin{array}{c}\text { Discovery only: } \\
\text { BCR: } \\
\text { U: (1) Gene hypermethylation profile of } \\
\text { cluster 3 patients (including at GSTM2, } \\
\text { GSTP1, RARB, ALOX12, APC, PDGFRB, } \\
\text { SCGB3A1, CFTR, MT1A, PENK, NEU1, } \\
\text { CCNA1, MET, KLK10, RARA, MFAP4, } \\
\text { TERT, TBX1, KAL, MYCL2, (2) MT1A, } \\
\text { (3) ALOX12, (4) GSTMM2, (5) APC, } \\
\text { (6) MYCL2, (7) RARB, (8) GSTM2 + } \\
\text { MCLY2 } \\
\text { M: (1) Gene hypermethylation profile [+ } \\
\text { D'Amico classification]; (2) GSTM2 [+ } \\
\text { ns]; (3) MCLY2 [+ ns] } \\
\text { PCa Death: } \\
\text { U: GSTM2 + MYCL2 } \\
\text { M: not conducted }\end{array}$ & 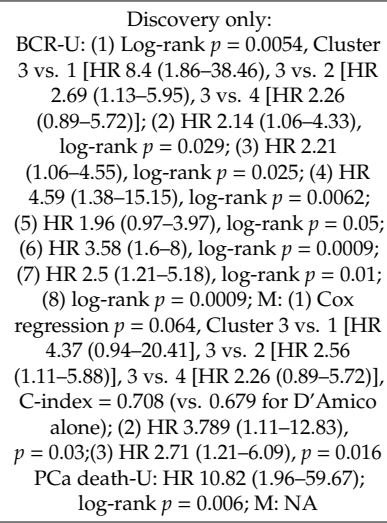 \\
\hline \multicolumn{10}{|c|}{ 3. Illumina Infinium HumanMethylation $27 \mathrm{~K}$ Microarray } \\
\hline $\begin{array}{l}\text { Kobayashi et al. } \\
{[131]}\end{array}$ & $\mathrm{BCR}$ & $n=86$ & $\begin{array}{l}\text { Range: } \\
0-5.5\end{array}$ & No validation & NA & NA & NA & $\begin{array}{c}\text { Discovery only: } \\
\text { U: KCNK4, WDR86, OAS2, TMEM179 } \\
\text { (FDR } \leq 1 \% \text {; hypermethylated) } \\
\text { M: not conducted }\end{array}$ & $\begin{array}{l}\text { Discovery only: } \\
\text { U: ns } \\
\text { M: }\end{array}$ \\
\hline
\end{tabular}


Table 2. Cont.

\begin{tabular}{|c|c|c|c|c|c|c|c|c|c|}
\hline Study $[\text { Ref }]^{a}$ & Approach (Discovery) & $\begin{array}{l}\text { Cohort Size } \\
\text { (Discovery) }\end{array}$ & $\begin{array}{c}\text { Follow-Up } \\
\text { (Discovery) } \\
\text { [Years] }\end{array}$ & $\begin{array}{c}\text { Approach } \\
\text { (Validation) }\end{array}$ & $\begin{array}{l}\text { Cohort Size } \\
\text { (Validation) }\end{array}$ & $\begin{array}{l}\text { Method } \\
\text { (Validation) }\end{array}$ & $\begin{array}{c}\text { Follow-Up } \\
\text { (Validation) } \\
\text { [Years] }\end{array}$ & Final Markers Identified (Validation) & Key Results (Validation) $\mathrm{g}$ \\
\hline $\begin{array}{l}\text { Mahapatra et al. } \\
{[\text { [132] }}\end{array}$ & $\begin{array}{l}\text { Indolent vs. aggressive } \\
\text { disease: } \\
\text { No recurrence vs. } \\
\text { recurrence } \\
\text { BCR vs. clinical } \\
\text { recurrence } \\
\text { Local recurrence vs. } \\
\text { metastatic relapse }\end{array}$ & $\begin{array}{l}n=75 \mathrm{no} \\
\text { recurrence, } n \\
=123 \\
\text { recurrence } \\
n=43 \mathrm{BCR}, n \\
=80 \text { clinical } \\
\text { recurrence } \\
n=44 \text { local } \\
\text { recurrence, } n \\
=36 \\
\text { metastatic } \\
\text { relapse }\end{array}$ & $\begin{array}{c}\text { (Mean } \pm \mathrm{SD} \text { ): } \\
\text { No recurrence } \\
6.2 \pm \pm .5 \\
\text { BCR: } 5.9 \pm 1.4 \\
\text { Local } \\
\text { recurrence: } \\
4.2 \pm 1.7 \\
\text { Metastatic } \\
\text { relapse: } 4.4 \pm \\
4.0\end{array}$ & $\begin{array}{l}\text { Indolent vs. } \\
\text { aggressive } \\
\text { disease: } \\
\text { No recurrence } \\
\text { vs. recurrence } \\
\text { BCR vs. } \\
\text { clinical } \\
\text { recurrence } \\
\text { Local } \\
\text { recurrence vs. } \\
\text { metastatic } \\
\text { relapse }\end{array}$ & $\begin{array}{c}n=20 \text { no recurrence, } \\
n=20 \mathrm{BCR}, \\
n=20 \text { local } \\
\text { recurrence, } \\
n=20 \text { metastatic } \\
\text { relapse }\end{array}$ & $\begin{array}{c}\text { Pyro } \\
\text { sequencing }\end{array}$ & $\begin{array}{c}\text { (Mean } \pm \text { SD) } \\
\text { No } \\
\text { recurrence-6.5 } \\
\pm 1.6 \\
\text { BCR-5.45 } \pm 1.3 \\
\text { Local } \\
\text { recurrence-4. } \\
\pm 1.9 \\
\text { Metastatic } \\
\text { relapse-3.5 } \\
1.9\end{array}$ & $\begin{array}{l}\text { No recurrence vs. recurrence: } \\
\text { U: (1) CRIP1; (2) RUNX3; (3) HS3ST2; } \\
\text { (4) FLNC; (5) RASGRF2 } \\
\text { M: Not conducted } \\
\text { BCR vs. clinical recurrence: U: } \\
\text { (1) PHILDA3; (2) TNFRSFIOD; } \\
\text { (3) RASGRF2 } \\
\text { M: Not conducted } \\
\text { Local vs. metastatic relapse: } \\
\text { U: (1) BCL11B; (2) POUI3F3; (3) RASGRF2 } \\
\text { M: Not conducted }\end{array}$ & 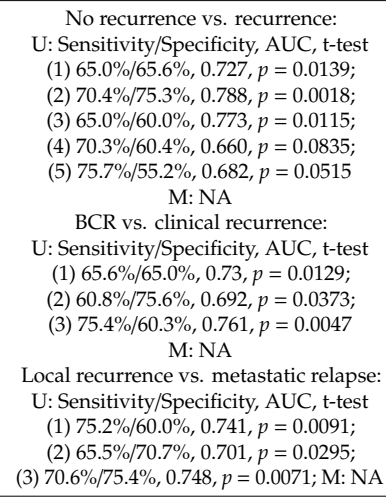 \\
\hline \multicolumn{10}{|c|}{ 4. Illumina Infinium HumanMethylation 450K (HM450K) Microarray } \\
\hline $\begin{array}{l}\text { Geybels et al. } \\
\text { [133] }\end{array}$ & $\begin{array}{c}\text { Low GS ( } \leq 6) \text { vs. High GS } \\
\qquad(8-10)\end{array}$ & $\begin{array}{c}n=65 \text { Low } \\
\text { GS, } n=88 \\
\text { High GS } \\
\text { (TCGA) }\end{array}$ & NA & Progression & $\begin{array}{c}n=323 \text { no } \\
\text { progression, } \\
n=108 \text { progression }\end{array}$ & $\begin{array}{l}\text { HM450K } \\
\text { Microarray }\end{array}$ & $\begin{array}{l}\text { Mean }(\mathrm{SD}): 8.0 \\
\quad(4.2) \text { years }\end{array}$ & 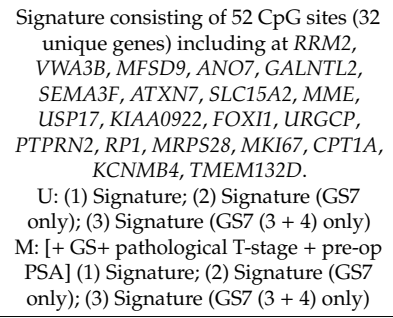 & 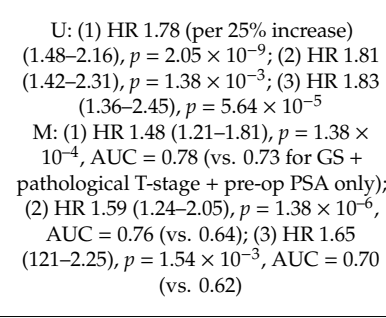 \\
\hline Zhao et al. [134] & $\begin{array}{l}\text { Metastatic-lethal } \\
\text { progression }\end{array}$ & $\begin{array}{l}n=304 \text { no } \\
\text { progression } \\
\text { vs. } n=24 \\
\text { metastatic-lethal }\end{array}$ & $\begin{array}{c}\text { Mean: } \\
\text { Metastatic } \\
\text { relapse-8.1 } \\
\text { Survival-12.2 }\end{array}$ & $\begin{array}{c}1 . \\
\text { Metastatic-lethal } \\
\text { progression }\end{array}$ & $\begin{array}{c}n=41 \text { no progression, } \\
n=24 \\
\text { metastatic-lethal }\end{array}$ & $\begin{array}{l}\text { HM450K } \\
\text { Microarray }\end{array}$ & Mean: 9 & $\begin{array}{c}\text { U: (1) ALKBHH; (2) ATP11A; (3) FHAD1; } \\
\text { (4) KLHL8; (5) PI15; (6) Intergenic region } \\
\text { (chr1); (7) Intergenic (chr16); (8) } \\
\text { Intergenic (chr17) } \\
\text { M: [ + GS] (1) ALKBH5; (2) FHAD1; (3) } \\
\text { KLHL8; (4) PI15 }\end{array}$ & $\begin{array}{c}\text { U: Mean } \beta \text { difference }(t \text {-test), AUC, } \\
\text { pAUC }(1)-5 \%(p=0.037), 0.66 \\
(p=0.035), 0.001(p=0.566) ;(2)-6 \% \\
(p=0.049), 0.66(p=0.03), 0.009 \\
(p=0.022) ;(3)-6 \%(p=0.007), 0.71 \\
(p=0.003), 0.004(p=0.159) ;(4)-10 \% \\
(p=0.002), 0.75(p=0.0004), 0.002 \\
(p=0.359) ;(5)-7 \%(p=0.029), 0.68 \\
(p=0.014), 0.006(p=0.074) ; \\
\text { M: AUC, pAUC, } p \text { (from likelihood ratio } \\
\text { test comparing with model with GS } \\
\text { alone: AUC }=0.816, \text { pAUC }=0.010) \\
\text { (1) } 0.87,0.024, p=0.030 ;(2) 0.86,0.013, \\
p=0.038 ;(3) 0.89,0.008, p=0.014 ; \\
\text { (4) } 0.89,0.006, p=0.026\end{array}$ \\
\hline
\end{tabular}


Table 2. Cont.

\begin{tabular}{|c|c|c|c|c|c|c|c|c|c|}
\hline Study $[\operatorname{Ref}]^{a}$ & Approach (Discovery) & $\begin{array}{l}\text { Cohort Size } \\
\text { (Discovery) }\end{array}$ & 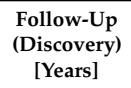 & $\begin{array}{l}\text { Approach } \\
\text { (Validation) }\end{array}$ & $\begin{array}{l}\text { Cohort Size } \\
\text { (Validation) }\end{array}$ & $\begin{array}{c}\text { Method } \\
\text { (Validation) }\end{array}$ & $\begin{array}{c}\text { Follow-Up } \\
\text { (Validation) } \\
\text { [Years] }\end{array}$ & Final Markers Identified (Validation) & Key Results (Validation) $\mathrm{g}$ \\
\hline & & & & $\begin{array}{l}\text { 2. Zhao et al. } \\
\text { [135] } \\
\text { Metastatic-lethal } \\
\text { progression }\end{array}$ & $\begin{array}{l}\text { Training dataset } \\
\text { (from Zhao et al. } \\
\text { [134]): } n=344 \text { no } \\
\text { recurrence, } n=48 \\
\text { metastatic-lethal; } \\
\text { Testing dataset: } n= \\
11 \text { no recurrence, } 23 \\
\text { metastatic-lethal }\end{array}$ & $\begin{array}{c}\text { Pyro } \\
\text { sequencing }\end{array}$ & $\begin{array}{l}\text { Training } \\
\text { (Mean } \\
(\text { minimum) }-8 \\
(5) \\
\text { (5) } \\
\text { At ling } \\
\text { years } 5 \\
\text { years }\end{array}$ & $\begin{array}{l}\text { Methylation score: ALKBH5 + ATP11A + } \\
\text { FHAD1 +KLHL8 + PI15 [+ GS] } \\
\text { Training-U: not conducted; M: } \\
\text { Methylation score } \\
\text { Testing-U: not conducted; } \mathrm{M}: \\
\text { Methylation score }\end{array}$ & $\begin{array}{c}\text { Training-U: NA; M: Logistic regression } \\
\beta \text {-coefficient-ALKBH5 [-0.75], ATP111A } \\
\text { [-0.7], FHAD1 [-9.72], KLHL8 [-0.33], } \\
\text { PI15 [0.70], GS [1.13] } \\
\text { Testing-U: NA; M: Mean difference = } \\
2.49\left(p=6.8 \times 10^{-6}\right) \text {, OR } 4.0(1.8-14.3), \\
p=0.006, \text { AUC }=0.91 \text { (vs. } 0.87 \text { for GS } \\
\text { alone), pAUC }=0.037 \text { (vs. } 0.025 \text { for GS } \\
\text { alone), sensitivity at } 05 \% \\
\text { specificity }=74 \% \text { (vs. } 53 \% \text { for GS alone) }\end{array}$ \\
\hline $\begin{array}{c}\text { Mundbjerg et al. } \\
{[136]}\end{array}$ & $\begin{array}{l}\text { Aggressiveness } \\
\text { (individual PCa foci vs. } \\
\text { matched lymph node } \\
\text { metastasis) }\end{array}$ & $\begin{array}{l}n=14 \text { ( } n=92 \\
\text { samples: } \\
\text { multiple } \\
\text { tumour foci, } \\
\text { adjacent } \\
\text { normal tissue, } \\
\text { lymph node } \\
\text { metastases } \\
\text { and normal } \\
\text { lymph nodes) }\end{array}$ & NA & $\begin{array}{l}\text { Aggressive } \\
\text { (lymph node } \\
\text { metastases } \\
\text { and } \\
\text { pathological } \\
\text { stage T3 } \\
\text { tumours) vs. } \\
\text { non-aggressive }\end{array}$ & $n=351(\mathrm{TCGA})$ & $\begin{array}{l}\text { HM450K } \\
\text { Microarray }\end{array}$ & $\begin{array}{l}\text { Mean: } 3.2 \\
\text { years }\end{array}$ & $\begin{array}{c}\text { Aggressiveness classifier: } 25 \text { probes, } \\
\text { including in NXPH2, NCAPH, TRIB1, } \\
\text { PCDHA1-PCDHA8, C3orf37, C9orf3, } \\
\text { CPN1, TCF7L2, ROBO1, GFPT2, } \\
\text { FBXQ47, SKI, HDACG, CARS, SLC6A17, } \\
\text { BCAT1, GAS1, RAI1 } \\
\text { U: Aggressiveness classifier } \\
\text { M: Not conducted }\end{array}$ & $\begin{array}{c}\text { U: Specificity }=97.4 \% \text {, Sensitivity }= \\
\text { 96.2\%, Negative predictive value }=76 \% \text {, } \\
\text { Positive predictive value }=99.7 \% \text {, } \\
\text { Lymph node metastases [Fishers exact } \\
\text { test } p=9.2 \times 10^{-5} \text { ], pathological stage } \\
\text { T3 [Fishers exact test } p=2.2 \times 10^{-7} \text { ] } \\
\text { M: NA }\end{array}$ \\
\hline Toth et al. [137] & $\begin{array}{l}\text { Good prognosis vs. Poor } \\
\text { prognosis }\end{array}$ & $\begin{array}{c}n=35 \text { good } \\
\text { prognosis, } n= \\
35 \text { poor } \\
\text { prognosis } \\
(80 \% \text { training } \\
\text { set, } 20 \% \\
\text { testing set) }\end{array}$ & Range: $3-5$ & $\begin{array}{l}\text { Good } \\
\text { prognosis vs. } \\
\text { poor } \\
\text { prognosis } \\
\text { (Cohort 1,2) } \\
\text { BCR }(\text { Cohort } \\
1,2,3)\end{array}$ & $\begin{array}{c}\text { Cohort 1: } \\
n=222(n=63 \text { for } \\
\text { prognosis analysis, } n \\
=\text { ns BCR) (ICGC } \\
\text { cohort [138]) } \\
\text { Cohort 2: } \\
n=477(n=27 \text { good } \\
\text { prognosis, } 57 \text { poor } \\
\text { prognosis, } n=\text { ns } \\
\text { BCR) (TCGA) } \\
\text { Cohort 3: } \\
n=12,581(n=3612 \\
\text { BCR) (for ZIC2 } \\
\text { immunostaining } \\
\text { analysis only) }\end{array}$ & $\begin{array}{l}\text { HM450K } \\
\text { Microarray }\end{array}$ & $\begin{array}{l}\text { Cohort } 1 \& 2 \\
\text { At least } 5 \\
\text { years } \\
\text { Cohort } 3 \\
\text { (Median } \\
\text { (range)) } \\
4(0.08-20.08)\end{array}$ & 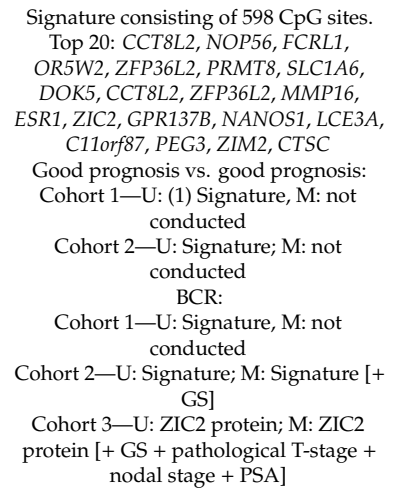 & $\begin{array}{c}\text { Good vs. poor prognosis: } \\
\text { Cohort 1-U: AUC }=0.997 ; \text { M: NA } \\
\text { Cohort 2-U: AUC }=0.775 ; \mathrm{M} \text { : NA } \\
\text { BCR: } \\
\text { Cohort 1-U: Log-rank } p<0.0001 \\
\text { M: NA } \\
\text { Cohort 2-U: Log-rank } p<0.0001 ; \\
\text { M: Cox regression } p=0.0011 \\
\text { Cohort 3-U: Log-rank } p<0.0001 \text {; M: ns }\end{array}$ \\
\hline
\end{tabular}

Abbreviations: AUC = area under the curve; av = average, CAPRA-S = Cancer of the Prostate Risk Assessment Score; CRPC = Castration-Resistant Prostate Cancer; GS = Gleason Score; $\mathrm{HR}=$ hazard ratio; IDC/C = Intraductal Carcinoma and Cribriform Architecture; $\mathrm{M}=$ multivariate analysis; NA = not applicable; non-sig = nonsignificant; $\mathrm{ns}=$ not specified; OR = odds ratio; pAUC = partial area under the cure; $\mathrm{PCa}=$ prostate cancer; $\mathrm{PMR}=$ percent methylated ratio; $\mathrm{PSA}=$ prostate- specific antigen; $\mathrm{RT}=$ radiotherapy; $\mathrm{U}=$ univariate analysis. Definitions: $\mathrm{BCR}$ : Biochemical recurrence: PSA elevations $\geq 0.2 \mathrm{ng} / \mathrm{mL}$ post-RP, except [130] $>0.4 \mathrm{ng} / \mathrm{mL}$ and [131] $>0.07 \mathrm{ng} / \mathrm{mL}$; clinical recurrence $=$ local recurrence or metastatic relapse; good prognosis: organ-confined disease ( $\mathrm{pT}$ ) and lack of BCR for at least 5 years; local recurrence: cancer observed on prostatic bed, confirmed by histological analysis of biopsies; metastatic relapse: metastatic deposits (visceral, bony metastasis) confirmed by positive biopsies or cT/bone scans; metastatic-lethal progression = metastatic relapse or PCa death; pathological T-stage: tumour staging based on pathological examination of surgically removed prostate tissue; PCa death: prostate cancer-specific death; poor prognosis: systemic presence of metastatic disease, indicated by recurrence within 3 years and no response to local radiation therapy; progression: either of BCR, metastatic relapse or PCa death; recurrence: either of BCR, local recurrence or metastatic relapse. ${ }^{a}$ All studies are on prostate cancer tissues from radical prostatectomy, unless specified. ${ }^{b}$ MethylLight is a quantitative methylation-specific PCR (qMSP) platform. ${ }^{c}$ Univariate (U) or Multivariate (M) analyses. d Plus (+) sign indicates variables in the same multivariate model or methylation score together. ${ }^{\text {e }}$ Square bracket ([]) indicate the clinicopathological factors adjusted for in each multivariate model ${ }^{\mathrm{f}}$ The use of bracketed numbers; e.g. (1). (2), indicates different genes, sets of genes or multivariate models validated in the respective study. ${ }^{\mathrm{g}}$ Number in brackets following HR or OR indicate the $95 \%$ confidence interval. ${ }^{\mathrm{h}}$ Bolded headings within the table subdivide the different types of genome-wide platforms (restriction-based, capture-based or microarray-based) used in these studies. 


\subsubsection{Restriction-Based Methylation Sequencing Studies}

The first genome-wide prognostic methylation biomarker discovery study in 2007 used methylation-sensitive arbitrarily primed PCR [139] and methylation CpG island amplification [140] to find markers that could distinguish between patients with high GS $(8-10, n=5)$ vs. those with low GS (2-6 with no grade 4 or 5 patterns; $n=5)$, as well as markers that could predict early BCR following RP ( $n=5$ no BCR ( $>4 \mathrm{yrs}), n=5$ early BCR $(<2$ yrs $)$ [120]. In this approach, methylation-(in)sensitive restriction enzymes were used to digest DNA, and the resulting fragments were screened for methylation differences between patient groups, and sequenced if differences were found. The top 51 markers, along with 11 candidate markers, were validated in two large, independent cohorts, using a custom methylation oligonucleotide microarray (Cohort 1, $n=304$ ) and MethyLight qMSP assays (Cohort 2, $n=233$ ) [120]. GRP7, ABHD9 and Chr3-EST were significantly hypermethylated in high GS patients and could distinguish between no BCR and early BCR, independent of patient GS in Cohort 1 [120]. These associations were validated in Cohort 2, where increased methylation of ABHD9 and Chr3-EST correlated with high-grade disease and early BCR, even after adjusting for GS, pathological T-stage and margin status [120]. A subsequent study reported only univariate associations between $A B H D 9$ methylation and BCR in a larger cohort $(n=605)$ [80], whilst another saw no $A B D H 9$ methylation difference with BCR status $(n=407)$ [141].

A second restriction enzyme-based method used in genome-wide screening is Enhanced Reduced Representation Bisulphite Sequencing (ERRBS) platform. Similarly, ERRBS involves enzymatic digestion of DNA at CpG sites using MspI, followed by size selection and bisulphite sequencing, with the main advantage of enabling single base pair resolution profiling of $\mathrm{CpG}$ sites in GC-rich genomic regions such as promoter $\mathrm{CpG}$ islands [142,143]. Only one study has used this platform, profiling the methylome of a small discovery set of PCa patients, comparing indolent (localised disease with no recurrence; $n=7$ ) vs. advanced cancers (aggressive castration-resistant PCa; $n=6$ ) [121]. A series of differentially methylated CPG islands were identified using linear model analysis, and a prognostic panel of 13 hypermethylated CpG islands (see Table 2) was built using random forest classification. This panel successfully discriminated between indolent and advanced cancers in the validation cohort ( $n=16$ indolent, $n=8$ advanced, MassARRAY EpiTYPER) with an AUC of 0.975 in 10-fold cross validation [121]. Of the genes included in the panel, GSTP1 has been widely studied as a diagnostic and prognostic biomarker of PCa (see above) $[44,45,144]$, whilst GRASP and TPM4 have been previously shown to be differentially methylated in PCa compared to normal prostate tissue [132].

\subsubsection{Capture-Based Methylation Sequencing Studies}

Capture-based DNA methylation sequencing for PCa prognostic studies were first used in 2015. The approach involves the capture of methylated sequences by methyl-CpG binding domain (MBD) protein after shearing of genomic DNA, followed by massive parallel sequencing of enriched sequences $[145,146]$. A limitation of this approach is that it does not provide a single nucleotide resolution, instead identifying regions with multiple methylated CpGs. Only one study has used this method to profile and identify methylation differences between low and high GS tumours ( $n=6$ vs. 9) [122]. They reported hypermethylation of 4932 regions in high-grade disease [122]. Extensive genomic and functional characterisation of these Differentially Methylated Regions (DMRs) were conducted, including comparison with publicly available data from The Cancer Genome Atlas (TCGA) project [147]. This allowed them to validate the association between methylation and high grade disease at 101 DMRs, and show that a subset of these DMRs correlated with gene expression changes that associated with poorer survival in PCa patients, including the CCDC8 and HOXD4 gene [122]. 


\subsubsection{DNA Methylation Microarray Studies}

Microarrays have become the most popular technology for genome-wide DNA methylation profiling for biomarker discovery. For this method, DNA is first treated to enable later distinction between methylated and unmethylated sites (using methylated DNA immunoprecipitation, methylation-specific restriction enzymes or bisulphite-conversion). The DNA is then hybridised to unique oligonucleotide probes of CpGs on arrays, labelled with a fluorescent dye and imaged, and the signal is used to determine single nucleotide resolution CpG methylation. Several DNA methylation microarrays have been produced, including the Agilent Human CpG Island Microarray [148] (237,220 CpGs) (Figure 2) and Illumina DNA methylation microarrays, with successive array updates interrogating a broader range and number of $\mathrm{CpG}$ sites across the genome: GoldenGate Cancer Panel I (1505 CpGs) [149], Infinium HumanMethylation 27K Microarray (HM27K: 27,578 CpGs) [150] and Infinium HumanMethylation 450K Microarray (HM450K: 485,577 CpGs) [151] (Figure 2).

\section{Agilent Human CpG Island Microarray}

An initial genome-wide study in 2009 using the Agilent Human CpG Island Microarray [123] laid the foundation for a number of subsequent validation studies [124-128], leading to the identification of several robust methylation markers with prognostic value. The original study screened for methylation differences between patients with GS $6(n=10)$ and GS $8(n=10)$, finding 493 CpG sites (223 individual genes) that could distinguish between the patient groups. A candidate marker, HOXD3, was selected and assessed in an independent set of samples ( $n=20$ GS6 vs. $n=19$ GS8), validating HOXD3 hypermethylation in GS8 compared to GS6 patients. Further studies investigated HOXD3 [124] and GBX2 [126] as individual markers of progression, using BCR as their outcome of interest. HOXD3 was associated with $\mathrm{BCR}$ in univariate analysis ( $n=147 \mathrm{no} \mathrm{BCR,} n=85 \mathrm{BCR})$, and a methylation score combining HOXD3 with pathological T-stage was found to be an independent predictor of BCR [124]. GBX2 methylation was assessed in methylation data from TCGA ( $n=435$ no BCR, $n=43$ BCR), and in a second cohort ( $n=202$ no BCR, $n=52 \mathrm{BCR}$ ). In both cohorts, associations were observed between $G B X 2$ methylation and $B C R$, with $G B X 2$ methylation shown to have potential as an additive predictor when combined with PSA levels at diagnosis (Cohort 2) [126].

The same research team also investigated HOXD3 in combination with other markers $[125,127]$. One study combined HOXD3, TGF $\beta 2$ (another differentially methylated gene from the original discovery study) and $A P C$, an a priori candidate marker [125]. Using a cohort from an earlier study [124] ( $n=219)$, they found that this multigene panel improved prediction of BCR over any individual markers, and was independent of existing clinicopathological variables [125]. In another study they used a penalized cox regression method to develop a 4-gene (4-G) prognostic model for BCR, consisting of APC, HOXD3, TGFß2 and CRIP3 [127]. The 4-G model associated with BCR as well as progression to post-surgical therapies (hormone and salvage radiotherapy) in two large cohorts (Cohort 1: $n=202$ no BCR, $n=52$ BCR; Cohort 2: $n=159, n=40$ BCR) [127]. Most recently, the prognostic ability of the 4-G model was investigated in presurgery prostate biopsy specimens ( $n=61$ no BCR, $n=25 \mathrm{BCR})$ [128]. The 4-G methylation panel was able to prognosticate BCR, late recurrence (BCR 5 \& 7 yrs post-RP) and eventual progression to postsurgery treatments [127]. Additionally, a study from another team found strong evidence of HOXD3 hypermethylation in BCR progression ( $n=303$ no BCR, $n=104$ BCR) [141]. These studies provide strong support for HOXD3 hypermethylation as a robust marker for BCR progression. Further studies examining the prognostic utility of HOXD3 and other genes in the panel are warranted, particularly in cohorts with more clinically relevant endpoints for aggressive disease, such as metastatic relapse and PCa death.

\section{GoldenGate Cancer Panel I Microarray Platform}

Between 2014 and 2016, two research groups published studies using Illumina's GoldenGate Cancer Panel I Microarray platform to identify novel biomarkers for disease risk. In the first study, 
a Support Vector Machine was used to build a classification model, generating a signature consisting of 55 probes across 46 genes (including ALOX12, PDGFRB) [129]. The signature, termed "PHYMA", was able to distinguish between low and high GS tumours, and a high PHYMA score associated with poorer survival outcome (adjusted for clinical T-stage and GS) $(n=87)$. Trending associations between PHYMA score and GS, but not BCR, was observed in a separate cohort $(n=59)$ [129]. The second study using the GoldenGate Cancer Panel reported that a gene hypermethylation profile based on hierarchical clustering of patients (see Table 2 for details), as well as hypermethylation at individual markers GSTM2 and MCLY2, independently predicted BCR risk. The concurrent methylation of the two markers was also associated with PCa death, however no further validation of the study findings in a separate independent cohort was conducted [130].

\section{HM27K Platform}

Two studies published in 2011-2012 used the HM27K Microarray platform for prognostic discovery biomarker studies of PCa. One study $(n=86)$ reported increased methylation at 4 CpGs $(K C N K 4$, WDR86, OAS2, TMEM179) in patients with a shorter time to BCR, although no further validation of these markers was conducted [131]. Another study performed a number of binary comparisons of methylation levels: no recurrence $(n=75)$ vs. recurrence (BCR or clinical recurrence (local recurrence or metastatic relapse), $n=123)$; BCR $(n=43)$ vs. clinical recurrence $(n=80)$; and local $(n=44)$ vs. metastatic relapse $(n=36)$. The discovery analysis found 75,16 and 68 genes significantly methylated in each analysis, respectively. Several markers from each group of analyses were assessed by pyrosequencing in 80 patients ( $n=20$ per clinical endpoint), validating many of the nominated candidate genes (see Table 2 for details), including RUNX3, a candidate gene previously studied in a priori prognostic biomarker studies [79,82].

\section{HM450K Platform}

The HM450K extended the HM27K probe design to provide coverage of a more diverse set of genomic categories and regions [150,151]. The platform has been widely used for prognostic biomarker discovery (since 2016) and in the generation of publicly available data, including the TCGA dataset of nearly 500 PCa methylomes, which is commonly used by researchers for biomarker discovery or validation [147]. A study by Geybels et al. used TCGA HM450K methylation data to identify methylation differences between PCa patients with low GS $(\leq 6, n=65)$ vs. high GS $(8-10, n=88)$ [133]. The elastic net method was used to build a signature consisting of $52 \mathrm{CpG}$ sites across 32 genes, many of which were novel prognostic candidates. The signature was then tested in HM450K data from a larger validation cohort $(n=523)$ for its ability to predict disease progression (any of BCR, metastases and/or PCa death) and was found to be an independent predictor of progression in multivariate analysis including GS, pathological T-stage and diagnostic PSA level in all patients, and in a subset of GS 7 patients [133]. Another study from the same lab used the HM450K data from 430 primary PCa tissues, to identify 42 DNA methylation biomarkers that could predict the more serious endpoint of metastatic-lethal progression [134]. In total, eight of these CpG sites validated in a small validation cohort ( $n=65$, HM450K), with methylation at four of these sites observed to complement GS in discriminating between nonrecurrent and metastatic-lethal patients [134]. A follow-up study by the same research group used pyrosequencing to technically validate five of the eight differentially methylated CpG sites (in ALKBH5, ATP11A, FHAD1, KLHL8, PI15) [135]. They then used a training cohort $(n=392)$ to build a model, based on the five sites, from which they calculated a prognostic methylation score for prediction of metastatic-lethal progression. In a multivariate model with GS, a four-fold increase in risk of metastatic-lethal progression was reported in the testing cohort $(n=34)$, for each unit increase in the methylation score, and the methylation score outperformed prediction by GS alone [135].

A novel approach by Mundbjerg and colleagues used the HM450K to profile multiple samples per patient (different tumour foci, adjacent normal tissue, lymph node metastases and normal lymph 
nodes) from a cohort of patients who had undergone RP for multifocal disease ( $n=14$ patients, $n=92$ samples). They then used a GLMnet algorithm to categorise the aggressiveness of individual PCa foci based on how well they matched the methylation profile of the lymph node metastasis. The resulting aggressiveness classifier consisted of $25 \mathrm{CpG}$ sites (including in NXPH2, TRIB1 and PCDHA1-PCDHA8), and was successfully validated in the TCGA cohort $(n=351)$ through accurate prediction of lymph node metastases and invasive pathological stage T3 tumours [136]. Finally, the most recent HM450K study which aligns with our criteria of prognostic discovery, used random-forest-based modelling to identify markers that could differentiate between good prognosis, defined as organ-confined disease (pT2) and no BCR for at least 5 years $(n=35)$, and poor prognosis, defined as systemic metastatic disease with recurrence within 3 years $(n=35)$ [137]. A DNA methylation-based classifier consisting of 598 sites was developed, validating in two independent cohorts of patients with publicly available methylation data, based on the same selection criteria (ICGC cohort $n=63$, TCGA cohort: $n=84$ ) [137]. Further analyses highlighted the independent prognostic value of a gene overlapping one of the 598 sites, with immunostaining analysis reporting significant association between loss of ZIC2 protein expression and poorer prognosis (adjusted for GS, pathological T- stage, nodal stage and PSA) [137].

In summary, technological advances now mean that many hundreds of thousands of $\mathrm{CpG}$ sites can be profiled simultaneously, which has provided a more complete view of the complexity and heterogeneity of the PCa methylome. This has enabled the discovery of more accurate and novel biomarkers for PCa prognosis that aid or outperform existing clinicopathological factors. These range from individual markers (e.g., ABHD9, HOXD3, GBX2, RASGRF2) to methylation signatures (e.g., 4-G model, PHYMA). However, with an average follow-up of just approximately 5 years across the studies, most focus on short-term clinical endpoints such as BCR. To discover and validate novel DNA methylation biomarkers for the most important clinical endpoints of metastasis and PCa specific mortality, further research needs to be conducted on large independent cohorts with extensive long-term follow-up data ( $\geq 15$ years) [16]. Furthermore, the genome-wide methods described above are still limited in the number of $\mathrm{CpGs}$ assessed (Figure 2), and have a strong bias towards targeting methylation in CG rich regions of gene promoter and CpG islands [145]. More recent techniques, such as Illumina's EPIC microarray, cover more distal regulatory genomic regions [151], and the 'gold standard' Whole Genome Bisulphite Sequencing (WGBS) technique can profile all approximately 28 million CpGs in the methylome [152] (Figure 2). An expanded search of the methylome will enable comprehensive discovery of novel biomarkers for PCa prognosis.

\section{Non-Invasive Detection of Prognostic DNA Methylation Markers in Liquid Biopsies}

There is widespread interest in using 'liquid biopsies' as a minimally invasive means to improve the accuracy and safety of cancer diagnosis, risk-stratification and disease monitoring. Liquid biopsies include bodily fluids, such as blood, urine, saliva and cerebrospinal fluid, which can be sampled for the presence of circulating tumour cells, cell-free (cf) DNA (released from tumour cells by apoptosis, necrosis and active secretion) and tumour-secreted exosomes containing RNAs, DNAs and proteins. A liquid biopsy offers the opportunity to gain a more comprehensive profile of the heterogeneous molecular landscape of the tumour at diagnosis and during tumour evolution over the course of the disease and treatment. This is particularly relevant in $\mathrm{PCa}$, as the majority of patients have multifocal disease, meaning that the information from a single tissue biopsy may not reflect the dynamics of all tumour foci in the prostate, which can have variable aggressiveness and progression [136].

DNA methylation biomarkers are particularly pertinent in the liquid biopsy setting. In contrast to the limited number of recurrent genetic mutations in cancer, aberrant DNA methylation events tend to be tissue and cancer-type specific and occur across larger genomic regions, allowing DNA methylation to be easily targeted for measurement [153]. The recent development of new technologies has greatly contributed to the ability to sensitively measure DNA methylation [55]. This is highly relevant in liquid biopsy samples where tumour DNA may be present at very low concentrations i.e., $<0.01 \%$ of the total DNA content $[154,155]$. For example, GSTP1 hypermethylation, one of the most common 
epigenetic events in PCa tumour specimens, has been readily detected in liquid biopsy samples from PCa patients, such as urine, semen, blood serum and plasma samples [156].

\subsection{Urine-Based Methylated Biomarkers}

Early studies showed the detection of GSTP1 methylation in urine from patients with PCa; however diagnostic sensitivity was poor (less than 30\%) [157]. Expanding the panel to a three-gene signature (GSTP1, APC and RARB) improved sensitivity to 60\% [158]. More recently a six-gene methylation panel has been developed, termed 'Epigenetic Cancer of the Prostate Test in Urine' (epiCaPture), which targets GSTP1, SFRP2, IGFBP3, IGFBP7, APC and PTGS2 [159]. epiCaPture was applied to urine samples of men with PCa and showed significant associations between DNA methylation and disease aggressiveness, with AUC of 0.64, 0.86 and 0.83 for detecting PCa, high-grade PCa, and high-risk PCa, respectively. Overall, the study concluded that epiCaPture can accurately determine risk compared to two widely used risk stratification systems, D'Amico [26] and CAPRA [160]. In another study, a two-gene methylation panel (HOXD3 and GSTP1) was developed called Prostate Cancer Urinary Epigenetic (ProCUrE) [161]. When applied to urine samples, the positive predictive value of this panel was $59.478{ }^{\circ} \mathrm{C} \%$, higher than PSA $(38.2-72.1 \%)$, for all risk category comparisons. In addition, Moreira-Barbosa et al. assessed methylation of two different gene panels comprising ( $m i R 1-93 b / m i R 3-4 b / c)$ and $(A P C, G S T P 1, R A R B)$ in tissue and urine; they showed that a combination of methylation measurements from the two panels in urine independently predicted shorter disease-specific survival [162]. Hypermethylation of the RASSF1 promoter has also been reported for its prognostic value as a urine-based methylated biomarker [93]. In this study, a multivariate model of RASSF1 methylation together with pathological T-stage was the most significant predictor of BCR in patients (GS 6) in both tissue and urine samples [93]. Overall, these studies highlight the potential of DNA methylation as a urine-based prognostic biomarker in PCa.

\subsection{Blood-Based Methylated Prognostic Biomarkers For cfDNA Testing}

In cancer patients, a proportion of circulating cfDNA is derived from tumour cells, i.e., circulating tumour DNA (ctDNA). cfDNA can be isolated from blood plasma or serum and is present at very low concentrations, ranging from approximately $0-50 \mathrm{ng} / \mathrm{mL}$ in healthy individuals; in cancer patients, the proportion of ctDNA can vary between $0.01 \%$ to more that $90 \%$ of the cfDNA.

A number of studies have shown that methylated GSTP1 in circulating cfDNA has prognostic value [163-165]; for example, Mahon and colleagues showed that GSTP1 methylation in cfDNA was associated with overall survival and response to chemotherapy in men with advanced PCa [164]. Importantly, this study demonstrated that GSTP1 methylation levels prior to and after one chemotherapy cycle were stronger predictors of overall survival than changes in PSA levels at 3 months post-chemotherapy. More recently, Hendriks and colleagues reported hypermethylation of GSTP1 and $A P C$ in plasma cfDNA, together with the concentration of cfDNA, to be statistically significant as a prognostic biomarker for overall survival in castration-resistant PCa [166]. Further cfDNA studies report the prognostic utility of GSTP1 methylation in combination with other frequently methylated genes; for example, GSTP1 and RASSF2A methylation [59] and GSTP1, RASSF1 and RARB methylation [167].

Other genes have shown promise as prognostic methylation biomarkers in cfDNA in PCa. Horning and colleagues showed that promoter hypermethylation of SRD5A 2 and CYP11A 1 was associated with BCR and poorer prognosis [168]. In another study, cfDNA methylation of the $A P C$, GSTP1, RASSFI, MDRI and PTGS2 genes was associated with overall survival time in men with advanced PCa [60]. Additionally, MSP on a cohort of $n=117$ patient serum samples showed that PCDH8 methylation was an independent predictive risk factor for BCR-free survival $(p<0.007)$ in low GS (<7) PCa patients after surgery [169]. Overall, these studies highlight the potential value of DNA methylation biomarkers in cfDNA as prognostic indicators of relapse. 


\section{Conclusions and Future Directions}

Research over the last two decades has shown the potential of DNA methylation as a biomarker for PCa prognosis. DNA methylation biomarker discovery has accelerated rapidly with the emergence of affordable, scalable, whole-genome profiling techniques. However, the ongoing technological advancements are bringing new analytical challenges, such as establishing the best way to aggregate methylation data across genomic regions, control for multiple tests; combine methylation with other 'omic' data types and select and prioritise the most important prognostic features from which to build predictive models [170]. A number of new analytical approaches have been made to address these issues (for example, [171-175]) Given the ever-increasing sophistication of technologies, and thus growing number of high-dimensional datasets, bioinformatic method development will continue to be a high-priority research area.

Even with the most sophisticated laboratory and bioinformatic tools for biomarker discovery, the ultimate test of whether a prospective methylation biomarker is prognostic is through validation in multiple, appropriately sized, independent cohorts. One of the obstructions to validation, and therefore translation of new DNA methylation biomarkers to the clinic, is the dearth of suitable, publicly available methylation datasets with adequate clinical follow-up data. Indeed, the flagship TCGA PCa methylation dataset has only short-term follow-up clinical data, and so cannot be used to fully assess the prognostic value of putative methylation biomarkers. For existing methylation datasets such as this, their utility for prognostic research would be increased through the continued collection of long-term follow-up data.

A notable problem is that studies frequently use the same few public cohorts for discovery and/or validation, which may be leading to biased results across the field. To advance the field, new PCa methylation public datasets need to be generated. An emphasis should be placed on using the very latest laboratory techniques which allow for full genome screening, such as the comprehensive EPIC microarray or WGBS, which will increase the likelihood of identifying novel biomarker regions. Another limitation in this field is the predominant focus on using Caucasian or European ancestry based populations, with only a handful of studies to date investigating non-Caucasian patients $[96,176]$. More ethnically diverse populations need to be investigated for discovery of population-specific prognostic markers, as well as examining how well promising biomarkers found in Caucasian populations translate across other ethnicities. Many of the highest impact journals now have an open data policy. Going forward, this open data ethos should be adopted by more researchers and publications, as it not only provides new resources for other researchers to use in their validation efforts, but also allows transparency in the research method, which ultimately improves the quality of research in the field overall.

Finally, we have discussed the advances in noninvasive DNA methylation prognostic biomarker research. Looking ahead, clinical translation of this research will be a priority as liquid biopsies offer a number of advantages over tissue-based methods, such as reducing side-effects like infection and surgical complications $[17,18]$, and allowing serial collection of samples during the course of monitoring or therapy to provide opportunities for timely therapeutic interventions [177]. This should be paired with the utilisation of DNA methylation assays suitable for application in clinical settings (for example, Multiplex Bisulfite PCR Sequencing $[178,179]$ ) which are cost-effective, scalable, reproducible and capable of sensitively detecting methylated tumour DNA in limited clinical material such as liquid biopsies. In conclusion, DNA methylation shows great potential as a prognostic biomarker and could thus transform the clinical management of PCa patients. Key to the successful implementation of prognostic biomarkers is the ability to apply them in diagnostic samples, such as needle biopsy or liquid biopsy samples. Ultimately, the development of specific guidelines for clinical use still requires extensive validation of the best candidate genes in a range of tissue types in independent cohorts with long-term follow-up, for determination of methylation level cut-offs and prognostic validation. 
Author Contributions: D.L., S.C., R.P. and C.S. all contributed to the writing of the manuscript. All authors have read and agreed to the published version of the manuscript.

Funding: This work is supported by the National Health and Medical Research Council (NHMRC) project grants (1128912-S.J.C., C.S.; 1106870-SJC, R.P.) and NHMRC fellowships (1063559 and 1156408-S.J.C.); Cancer Council NSW (RG1-18-09-RP, S.J.C.), Cancer Institute of New South Wales Fellowship (CINSW) to R.P. (14/ECF/1-23), CINSW Translational Program Grant \# TPG172146 (S.J.C.). The contents of the published material are solely the responsibility of the administering institution and individual authors and do not reflect the views of the NHMRC.

Conflicts of Interest: The authors declare no conflict of interest.

\section{Abbreviations}

$\begin{array}{ll}\text { AUC } & \text { Area Under the Curve } \\ \text { BCR } & \text { BioChemical Recurrence } \\ \text { CAPRA } & \text { Cancer of the Prostate Risk Assessment } \\ \text { CF } & \text { Clinical Failure } \\ \text { cfDNA } & \text { circulating cell-free DNA } \\ \text { COBRAc } & \text { COmbined Bisulphite Restriction Analysis } \\ \text { ctDNA } & \text { circulating tumour DNA } \\ \text { ddPCR } & \text { Droplet Digital PCR } \\ \text { Df } & \text { Degrees of freedom } \\ \text { DMR } & \text { Differentially Methylated Regions } \\ \text { ERRBS } & \text { Enhanced Reduced Representation Bisulphite Sequencing } \\ \text { FFPET } & \text { Formalin-Fixed Paraffin-Embedded Tissue } \\ \text { GS } & \text { Gleason Score } \\ \text { HM27K } & \text { Infinium HumanMethylation 27K Microarray } \\ \text { WGBS } & \text { Whole Genome Bisulphite Sequencing } \\ \text { HM450K } & \text { Infinium HumanMethylation 450K Microarray } \\ \text { HR } & \text { Hazard Ratio } \\ \text { IQR } & \text { InterQuartile Range } \\ \text { LR } & \text { Likelihood Ratio } \\ \text { M } & \text { Multivariate } \\ \text { MBDCap-Seq } & \text { Methyl-CpG Binding Domain Capture sequencing } \\ \text { MSP } & \text { Methylation-Specific PCR } \\ \text { PCa } & \text { Prostate Cancer } \\ \text { PCR } & \text { Polymerase Chain Reaction } \\ \text { PSA } & \text { Prostate-Specific Antigen } \\ \text { qMSP } & \text { quantitative Methylation-Specific PCR } \\ \text { RP } & \text { Radical Prostatectomy } \\ \text { RRBS } & \text { Reduced Representation Bisulphite Sequencing } \\ \text { TCGA } & \text { The Cancer Genome Atlas } \\ \text { TURP } & \text { TransUrethral Resection of the Prostate } \\ \text { U } & \text { Univariate } \\ & \end{array}$

\section{References}

1. Bray, F.; Me, J.F.; Soerjomataram, I.; Siegel, R.; Torre, L.A.; Jemal, A. Global cancer statistics 2018: GLOBOCAN estimates of incidence and mortality worldwide for 36 cancers in 185 countries. CA A Cancer J. Clin. 2018, 68, 394-424. [CrossRef] [PubMed]

2. WHO. GLOBOCAN 2018 Database. Issued by World Health Organization (WHO). Available online: http: //gco.iarc.fr/today (accessed on 1 August 2020).

3. Ferlay, J.E.; Lam, F.; Colombet, M.; Mery, L.; Pineros, M.; Znaor, A.; Soerjomataram, I.; Bray, F. Global Cancer Observatory: Cancer Tomorrow. Available online: https://gco.iarc.fr/tomorrow (accessed on 1 August 2020).

4. Rawla, P. Epidemiology of Prostate Cancer. World J. Oncol. 2019, 10, 63-89. [CrossRef] [PubMed]

5. Culp, M.B.; Soerjomataram, I.; Efstathiou, J.A.; Bray, F.; Jemal, A. Recent Global Patterns in Prostate Cancer Incidence and Mortality Rates. Eur. Urol. 2020, 77, 38-52. [CrossRef] [PubMed] 
6. Litwin, M.S.; Tan, H.-J. The Diagnosis and Treatment of Prostate Cancer. JAMA 2017, 317, $2532-2542$. [CrossRef] [PubMed]

7. Shao, Y.-H.; Demissie, K.; Shih, W.; Mehta, A.R.; Stein, M.N.; Roberts, C.B.; DiPaola, R.S.; Lu-Yao, G.L. Contemporary Risk Profile of Prostate Cancer in the United States. J. Natl. Cancer Inst. 2009, 101, 1280-1283. [CrossRef] [PubMed]

8. Welch, H.G.; Gorski, D.H.; Albertsen, P.C. Trends in Metastatic Breast and Prostate Cancer-Lessons in Cancer Dynamics. N. Engl. J. Med. 2015, 373, 1685-1687. [CrossRef] [PubMed]

9. Howlader, N.; Krapcho, M.; Miller, D.; Brest, A.; Yu, M.; Ruhl, J.; Tatalovich, Z.; Mariotto, A.; Lewis, D.R.; Chen, H.S.; et al. SEER Cancer Statistics Review, 1975-2016. Available online: https://seer.cancer.gov/csr/ 1975_2016/ (accessed on 1 August 2020).

10. Roehl, K.A.; Han, M.; Ramos, C.G.; Antenor, J.A.V.; Catalona, W.J. Cancer Progression and Survival Rates Following Anatomical Radical Retropubic Prostatectomy in 3478 Consecutive Patients: Long-Term Results. J. Urol. 2004, 172, 910-914. [CrossRef] [PubMed]

11. Eggener, S.E.; Scardino, P.T.; Walsh, P.C.; Han, M.; Partin, A.W.; Trock, B.J.; Feng, Z.; Wood, D.P.; Eastham, J.A.; Yossepowitch, O.; et al. Predicting 15-Year Prostate Cancer Specific Mortality After Radical Prostatectomy. J. Urol. 2011, 185, 869-875. [CrossRef]

12. Freedland, S.J.; Humphreys, E.B.; Mangold, L.A.; Eisenberger, M.; Dorey, F.J.; Walsh, P.C.; Partin, A.W. Risk of Prostate Cancer-Specific Mortality Following Biochemical Recurrence After Radical Prostatectomy. JAMA 2005, 294, 433-439. [CrossRef]

13. Abdollah, F.; Boorjian, S.; Cozzarini, C.; Suardi, N.; Sun, M.; Fiorino, C.; Di Muzio, N.; Karakiewicz, P.I.; Montorsi, F.; Karnes, R.J.; et al. Survival Following Biochemical Recurrence After Radical Prostatectomy and Adjuvant Radiotherapy in Patients With Prostate Cancer: The Impact of Competing Causes of Mortality and Patient Stratification. Eur. Urol. 2013, 64, 557-564. [CrossRef]

14. Valicenti, R.K.; Thompson, I.; Albertsen, P.; Davis, B.J.; Goldenberg, S.L.; Wolf, J.S.; Sartor, O.; Klein, E.; Hahn, C.; Michalski, J.; et al. Adjuvant and Salvage Radiation Therapy After Prostatectomy: American Society for Radiation Oncology/American Urological Association Guidelines. Int. J. Radiat. Oncol. 2013, 86, 822-828. [CrossRef] [PubMed]

15. Welch, H.G.; Albertsen, P.C. Prostate Cancer Diagnosis and Treatment after the Introduction of Prostate-Specific Antigen Screening: 1986-2005. J. Natl. Cancer Inst. 2009, 101, 1325-1329. [CrossRef]

16. Albertsen, P.C.; Hanley, J.A.; Fine, J. 20-Year Outcomes Following Conservative Management of Clinically Localized Prostate Cancer. JAMA 2005, 293, 2095-2101. [CrossRef] [PubMed]

17. Steineck, G.; Helgesen, F.; Adolfsson, J.; Dickman, P.W.; Johansson, J.-E.; Norlen, B.J.; Holmberg, L. Quality of Life after Radical Prostatectomy or Watchful Waiting. N. Engl. J. Med. 2002, 347, 790-796. [CrossRef]

18. Wilt, T.J.; Macdonald, R.; Rutks, I.; Shamliyan, T.; Taylor, B.C.; Kane, R.L. Systematic review: Comparative effectiveness and harms of treatments for clinically localized prostate cancer. Ann. Intern. Med. 2008, 148, 435-448. [CrossRef] [PubMed]

19. Thomsen, F.B.; Brasso, K.; Klotz, L.H.; Røder, M.A.; Berg, K.D.; Iversen, P. Active surveillance for clinically localized prostate cancer-A systematic review. J. Surg. Oncol. 2014, 109, 830-835. [CrossRef] [PubMed]

20. Cooperberg, M.R.; Carroll, P.R.; Klotz, L. Active Surveillance for Prostate Cancer: Progress and Promise. J. Clin. Oncol. 2011, 29, 3669-3676. [CrossRef]

21. Klotz, L. Active Surveillance: The Canadian Experience. Manag. Castration Resist. Prostate Cancer 2012, 22, 95-105. [CrossRef]

22. Welty, C.J.; Cooperberg, M.R.; Carroll, P.R. Meaningful end points and outcomes in men on active surveillance for early-stage prostate cancer. Curr. Opin. Urol. 2014, 24, 288-292. [CrossRef]

23. Tolkach, Y.; Kristiansen, G. The Heterogeneity of Prostate Cancer: A Practical Approach. Pathobiology 2018, 85, 108-116. [CrossRef]

24. Prensner, J.R.; Rubin, M.A.; Wei, J.T.; Chinnaiyan, A.M. Beyond PSA: The Next Generation of Prostate Cancer Biomarkers. Sci. Transl. Med. 2012, 4, 127rv3. [CrossRef] [PubMed]

25. Epstein, J.I.; Walsh, P.C.; Carmichael, M.; Brendler, C.B. Pathologic and clinical findings to predict tumor extent of nonpalpable (stage T1c) prostate cancer. JAMA 1994, 271, 368-374. [CrossRef] 
26. D'Amico, A.V.; Whittington, R.; Malkowicz, S.B.; Schultz, D.; Blank, K.; Broderick, G.A.; Tomaszewski, J.E.; Renshaw, A.A.; Kaplan, I.; Beard, C.; et al. Biochemical Outcome After Radical Prostatectomy, External Beam Radiation Therapy, or Interstitial Radiation Therapy for Clinically Localized Prostate Cancer. JAMA 1998, 280, 969-974. [CrossRef]

27. Kattan, M.W.; Eastham, J.A.; Wheeler, T.M.; Maru, N.; Scardino, P.T.; Erbersdobler, A.; Graefen, M.; Huland, H.; Koh, H.; Shariat, S.F.; et al. Counseling Men With Prostate Cancer: A Nomogram for Predicting the Presence of Small, Moderately Differentiated, Confined Tumors. J. Urol. 2003, 170, 1792-1797. [CrossRef]

28. Stephenson, A.J.; Scardino, P.T.; Eastham, J.A.; Jr, F.J.B.; Dotan, Z.A.; Diblasio, C.J.; Reuther, A.; Klein, E.A.; Kattan, M.W. Postoperative Nomogram Predicting the 10-Year Probability of Prostate Cancer Recurrence After Radical Prostatectomy. J. Clin. Oncol. 2005, 23, 7005-7012. [CrossRef]

29. Chun, F.K.-H.; Haese, A.; Ahyai, S.A.; Walz, J.; Suardi, N.; Capitanio, U.; Graefen, M.; Erbersdobler, A.; Huland, H.; Karakiewicz, P.I. Critical assessment of tools to predict clinically insignificant prostate cancer at radical prostatectomy in contemporary men. Cancer 2008, 113, 701-709. [CrossRef] [PubMed]

30. Cooperberg, M.R.; Hilton, J.F.; Carroll, P.R. The CAPRA-S score. Cancer 2011, 117, 5039-5046. [CrossRef]

31. Remmers, S.; Verbeek, J.F.M.; Nieboer, D.; Van Der Kwast, T.; Roobol-Bouts, M. Predicting biochemical recurrence and prostate cancer-specific mortality after radical prostatectomy: Comparison of six prediction models in a cohort of patients with screening- and clinically detected prostate cancer. BJU Int. 2019, 124, 635-642. [CrossRef]

32. Steyerberg, E.W.; Roobol, M.; Kattan, M.; Van Der Kwast, T.; De Koning, H.; Schröder, F. Prediction of Indolent Prostate Cancer: Validation and Updating of a Prognostic Nomogram. J. Urol. 2007, 177, 107-112. [CrossRef]

33. Gandaglia, G.; Ploussard, G.; Isbarn, H.; Suardi, N.; De Visschere, P.J.; Fütterer, J.J.; Ghadjar, P.; Massard, C.; Ost, P.; Sooriakumaran, P.; et al. What is the optimal definition of misclassification in patients with very low-risk prostate cancer eligible for active surveillance? Results from a multi-institutional series. Urol. Oncol. Semin. Orig. Investig. 2015, 33, 164.e1-164.e9. [CrossRef] [PubMed]

34. Ploussard, G.; Epstein, J.I.; Montironi, R.; Carroll, P.R.; Wirth, M.; Grimm, M.-O.; Bjartell, A.S.; Montorsi, F.; Freedland, S.J.; Erbersdobler, A.; et al. The Contemporary Concept of Significant Versus Insignificant Prostate Cancer. Eur. Urol. 2011, 60, 291-303. [CrossRef] [PubMed]

35. Hughes, C.; Murphy, A.; Martin, C.M.; Sheils, O.; O'Leary, J.J. Molecular pathology of prostate cancer. J. Clin. Pathol. 2005, 58, 673-684. [CrossRef] [PubMed]

36. Kristiansen, G. Markers of clinical utility in the differential diagnosis and prognosis of prostate cancer. Mod. Pathol. 2018, 31, 143-155. [CrossRef]

37. Clinton, T.N.; Bagrodia, A.; Lotan, Y.; Margulis, V.; Raj, G.V.; Woldu, S.L. Tissue-based biomarkers in prostate cancer. Expert Rev. Precis. Med. Drug Dev. 2017, 2, 249-260. [CrossRef]

38. Fraser, M.; Berlin, A.; Bristow, R.G.; Van Der Kwast, T. Genomic, pathological, and clinical heterogeneity as drivers of personalized medicine in prostate cancer. Urol. Oncol. Semin. Orig. Investig. 2015, 33, 85-94. [CrossRef]

39. He, W.; Bishop, K.S. The potential use of cell-free-circulating-tumor DNA as a biomarker for prostate cancer. Expert Rev. Mol. Diagn. 2016, 16, 839-852. [CrossRef] [PubMed]

40. Hendriks, R.J.; Van Oort, I.M.; Schalken, J.A. Blood-based and urinary prostate cancer biomarkers: A review and comparison of novel biomarkers for detection and treatment decisions. Prostate Cancer Prostatic Dis. 2016, 20, 12-19. [CrossRef] [PubMed]

41. Cuzick, J.; Swanson, G.P.; Fisher, G.; Brothman, A.R.; Berney, D.M.; Reid, J.E.; Mesher, D.; Speights, V.; Stankiewicz, E.; Foster, C.S.; et al. Prognostic value of an RNA expression signature derived from cell cycle proliferation genes in patients with prostate cancer: A retrospective study. Lancet Oncol. 2011, 12, 245-255. [CrossRef]

42. Klein, E.A.; Cooperberg, M.R.; Magi-Galluzzi, C.; Simko, J.P.; Falzarano, S.M.; Maddala, T.; Chan, J.M.; Li, J.; Cowan, J.E.; Tsiatis, A.C.; et al. A 17-gene Assay to Predict Prostate Cancer Aggressiveness in the Context of Gleason Grade Heterogeneity, Tumor Multifocality, and Biopsy Undersampling. Eur. Urol. 2014, 66, 550-560. [CrossRef]

43. Erho, N.; Crisan, A.; Vergara, I.A.; Mitra, A.P.; Ghadessi, M.; Buerki, C.; Bergstralh, E.J.; Kollmeyer, T.; Fink, S.; Haddad, Z.; et al. Discovery and Validation of a Prostate Cancer Genomic Classifier that Predicts Early Metastasis Following Radical Prostatectomy. PLoS ONE 2013, 8, e66855. [CrossRef] 
44. Chao, C.R.; Chi, M.; Preciado, M.; Black, M.H. Methylation markers for prostate cancer prognosis: A systematic review. Cancer Causes Control 2013, 24, 1615-1641. [CrossRef] [PubMed]

45. Strand, S.H.; Orntoft, T.F.; Sorensen, K.D. Prognostic DNA Methylation Markers for Prostate Cancer. Int. J. Mol. Sci. 2014, 15, 16544-16576. [CrossRef]

46. Chiam, K.; Ricciardelli, C.; Bianco-Miotto, T. Epigenetic biomarkers in prostate cancer: Current and future uses. Cancer Lett. 2014, 342, 248-256. [CrossRef] [PubMed]

47. Chan, M.F.; Liang, G.; Jones, P.A. Relationship between Transcription and DNA Methylation. Future HIV-1 Therapeutics 2000, 249, 75-86. [CrossRef]

48. Egger, G.; Liang, G.; Aparicio, A.; Jones, P.A. Epigenetics in human disease and prospects for epigenetic therapy. Nat. Cell Biol. 2004, 429, 457-463. [CrossRef] [PubMed]

49. Baylin, S.B.; Esteller, M.; Rountree, M.R.; Bachman, K.E.; Schuebel, K.; Herman, J.G. Aberrant patterns of DNA methylation, chromatin formation and gene expression in cancer. Hum. Mol. Genet. 2001, 10, 687-692. [CrossRef] [PubMed]

50. Majumdar, S.; Buckles, E.; Estrada, J.; Koochekpour, S. Aberrant DNA Methylation and Prostate Cancer. Curr. Genom. 2011, 12, 486-505. [CrossRef] [PubMed]

51. Aryee, M.J.; Liu, W.; Engelmann, J.C.; Nuhn, P.; Gurel, M.; Haffner, M.C.; Esopi, D.; Irizarry, R.A.; Getzenberg, R.H.; Nelson, W.G.; et al. DNA Methylation Alterations Exhibit Intraindividual Stability and Interindividual Heterogeneity in Prostate Cancer Metastases. Sci. Transl. Med. 2013, 5, 169ra10. [CrossRef]

52. Chan, T.A.; Glöckner, S.; Yi, J.M.; Chen, W.; Van Neste, L.; Cope, L.; Herman, J.G.; Velculescu, V.E.; Schuebel, K.E.; Ahuja, N.; et al. Convergence of Mutation and Epigenetic Alterations Identifies Common Genes in Cancer That Predict for Poor Prognosis. PLoS Med. 2008, 5, e114. [CrossRef]

53. Paziewska, A.; Dabrowska, M.; Goryca, K.; Antoniewicz, A.; Dobruch, J.; Mikula, M.; Jarosz, D.; Zapala, L.; Borówka, A.; Ostrowski, J. DNA methylation status is more reliable than gene expression at detecting cancer in prostate biopsy. Br. J. Cancer 2014, 111, 781-789. [CrossRef]

54. Issa, J.-P. DNA Methylation as a Clinical Marker in Oncology. J. Clin. Oncol. 2012, 30, 2566-2568. [CrossRef] [PubMed]

55. Bock, C.; Halbritter, F.; Carmona, F.J.; Tierling, S.; Datlinger, P.; Assenov, Y.; Berdasco, M.; Bergmann, A.K.; Booher, K.; Busato, F.; et al. Quantitative comparison of DNA methylation assays for biomarker development and clinical applications. Nat. Biotechnol. 2016, 34, 726-737. [CrossRef]

56. Stewart, G.S.; Van Neste, L.; Delvenne, P.; Delrée, P.; Delga, A.; McNeill, S.A.; O’Donnell, M.; Clark, J.; Van Criekinge, W.; Bigley, J.; et al. Clinical Utility of an Epigenetic Assay to Detect Occult Prostate Cancer in Histopathologically Negative Biopsies: Results of the MATLOC Study. J. Urol. 2013, 189, 1110-1116. [CrossRef]

57. Ellinger, J.; Müller, S.C.; Stadler, T.C.; Jung, A.; Von Ruecker, A.; Bastian, P.J. The role of cell-free circulating DNA in the diagnosis and prognosis of prostate cancer. Urol. Oncol. Semin. Orig. Investig. 2011, 29, 124-129. [CrossRef]

58. Rouprêt, M.; Hupertan, V.; Catto, J.W.; Yates, D.R.; Rehman, I.; Proctor, L.M.; Phillips, J.; Meuth, M.; Cussenot, O.; Hamdy, F.C. Promoter hypermethylation in circulating blood cells identifies prostate cancer progression. Int. J. Cancer 2007, 122, 952-956. [CrossRef]

59. Payne, S.R.; Serth, J.; Schostak, M.; Kamradt, J.; Strauss, A.; Thelen, P.; Model, F.; Day, J.K.; Liebenberg, V.; Morotti, A.; et al. DNA methylation biomarkers of prostate cancer: Confirmation of candidates and evidence urine is the most sensitive body fluid for non-invasive detection. Prostate 2009, 69, 1257-1269. [CrossRef]

60. Okegawa, T.; Nutahara, K.; Higashihara, E. Association of circulating tumor cells with tumor-related methylated DNA in patients with hormone-refractory prostate cancer. Int. J. Urol. 2010, 17, 466-475. [CrossRef]

61. Herman, J.G.; Graff, J.R.; Myohanen, S.; Nelkin, B.D.; Baylin, S.B. Methylation-specific PCR: A novel PCR assay for methylation status of CpG islands. Proc. Natl. Acad. Sci. USA 1996, 93, 9821-9826. [CrossRef]

62. Eads, C.A.; Danenberg, K.D.; Kawakami, K.; Saltz, L.B.; Blake, C.; Shibata, D.; Danenberg, P.V.; Laird, P.W. MethyLight: A high-throughput assay to measure DNA methylation. Nucleic Acids Res. 2000, 28, 32e-00. [CrossRef] [PubMed]

63. Tost, J.; Gut, I.; Sharon, M. Analysis of Gene-Specific DNA Methylation Patterns by Pyrosequencing ${ }^{\circledR}$ Technology. Pyrosequencing Protoc. 2007, 373, 89-102. [CrossRef] 
64. Tost, J.; Gut, I.G. DNA methylation analysis by pyrosequencing. Nat. Protoc. 2007, 2, 2265-2275. [CrossRef] [PubMed]

65. Ehrich, M.; Nelson, M.R.; Stanssens, P.; Zabeau, M.; Liloglou, T.; Xinarianos, G.; Cantor, C.R.; Field, J.K.; Boom, D.V.D. Quantitative high-throughput analysis of DNA methylation patterns by base-specific cleavage and mass spectrometry. Proc. Natl. Acad. Sci. USA 2005, 102, 15785-15790. [CrossRef] [PubMed]

66. Perkins, G.; Lu, H.; Garlan, F.; Taly, V. Droplet-Based Digital PCR. Int. Rev. Cytol. 2017, 79, 43-91. [CrossRef]

67. Brena, R.M.; Auer, H.; Kornacker, K.; Plass, C. Quantification of DNA methylation in electrofluidics chips (Bio-COBRA). Nat. Protoc. 2006, 1, 52-58. [CrossRef]

68. Wong, E.M.; Dobrovic, A. Assessing Gene-Specific Methylation Using HRM-Based Analysis. Recent Results Cancer Res. 2010, 687, 207-217. [CrossRef]

69. Rand, K.N.; Ho, T.; Qu, W.; Mitchell, S.M.; White, R.; Clark, S.J.; Molloy, P.L. Headloop suppression PCR and its application to selective amplification of methylated DNA sequences. Nucleic Acids Res. 2005, 33, e127. [CrossRef]

70. Devaney, J.; Stirzaker, C.; Qu, W.; Song, J.Z.; Statham, A.L.; Patterson, K.I.; Horvath, L.G.; Tabor, B.; Coolen, M.W.; Hulf, T.; et al. Epigenetic Deregulation Across Chromosome 2q14.2 Differentiates Normal from Prostate Cancer and Provides a Regional Panel of Novel DNA Methylation Cancer Biomarkers. Cancer Epidemiol. Biomark. Prev. 2010, 20, 148-159. [CrossRef]

71. Montavon, C.; Gloss, B.S.; Warton, K.; Barton, C.A.; Statham, A.L.; Scurry, J.P.; Tabor, B.; Nguyen, T.V.; Qu, W.; Samimi, G.; et al. Prognostic and diagnostic significance of DNA methylation patterns in high grade serous ovarian cancer. Gynecol. Oncol. 2012, 124, 582-588. [CrossRef]

72. Xie, W.; Regan, M.M.; Buyse, M.; Halabi, S.; Kantoff, P.W.; Sartor, O.; Soule, H.; Clarke, N.W.; Collette, L.; Dignam, J.J.; et al. Metastasis-Free Survival Is a Strong Surrogate of Overall Survival in Localized Prostate Cancer. J. Clin. Oncol. 2017, 35, 3097-3104. [CrossRef]

73. Zhang, A.; Chiam, K.; Haupt, Y.; Fox, S.; Birch, S.; Tilley, W.; Butler, L.M.; Knudsen, K.; Comstock, C.; Rasiah, K.; et al. An analysis of a multiple biomarker panel to better predict prostate cancer metastasis after radical prostatectomy. Int. J. Cancer 2018, 144, 1151-1159. [CrossRef]

74. Yegnasubramanian, S.; Kowalski, J.; Gonzalgo, M.L.; Zahurak, M.; Piantadosi, S.; Walsh, P.C.; Bova, G.S.; De Marzo, A.M.; Isaacs, W.B.; Nelson, W.G. Hypermethylation of CpG islands in primary and metastatic human prostate cancer. Cancer Res. 2004, 64, 1975-1986. [CrossRef] [PubMed]

75. Rosenbaum, E.; Hoque, M.O.; Cohen, Y.; Zahurak, M.; Eisenberger, M.A.; Epstein, J.I.; Partin, A.W.; Sidransky, D. Promoter Hypermethylation as an Independent Prognostic Factor for Relapse in Patients with Prostate Cancer Following Radical Prostatectomy. Clin. Cancer Res. 2005, 11, 8321-8325. [CrossRef]

76. Woodson, K.; O’Reilly, K.J.; Ward, D.E.; Walter, J.; Hanson, J.; Walk, E.L.; Tangrea, J.A. CD44 and PTGS2 Methylation are Independent Prognostic Markers for Biochemical Recurrence Among Prostate Cancer Patients with Clinically Localized Disease. Epigenetics 2006, 1, 183-186. [CrossRef] [PubMed]

77. Henrique, R.; Ribeiro, F.R.; Fonseca, D.; Hoque, M.O.; Carvalho, A.L.; Costa, V.L.; Pinto, M.; Oliveira, J.; Teixeira, M.R.; Sidransky, D.; et al. High Promoter Methylation Levels of APC Predict Poor Prognosis in Sextant Biopsies from Prostate Cancer Patients. Clin. Cancer Res. 2007, 13, 6122-6129. [CrossRef]

78. Ellinger, J.; Bastian, P.J.; Jurgan, T.; Biermann, K.; Kahl, P.; Heukamp, L.; Wernert, N.; Müller, S.; Von Ruecker, A. CpG Island Hypermethylation at Multiple Gene Sites in Diagnosis and Prognosis of Prostate Cancer. Urol. 2008, 71, 161-167. [CrossRef] [PubMed]

79. Alumkal, J.J.; Zhang, Z.; Humphreys, E.B.; Bennett, C.; Mangold, L.A.; Carducci, M.A.; Partin, A.W.; Garrett-Mayer, E.; DeMarzo, A.M.; Herman, J.G. Effect of DNA Methylation on Identification of Aggressive Prostate Cancer. Urology 2008, 72, 1234-1239. [CrossRef] [PubMed]

80. Weiss, G.; Cottrell, S.; Distler, J.; Schatz, P.; Kristiansen, G.; Ittmann, M.; Haefliger, C.; Lesche, R.; Hartmann, A.; Corman, J.; et al. DNA Methylation of the PITX2 Gene Promoter Region is a Strong Independent Prognostic Marker of Biochemical Recurrence in Patients With Prostate Cancer After Radical Prostatectomy. J. Urol. 2009, 181, 1678-1685. [CrossRef] [PubMed]

81. Vanaja, D.K.; Ehrich, M.; Boom, D.V.D.; Cheville, J.C.; Karnes, R.J.; Tindall, D.J.; Cantor, C.R.; Young, C.Y. Hypermethylation of Genes for Diagnosis and Risk Stratification of Prostate Cancer. Cancer Investig. 2009, 27, 549-560. [CrossRef] 
82. Richiardi, L.; Fiano, V.; Vizzini, L.; De Marco, L.; Delsedime, L.; Akre, O.; Tos, A.G.; Merletti, F. Promoter Methylation in APC, RUNX3, and GSTP1 and Mortality in Prostate Cancer Patients. J. Clin. Oncol. 2009, 27, 3161-3168. [CrossRef]

83. Bañez, L.L.; Sun, L.; Van Leenders, G.J.; Wheeler, T.M.; Bangma, C.H.; Freedland, S.J.; Ittmann, M.M.; Lark, A.L.; Madden, J.F.; Hartman, A.; et al. Multicenter Clinical Validation of PITX2 Methylation as a Prostate Specific Antigen Recurrence Predictor in Patients With Post-Radical Prostatectomy Prostate Cancer. J. Urol. 2010, 184, 149-156. [CrossRef]

84. Vasiljevic, N.; Wu, K.; Brentnall, A.R.; Kim, D.C.; Thorat, M.A.; Kudahetti, S.C.; Mao, X.; Xue, L.; Yu, Y.; Shaw, G.L.; et al. Absolute quantitation of DNA methylation of 28 candidate genes in prostate cancer using pyrosequencing. Dis. Markers 2011, 30, 151-161. [CrossRef] [PubMed]

85. Rosenbaum, E.; Begum, S.; Brait, M.; Zahurak, M.; Maldonado, L.; Mangold, L.A.; Eisenberger, M.A.; Epstein, J.I.; Partin, A.W.; Sidransky, D.; et al. AIM1 promoter hypermethylation as a predictor of decreased risk of recurrence following radical prostatectomy. Prostate 2011, 72, 1133-1139. [CrossRef] [PubMed]

86. Vasiljević, N.; Ahmad, A.S.; Beesley, C.; Thorat, M.A.; Fisher, G.; Berney, D.M.; Moller, H.; Yu, Y.; Lu, Y.-J.; Cuzick, J.; et al. Association between DNA methylation of HSPB1 and death in low Gleason score prostate cancer. Prostate Cancer Prostatic Dis. 2012, 16, 35-40. [CrossRef]

87. Dietrich, D.; Hasinger, O.; Bañez, L.L.; Sun, L.; Van Leenders, G.J.; Wheeler, T.M.; Bangma, C.H.; Wernert, N.; Perner, S.; Freedland, S.J.; et al. Development and Clinical Validation of a Real-Time PCR Assay for PITX2 DNA Methylation to Predict Prostate-Specific Antigen Recurrence in Prostate Cancer Patients Following Radical Prostatectomy. J. Mol. Diagn. 2013, 15, 270-279. [CrossRef] [PubMed]

88. Richiardi, L.; Fiano, V.; Grasso, C.; Zugna, D.; Delsedime, L.; Gillio-Tos, A.; Merletti, F. Methylation of APC and GSTP1 in Non-Neoplastic Tissue Adjacent to Prostate Tumour and Mortality from Prostate Cancer. PLoS ONE 2013, 8, e68162. [CrossRef]

89. Moritz, R.; Ellinger, J.; Nuhn, P.; Haese, A.; Müller, S.; Graefen, M.; Schlomm, T.; Bastian, P.-D.D.M.P.J. DNA hypermethylation as a predictor of PSA recurrence in patients with low- and intermediate-grade prostate cancer. Anticancer. Res. 2013, 33, 5249-5254.

90. Vasiljević, N.; Ahmad, A.S.; Thorat, M.A.; Fisher, G.; Berney, D.M.; Moller, H.; Foster, C.S.; Cuzick, J.; Lorincz, A.T. DNA methylation gene-based models indicating independent poor outcome in prostate cancer. BMC Cancer 2014, 14, 655. [CrossRef]

91. Vasiljević, N.; Ahmad, A.S.; Carter, P.D.; Fisher, G.; Berney, D.M.; Foster, C.S.; Cuzick, J.; Lorincz, A.T. DNA methylation ofPITX2predicts poor survival in men with prostate cancer. Biomark. Med. 2014, 8, 1143-1150. [CrossRef]

92. Maldonado, L.; Brait, M.; Loyo, M.; Sullenberger, L.; Wang, K.; Peskoe, S.B.; Rosenbaum, E.; Howard, R.; Toubaji, A.; Albadine, R.; et al. GSTP1Promoter Methylation is Associated with Recurrence in Early Stage Prostate Cancer. J. Urol. 2014, 192, 1542-1548. [CrossRef]

93. Daniunaite, K.; Jarmalaite, S.; Kalinauskaite, N.; Petroska, D.; Laurinavicius, A.; Lazutka, J.R.; Jankevicius, F. Prognostic Value of RASSF1 Promoter Methylation in Prostate Cancer. J. Urol. 2014, 192, 1849-1855. [CrossRef]

94. Litovkin, K.; Van Eynde, A.; Joniau, S.; Lerut, E.; Laenen, A.; Gevaert, T.; Gevaert, O.; Spahn, M.; Kneitz, B.; Gramme, P.; et al. DNA Methylation-Guided Prediction of Clinical Failure in High-Risk Prostate Cancer. PLoS ONE 2015, 10, e0130651. [CrossRef] [PubMed]

95. Carozzi, F.M.; Tamburrino, L.; Bisanzi, S.; Marchiani, S.; Paglierani, M.; Di Lollo, S.; Crocetti, E.; Buzzoni, C.; Burroni, E.; Greco, L.; et al. Are biomarkers evaluated in biopsy specimens predictive of prostate cancer aggressiveness? J. Cancer Res. Clin. Oncol. 2015, 142, 201-212. [CrossRef] [PubMed]

96. Rybicki, B.A.; Rundle, A.; Kryvenko, O.N.; Mitrache, N.; Do, K.C.; Jankowski, M.; Chitale, D.; Trudeau, S.; Belinsky, S.A.; Tang, D. Methylation in benign prostate and risk of disease progression in men subsequently diagnosed with prostate cancer. Int. J. Cancer 2016, 138, 2884-2893. [CrossRef]

97. Holmes, E.E.; Goltz, D.; Sailer, V.; Jung, M.; Meller, S.; Uhl, B.; Dietrich, J.; Röhler, M.; Ellinger, J.; Kristiansen, G.; et al. PITX3 promoter methylation is a prognostic biomarker for biochemical recurrence-free survival in prostate cancer patients after radical prostatectomy. Clin. Epigenetics 2016, 8, 104. [CrossRef] [PubMed]

98. Ahmad, A.S.; Vasiljević, N.; Carter, P.; Berney, D.M.; Moller, H.; Foster, C.S.; Cuzick, J.; Lorincz, A.T. A novel DNA methylation score accurately predicts death from prostate cancer in men with low to intermediate clinical risk factors. Oncotarget 2016, 7, 71833-71840. [CrossRef] [PubMed] 
99. Uhl, B.; Gevensleben, H.; Tolkach, Y.; Sailer, V.; Majores, M.; Jung, M.; Meller, S.; Stein, J.; Ellinger, J.; Dietrich, D.; et al. PITX2 DNA Methylation as Biomarker for Individualized Risk Assessment of Prostate Cancer in Core Biopsies. J. Mol. Diagn. 2017, 19, 107-114. [CrossRef] [PubMed]

100. Van Neste, L.; Herman, J.G.; Otto, G.; Bigley, J.W.; Epstein, J.I.; Van Criekinge, W. The Epigenetic promise for prostate cancer diagnosis. Prostate 2011, 72, 1248-1261. [CrossRef] [PubMed]

101. Tew, K.D.; Manevich, Y.; Grek, C.; Xiong, Y.; Uys, J.; Townsend, D.M. The role of glutathione S-transferase P in signaling pathways and S-glutathionylation in cancer. Free. Radic. Biol. Med. 2011, 51, 299-313. [CrossRef]

102. Henrique, R.; Jerónimo, C. Molecular Detection of Prostate Cancer: A Role for GSTP1 Hypermethylation. Eur. Urol. 2004, 46, 660-669. [CrossRef]

103. Aoki, K.; Taketo, M.M. Adenomatous polyposis coli (APC): A multi-functional tumor suppressor gene. J. Cell Sci. 2007, 120, 3327-3335. [CrossRef]

104. Chen, Y.; Li, J.; Yu, X.; Li, S.; Zhang, X.; Mo, Z.; Hu, Y. APC gene hypermethylation and prostate cancer: A systematic review and meta-analysis. Eur. J. Hum. Genet. 2013, 21, 929-935. [CrossRef] [PubMed]

105. Moison, C.; Assemat, F.; Daunay, A.; Tost, J.; Guieysse-Peugeot, A.-L.; Arimondo, P.B. Synergistic chromatin repression of the tumor suppressor gene RARB in human prostate cancers. Epigenetics 2014, 9, 477-482. [CrossRef] [PubMed]

106. Kioussi, C.; Briata, P.; Baek, S.H.; Rose, D.W.; Hamblet, N.S.; Herman, T.; Ohgi, K.A.; Lin, C.; Gleiberman, A.; Wang, J.; et al. Identification of a Wnt/Dvl/ $\beta$-Catenin $\rightarrow$ Pitx2 Pathway Mediating Cell-Type-Specific Proliferation during Development. Cell 2002, 111, 673-685. [CrossRef]

107. Harbeck, N.; Nimmrich, I.; Hartmann, A.; Ross, J.S.; Cufer, T.; Grützmann, R.; Kristiansen, G.; Paradiso, A.; Hartmann, O.; Margossian, A.; et al. Multicenter Study Using Paraffin-Embedded Tumor Tissue Testing PITX2 DNA Methylation As a Marker for Outcome Prediction in Tamoxifen-Treated, Node-Negative Breast Cancer Patients. J. Clin. Oncol. 2008, 26, 5036-5042. [CrossRef] [PubMed]

108. Goltz, D.; Holmes, E.E.; Gevensleben, H.; Sailer, V.; Dietrich, J.; Jung, M.; Röhler, M.; Meller, S.; Ellinger, J.; Kristiansen, G.; et al. CXCL12 promoter methylation and PD-L1 expression as prognostic biomarkers in prostate cancer patients. Oncotarget 2016, 7, 53309-53320. [CrossRef]

109. Gevensleben, H.; Holmes, E.E.; Goltz, D.; Dietrich, J.; Sailer, V.; Ellinger, J.; Dietrich, D.; Kristiansen, G. PD-L1 promoter methylation is a prognostic biomarker for biochemical recurrence-free survival in prostate cancer patients following radical prostatectomy. Oncotarget 2016, 7, 79943-79955. [CrossRef]

110. Meller, S.; Zipfel, L.; Gevensleben, H.; Dietrich, J.; Ellinger, J.; Majores, M.; Stein, J.; Sailer, V.; Jung, M.; Kristiansen, G.; et al. CDO1 promoter methylation is associated with gene silencing and is a prognostic biomarker for biochemical recurrence-free survival in prostate cancer patients. Epigenetics 2016, 11, 871-880. [CrossRef]

111. Nørgaard, M.; Haldrup, C.; Storebjerg, T.M.; Vestergaard, E.M.; Wild, P.J.; Høyer, S.; Borre, M.; Ørntoft, T.; Sørensen, K.D. Comprehensive Evaluation of TFF3 Promoter Hypomethylation and Molecular Biomarker Potential for Prostate Cancer Diagnosis and Prognosis. Int. J. Mol. Sci. 2017, 18, 2017. [CrossRef]

112. Haldrup, C.; Pedersen, A.L.; Ogaard, N.; Strand, S.H.; Hoyer, S.; Borre, M.; Orntoft, T.F.; Sorensen, K.D. Biomarker potential of ST6G ALNAC3 and ZNF660 promoter hypermethylation in prostate cancer tissue and liquid biopsies. Mol. Oncol. 2018, 12, 545-560. [CrossRef]

113. Haldrup, C.; Mundbjerg, K.; Vestergaard, E.M.; Lamy, P.; Wild, P.; Schulz, W.A.; Arsov, C.; Visakorpi, T.; Borre, M.; Høyer, S.; et al. DNA Methylation Signatures for Prediction of Biochemical Recurrence After Radical Prostatectomy of Clinically Localized Prostate Cancer. J. Clin. Oncol. 2013, 31, 3250-3258. [CrossRef]

114. Torres-Ferreira, J.; Ramalho-Carvalho, J.; Gomez, A.; Menezes, F.D.; Freitas, R.; Oliveira, J.; Antunes, L.; Bento, M.J.; Esteller, M.; Henrique, R.; et al. MiR1-93b promoter methylation accurately detects prostate cancer in urine sediments and miR3-4b/c or miR1-29-2 promoter methylation define subsets of clinically aggressive tumors. Mol. Cancer 2017, 16, 26. [CrossRef] [PubMed]

115. Daniunaite, K.; Dubikaityte, M.; Gibas, P.; Bakavicius, A.; Lazutka, J.R.; Ulys, A.; Jankevicius, F.; Jarmalaite, S. Clinical significance of miRNA host gene promoter methylation in prostate cancer. Hum. Mol. Genet. 2017, 26, 2451-2461. [CrossRef] [PubMed]

116. Strand, S.H.; świtnicki, M.; Moller, M.; Haldrup, C.; Storebjerg, T.M.; Hedegaard, J.; Nordentoft, I.; Hoyer, S.; Borre, M.; Pedersen, J.S.; et al. RHCG and TCAF1 promoter hypermethylation predicts biochemical recurrence in prostate cancer patients treated by radical prostatectomy. Oncotarget 2016, 8, 5774-5788. [CrossRef] 
117. Bjerre, M.T.; Strand, S.H.; Nørgaard, M.; Kristensen, H.; Rasmussen, A.K.; Mortensen, M.M.; Fredsøe, J.; Mouritzen, P.; Ulhøi, B.; Ørntoft, T.; et al. Aberrant DOCK2, GRASP, HIF3A and PKFP Hypermethylation has Potential as a Prognostic Biomarker for Prostate Cancer. Int. J. Mol. Sci. 2019, 20, 1173. [CrossRef]

118. Li, X.; Zhang, W.; Song, J.; Zhang, X.; Ran, L.; He, Y. SLCO4C1 promoter methylation is a potential biomarker for prognosis associated with biochemical recurrence-free survival after radical prostatectomy. Clin. Epigenetics 2019, 11,99. [CrossRef]

119. Nørgaard, M.; Haldrup, C.; Bjerre, M.T.; Høyer, S.; Ulhøi, B.P.; Borre, M.; Sorensen, K.D. Epigenetic silencing of MEIS2 in prostate cancer recurrence. Clin. Epigenetics 2019, 11, 147. [CrossRef]

120. Cottrell, S.; Jung, K.; Kristiansen, G.; Eltze, E.; Semjonow, A.; Ittmann, M.; Hartmann, A.; Stamey, T.; Haefliger, C.; Weiss, G. Discovery and Validation of 3 Novel DNA Methylation Markers of Prostate Cancer Prognosis. J. Urol. 2007, 177, 1753-1758. [CrossRef]

121. Lin, P.-C.; Giannopoulou, E.G.; Park, K.; Mosquera, J.M.; Sboner, A.; Tewari, A.K.; Garraway, L.A.; Beltran, H.; Rubin, M.A.; Elemento, O. Epigenomic Alterations in Localized and Advanced Prostate Cancer. Neoplasia 2013, 15, 373-IN5. [CrossRef]

122. Bhasin, J.M.; Lee, B.H.; Matkin, L.; Taylor, M.G.; Hu, B.; Xu, Y.; Magi-Galluzzi, C.; Klein, E.A.; Ting, A.H. Methylome-wide Sequencing Detects DNA Hypermethylation Distinguishing Indolent from Aggressive Prostate Cancer. Cell Rep. 2015, 13, 2135-2146. [CrossRef]

123. Kron, K.; Pethe, V.; Briollais, L.; Sadikovic, B.; Ozcelik, H.; Sunderji, A.; Venkateswaran, V.; Pinthus, J.; Fleshner, N.; Van Der Kwast, T.; et al. Discovery of Novel Hypermethylated Genes in Prostate Cancer Using Genomic CpG Island Microarrays. PLoS ONE 2009, 4, e4830. [CrossRef]

124. Kron, K.J.; Liu, L.; Pethe, V.V.; Demetrashvili, N.; Nesbitt, M.E.; Trachtenberg, J.; Ozcelik, H.; Fleshner, N.E.; Briollais, L.; Van Der Kwast, T.H.; et al. DNA methylation of HOXD3 as a marker of prostate cancer progression. Lab. Investig. 2010, 90, 1060-1067. [CrossRef] [PubMed]

125. Liu, L.; Kron, K.J.; Pethe, V.V.; Demetrashvili, N.; Nesbitt, M.; Trachtenberg, J.; Ozcelik, H.; Fleshner, N.E.; Briollais, L.; Van Der Kwast, T.H.; et al. Association of tissue promoter methylation levels of APC, TGF 32 , HOXD3 and RASSF1A with prostate cancer progression. Int. J. Cancer 2011, 129, 2454-2462. [CrossRef] [PubMed]

126. Jeyapala, R.; Savio, A.J.; Olkhov-Mitsel, E.; Kamdar, S.; Zhao, F.; Cuizon, C.; Liu, R.S.; Zlotta, A.; Fleshner, N.; Van Der Kwast, T.; et al. GBX2 Methylation Is a Novel Prognostic Biomarker and Improves Prediction of Biochemical Recurrence Among Patients with Prostate Cancer Negative for Intraductal Carcinoma and Cribriform Architecture. Eur. Urol. Oncol. 2019, 2, 231-238. [CrossRef] [PubMed]

127. Jeyapala, R.; Kamdar, S.; Olkhov-Mitsel, E.; Savio, A.J.; Zhao, F.; Cuizon, C.; Liu, R.S.; Zlotta, A.; Fleshner, N.; Van Der Kwast, T.; et al. An integrative DNA methylation model for improved prognostication of postsurgery recurrence and therapy in prostate cancer patients. Urol. Oncol. Semin. Orig. Investig. 2020, 38, 39.e1-39.e9. [CrossRef]

128. Savio, A.J.; Kamdar, S.; Jeyapala, R.; Olkhov-Mitsel, E.; Cuizon, C.; Finelli, A.; Zlotta, A.R.; Toi, A.; Fleshner, N.E.; Van Der Kwast, T.; et al. Methylation Markers in Prostate Biopsies Are Prognosticators for Late Biochemical Recurrence and Therapy after Surgery in Prostate Cancer Patients. J. Mol. Diagn. 2019, 22, 30-39. [CrossRef]

129. Goh, L.-K.; Liem, N.; Vijayaraghavan, A.; Chen, G.; Lim, P.L.; Tay, K.J.; Chang, M.; Low, J.S.W.; Joshi, A.; Huang, H.H.; et al. Diagnostic and Prognostic Utility of a DNA Hypermethylated Gene Signature in Prostate Cancer. PLoS ONE 2014, 9, e91666. [CrossRef]

130. Angulo, J.; López, J.I.; Dorado, J.F.; Sanchez-Chapado, M.; Colas, B.; Ropero, S. A DNA Hypermethylation Profile Independently Predicts Biochemical Recurrence Following Radical Prostatectomy. Urol. Int. 2016, 97, 16-25. [CrossRef]

131. Kobayashi, Y.; Absher, D.M.; Gulzar, Z.G.; Young, S.R.; McKenney, J.K.; Peehl, D.M.; Brooks, J.D.; Myers, R.M.; Sherlock, G. DNA methylation profiling reveals novel biomarkers and important roles for DNA methyltransferases in prostate cancer. Genome Res. 2011, 21, 1017-1027. [CrossRef]

132. Mahapatra, S.; Klee, E.W.; Young, C.Y.F.; Sun, Z.; Jimenez, R.E.; Klee, G.G.; Tindall, D.J.; Donkena, K.V. Global Methylation Profiling for Risk Prediction of Prostate Cancer. Clin. Cancer Res. 2012, 18, 2882-2895. [CrossRef]

133. Geybels, M.S.; Wright, J.L.; Bibikova, M.; Klotzle, B.; Fan, J.-B.; Zhao, S.; Feng, Z.; Ostrander, E.A.; Lin, D.; Nelson, P.S.; et al. Epigenetic signature of Gleason score and prostate cancer recurrence after radical prostatectomy. Clin. Epigenetics 2016, 8, 97. [CrossRef] 
134. Zhao, S.; Geybels, M.S.; Leonardson, A.; Rubicz, R.; Kolb, S.; Yan, Q.; Klotzle, B.; Bibikova, M.; Hurtado-Coll, A.; Troyer, D.; et al. Epigenome-Wide Tumor DNA Methylation Profiling Identifies Novel Prognostic Biomarkers of Metastatic-Lethal Progression in Men Diagnosed with Clinically Localized Prostate Cancer. Clin. Cancer Res. 2016, 23, 311-319. [CrossRef] [PubMed]

135. Zhao, S.; Leonardson, A.; Geybels, M.S.; McDaniel, A.S.; Yu, M.; Kolb, S.; Zong, H.; Carter, K.; Siddiqui, J.; Cheng, A.; et al. A five-CpG DNA methylation score to predict metastatic-lethal outcomes in men treated with radical prostatectomy for localized prostate cancer. Prostate 2018, 78, 1084-1091. [CrossRef] [PubMed]

136. Mundbjerg, K.; Chopra, S.; Alemozaffar, M.; Duymich, C.; Lakshminarasimhan, R.; Nichols, P.W.; Aron, M.; Siegmund, K.D.; Ukimura, O.; Aron, M.; et al. Identifying aggressive prostate cancer foci using a DNA methylation classifier. Genome Biol. 2017, 18, 3. [CrossRef] [PubMed]

137. Toth, R.; Schiffmann, H.; Hube-Magg, C.; Büscheck, F.; Höflmayer, D.; Weidemann, S.; Lebok, P.; Fraune, C.; Minner, S.; Schlomm, T.; et al. Random forest-based modelling to detect biomarkers for prostate cancer progression. Clin. Epigenetics 2019, 11, 148. [CrossRef]

138. Gerhauser, C.; Favero, F.; Risch, T.; Simon, R.; Feuerbach, L.; Assenov, Y.; Heckmann, D.; Sidiropoulos, N.; Waszak, S.M.; Hübschmann, D.; et al. Molecular Evolution of Early-Onset Prostate Cancer Identifies Molecular Risk Markers and Clinical Trajectories. Cancer Cell 2018, 34, 996-1011. [CrossRef]

139. Liang, G.; Gonzalgo, M.L.; Salem, C.; Jones, P.A. Identification of DNA methylation differences during tumorigenesis by methylation-sensitive arbitrarily primed polymerase chain reaction. Methods 2002, 27, 150-155. [CrossRef]

140. Toyota, M.; Issa, J.-P.J.; Mills, K.I.; Ramsahoye, B.H. Methylated CpG Island Amplification for Methylation Analysis and Cloning Differentially Methylated Sequences. DNA Methylation Protoc. 2003, 200, 101-110. [CrossRef]

141. Stott-Miller, M.; Zhao, S.; Wright, J.L.; Kolb, S.; Bibikova, M.; Klotzle, B.; Ostrander, E.A.; Fan, J.-B.; Feng, Z.; Stanford, J.L. Validation study of genes with hypermethylated promoter regions associated with prostate cancer recurrence. Cancer Epidemiol. Biomark. Prev. 2014, 23, 1331-1339. [CrossRef]

142. Altuna, A.; Garrett-Bakelman, F.E.; Kormaksson, M.; Busuttil, J.; Zhang, L.; Khrebtukova, I.; Milne, T.A.; Huang, Y.; Biswas, D.; Hess, J.L.; et al. Base-Pair Resolution DNA Methylation Sequencing Reveals Profoundly Divergent Epigenetic Landscapes in Acute Myeloid Leukemia. PLoS Genet. 2012, 8, e1002781. [CrossRef]

143. Garrett-Bakelman, F.; Sheridan, C.K.; Kacmarczyk, T.J.; Ishii, J.; Betel, R.; Alonso, A.; Mason, C.E.; Figueroa, M.E.; Melnick, A.M. Enhanced reduced representation bisulfite sequencing for assessment of DNA methylation at base pair resolution. J. Vis. Exp. 2015, 10, e52246. [CrossRef]

144. Hopkins, T.G.; Burns, P.A.; Routledge, M. DNA Methylation of GSTP1 as Biomarker in Diagnosis of Prostate Cancer. Urol. 2007, 69, 11-16. [CrossRef] [PubMed]

145. Stirzaker, C.; Taberlay, P.C.; Statham, A.L.; Clark, S.J. Mining cancer methylomes: Prospects and challenges. Trends Genet. 2014, 30, 75-84. [CrossRef] [PubMed]

146. Serre, D.; Lee, B.H.; Ting, A.H. MBD-isolated Genome Sequencing provides a high-throughput and comprehensive survey of DNA methylation in the human genome. Nucleic Acids Res. 2009, 38, 391-399. [CrossRef] [PubMed]

147. Abeshouse, A.; Ahn, J.; Akbani, R.; Ally, A.; Amin, S.; Andry, C.D.; Annala, M.; Aprikian, A.; Armenia, J.; Arora, A.; et al. The Molecular Taxonomy of Primary Prostate Cancer. Cell 2015, 163, 1011-1025. [CrossRef] [PubMed]

148. Agilent. Human CpG Island Microarray. Available online: https://www.agilent.com/en/product/methylationchip-on-chip-microarray-platform/epigenetic-specialty-microarrays/dna-methylation-microarrays/ human-cpg-island-microarray2\$-\$28444\#: \{\}:text=Human $\% 20 \mathrm{CpG} \% 20$ microarrays $\% 20$ enable $\%$ 20comprehensive,correlated $\% 20$ to $\% 20 \mathrm{key} \% 20 \mathrm{biological} \% 20$ processes.\&text=237\%2C220\%20unique $\%$ 20probes\%20in\%20or,genome\%20in\%20a\%20single\%20experiment (accessed on 11 September 2020).

149. Illumina. High-Throughput DNA Methylation Profiling with Illumina GoldenGate Technology. Available online: https:/sapac.illumina.com/content/dam/illumina-marketing/documents/products/ datasheets/datasheet_goldengate_methylation.pdf (accessed on 11 September 2020).

150. Bibikova, M.; Barnes, B.; Tsan, C.; Ho, V.; Klotzle, B.; Le, J.M.; Delano, D.; Zhang, L.; Schroth, G.P.; Gunderson, K.L.; et al. High density DNA methylation array with single CpG site resolution. Genomics 2011, 98, 288-295. [CrossRef] [PubMed] 
151. Pidsley, R.; Zotenko, E.; Peters, T.J.; Lawrence, M.G.; Risbridger, G.P.; Molloy, P.; Van Djik, S.; Muhlhausler, B.S.; Stirzaker, C.; Clark, S.J. Critical evaluation of the Illumina MethylationEPIC BeadChip microarray for whole-genome DNA methylation profiling. Genome Biol. 2016, 17, 208. [CrossRef]

152. Lister, R.; Pelizzola, M.; Dowen, R.H.; Hawkins, R.D.; Hon, G.; Tonti-Filippini, J.; Nery, J.R.; Lee, L.; Ye, Z.; Ngo, Q.-M.; et al. Human DNA methylomes at base resolution show widespread epigenomic differences. Nat. Cell Biol. 2009, 462, 315-322. [CrossRef]

153. Shen, S.Y.; Singhania, R.; Fehringer, G.; Chakravarthy, A.; Roehrl, M.H.A.; Chadwick, D.; Zuzarte, P.C.; Borgida, A.; Wang, T.T.; Li, T.; et al. Sensitive tumour detection and classification using plasma cell-free DNA methylomes. Nat. Cell Biol. 2018, 563, 579-583. [CrossRef]

154. Lee, T.-H.; Montalvo, L.; Chrebtow, V.; Busch, M.P. Quantitation of genomic DNA in plasma and serum samples: Higher concentrations of genomic DNA found in serum than in plasma. Transfusion 2001, 41, 276-282. [CrossRef]

155. Schwarzenbach, H.; Hoon, D.S.B.; Pantel, K. Cell-free nucleic acids as biomarkers in cancer patients. Nat. Rev. Cancer 2011, 11, 426-437. [CrossRef]

156. Wu, T.; Giovannucci, E.; Welge, J.; Mallick, P.; Tang, W.-Y.; Ho, S.-M. Measurement of GSTP1 promoter methylation in body fluids may complement PSA screening: A meta-analysis. Br. J. Cancer 2011, 105, 65-73. [CrossRef]

157. Cairns, P.; Esteller, M.; Herman, J.G.; Schoenberg, M.; Jeronimo, C.; Sanchez-Cespedes, M.; Chow, N.H.; Grasso, M.; Wu, L.; Westra, W.B.; et al. Molecular detection of prostate cancer in urine by GSTP1 hypermethylation. Clin. Cancer Res. 2001, 7, 2727-2730.

158. Baden, J.; Adams, S.; Astacio, T.; Jones, J.; Markiewicz, J.; Painter, J.; Trust, C.; Wang, Y.; Green, G. Predicting Prostate Biopsy Result in Men With Prostate Specific Antigen 2.0 to $10.0 \mathrm{ng} / \mathrm{mL}$ Using an Investigational Prostate Cancer Methylation Assay. J. Urol. 2011, 186, 2101-2106. [CrossRef] [PubMed]

159. O’Reilly, E.; Tuzova, A.V.; Walsh, A.L.; Russell, N.M.; O’Brien, O.; Kelly, S.; Ni Dhomhnallain, O.; DeBarra, L.; Dale, C.M.; Brugman, R.; et al. epiCaPture: A Urine DNA Methylation Test for Early Detection of Aggressive Prostate Cancer. JCO Precis. Oncol. 2019, 2019, 1-18. [CrossRef]

160. Cooperberg, M.R.; Pasta, D.J.; Elkin, E.P.; Litwin, M.S.; Latini, D.M.; Du Chane, J.; Carroll, P.R. The University of California, San Francisco Cancer of the Prostate Risk Assessment Score: A Straightforward and Reliable Preoperative Predictor of Disease Recurrence after Radical Prostatectomy. J. Urol. 2005, 173, 1938-1942. [CrossRef]

161. Zhao, F.; Jeyapala, R.; Olkhov-Mitsel, E.; Vesprini, D.; Fleshner, N.E.; Bapat, B. Re: Urinary DNA Methylation Biomarkers for Noninvasive Prediction of Aggressive Disease in Patients with Prostate Cancer on Active Surveillance. J. Urol. 2018, 199, 1354-1355. [CrossRef]

162. Moreira-Barbosa, C.; Barros-Silva, D.; Costa-Pinheiro, P.; Torres-Ferreira, J.; Constâncio, V.; Freitas, R.; Oliveira, J.; Antunes, L.; Henrique, R.; Jerónimo, C. Comparing diagnostic and prognostic performance of two-gene promoter methylation panels in tissue biopsies and urines of prostate cancer patients. Clin. Epigenetics 2018, 10, 132. [CrossRef] [PubMed]

163. Bastian, P.J.; Palapattu, G.S.; Lin, X.; Yegnasubramanian, S.; Mangold, L.A.; Trock, B.; Eisenberger, M.A.; Partin, A.W.; Nelson, W.G. Preoperative Serum DNA GSTP1 CpG Island Hypermethylation and the Risk of Early Prostate-Specific Antigen Recurrence Following Radical Prostatectomy. Clin. Cancer Res. 2005, 11, 4037-4043. [CrossRef]

164. Mahon, K.L.; Qu, W.; Devaney, J.; Paul, C.; Castillo, L.; Wykes, R.J.; Chatfield, M.D.; Boyer, M.J.; Stockler, M.R.; Marx, G.; et al. Methylated Glutathione S-transferase 1 (mGSTP1) is a potential plasma free DNA epigenetic marker of prognosis and response to chemotherapy in castrate-resistant prostate cancer. Br. J. Cancer 2014, 111, 1802-1809. [CrossRef]

165. Reibenwein, J.; Pils, D.; Horak, P.; Tomicek, B.; Goldner, G.; Worel, N.; Elandt, K.; Krainer, M. Promoter hypermethylation of GSTP1, AR, and 14-3-3 $\sigma$ in serum of prostate cancer patients and its clinical relevance. Prostate 2007, 67, 427-432. [CrossRef]

166. Hendriks, R.J.; Dijkstra, S.; Smit, F.P.; Vandersmissen, J.; Van De Voorde, H.; Mulders, P.F.A.; Van Oort, I.M.; Van Criekinge, W.; Schalken, J. Epigenetic markers in circulating cell-free DNA as prognostic markers for survival of castration-resistant prostate cancer patients. Prostate 2018, 78, 336-342. [CrossRef] [PubMed] 
167. Sunami, E.; Shinozaki, M.; Higano, C.S.; Wollman, R.; Dorff, T.B.; Tucker, S.J.; Martinez, S.R.; Singer, F.R.; Hoon, D.S. Multimarker Circulating DNA Assay for Assessing Blood of Prostate Cancer Patients. Clin. Chem. 2009, 55, 559-567. [CrossRef]

168. Horning, A.M.; Awe, J.A.; Wang, C.-M.; Liu, J.; Lai, Z.; Wang, V.Y.; Jadhav, R.R.; Louie, A.D.; Lin, C.-L.; Kroczak, T.; et al. DNA methylation screening of primary prostate tumors identifies SRD5A2 and CYP11A1 as candidate markers for assessing risk of biochemical recurrence. Prostate 2015, 75, 1790-1801. [CrossRef]

169. Lin, Y.-L.; Li, Y.-L.; Ma, J.-G. Aberrant Promoter Methylation of Protocadherin8 (PCDH8) in Serum is a Potential Prognostic Marker for Low Gleason Score Prostate Cancer. Med Sci. Monit. 2017, 23, 4895-4900. [CrossRef]

170. Sung, J.; Wang, Y.; Chandrasekaran, S.; Witten, D.M.; Price, N.D. Molecular signatures from omics data: From chaos to consensus. Biotechnol. J. 2012, 7, 946-957. [CrossRef]

171. Peters, T.J.; Buckley, M.J.; Statham, A.L.; Pidsley, R.; Samaras, K.; Lord, R.V.; Clark, S.J.; Molloy, P.L. De novo identification of differentially methylated regions in the human genome. Epigenetics Chromatin 2015, 8, 6. [CrossRef] [PubMed]

172. Yosefian, I.; Farkhani, E.M.; Baneshi, M.M. Application of Random Forest Survival Models to Increase Generalizability of Decision Trees: A Case Study in Acute Myocardial Infarction. Comput. Math. Methods Med. 2015, 2015, 576413. [CrossRef]

173. Liu, C.; Wang, X.; Genchev, G.Z.; Lu, H. Multi-omics facilitated variable selection in Cox-regression model for cancer prognosis prediction. Methods 2017, 124, 100-107. [CrossRef]

174. Kvamme, H.; Borgan, Ø.; Scheel, I. Time-to-Event Prediction with Neural Networks and Cox Regression. J. Mach. Learn. Res. 2019, 20,1-30.

175. Sanz, H.; Reverter, F.; Valim, C. Enhancing SVM for survival data using local invariances and weighting. BMC Bioinform. 2020, 21, 193. [CrossRef]

176. Li, J.; Xu, C.; Lee, H.J.; Ren, S.; Zi, X.; Zhang, Z.; Wang, H.; Yu, Y.; Yang, C.; Gao, X.; et al. A genomic and epigenomic atlas of prostate cancer in Asian populations. Nat. Cell Biol. 2020, 580, 93-99. [CrossRef] [PubMed]

177. González-Billalabeitia, E.; Conteduca, V.; Wetterskog, D.; Jayaram, A.; Attard, G. Circulating tumor DNA in advanced prostate cancer: Transitioning from discovery to a clinically implemented test. Prostate Cancer Prostatic Dis. 2018, 22, 195-205. [CrossRef] [PubMed]

178. Korbie, D.; Lin, E.; Wall, D.; Nair, S.S.; Stirzaker, C.; Clark, S.J.; Trau, M. Multiplex bisulfite PCR resequencing of clinical FFPE DNA. Clin. Epigenetics 2015, 7, 28. [CrossRef]

179. Lam, D.; Luu, P.-L.; Song, J.Z.; Qu, W.; Risbridger, G.P.; Lawrence, M.G.; Lu, J.; Trau, M.; Korbie, D.; Clark, S.J.; et al. Comprehensive evaluation of targeted multiplex bisulphite PCR sequencing for validation of DNA methylation biomarker panels. Clin. Epigenetics 2020, 12, 1-16. [CrossRef] 